\title{
THE ECOLOGY OF THE ANTS OF THE WELAKA RESERVE, FLORIDA \\ (Hymenoptera: Formicidae)
}

By

ARNOLD F. VAN PELT, JR.

A DISSERTATION PRESENTED TO THE GRADUATE COUNCIL OF THE UNIVERSITY OF FLORIDA

IN PARTIAL FULFILMENT OF THE REQUIREMENTS FOR THE DEGREE OF DOCTOR OF PHILOSOPHY

UNIVERSITY OF FLORIDA

September, 1950 


$$
\begin{aligned}
& 595796 \\
& 12730
\end{aligned}
$$

$$
\begin{aligned}
& \text { BIOLOGY } \\
& \text { GEOLOGY } \\
& \text { LIPRARY }
\end{aligned}
$$

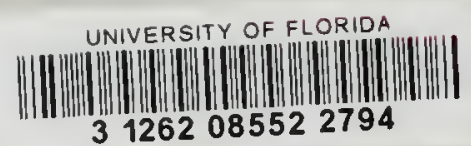




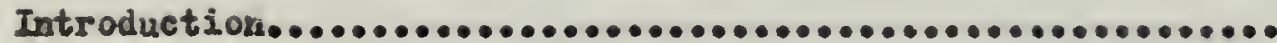

Description of the Areq..............................

Location and Physical Peatures..................

The Solis and Vogetation......................

Definitions........................................

Hothods of study....................................

Collecting Lothods and tho Recording of Date in the Field..................................

Relative Abundance..........................

The Collecting Stations of the Reserve....................

Summary of the Recognized Stations..............

Description of the stations.....................

Ioological Reletionships.............................

Description of the Strata and Nesting Sites.......

Distribution in Stations......................

Distribution in Strate and Nosting Sites..........

Activity Relationships.......................

Annotated List.......................................

Addenda..................................... 149

Summary $\ldots \ldots \ldots \ldots \ldots \ldots \ldots \ldots \ldots \ldots \ldots \ldots \ldots \ldots \ldots \ldots \ldots \ldots \ldots \ldots \ldots \ldots \ldots \ldots \ldots \ldots \quad 150$

Acknowledgmento........................... 153

Literature Gited.................................... 


\section{INTRODUCTION}

Thio disertation presents the results of a study doaling with ocological rolationships of the ants on the University of Florida Conservation Reservo, Welaka, Florida. It is an attempt to expand the knovlodge of the nesting habits and beharior of the ants of a limited area. Although eimilar studies on ants had been undertaken previousiy in other parts of the United States, especially the middle west, there atill remained the opportunity to study comprohensively an area in the southeastern Costal Plain, with its influonce from both the neotropical and nearctic fauna.

In atudying the ants of the Reserve, it was desired to 1) ascertain what ant forms occur on the Reserve, and to determine their quantitative relationshipe in each of the situations in which they are found; 2) classify these different situations from a knowlodge of the qualitative and quantitative distribution of the ants in them; 3) gather a much information as poselble concerning the life history and habitu of the ants.

During the study much interesting information incidental to the main problem was obtained on various aspects of the ants' biology. Observations concerning the speed of morement, feoding habits, guests and parasites in the nests and on the individuels, and the hours during which foraging is done are includod in the Annotated List.

The literaturo bearing on ants of selected regions has been, for the most part, liets or keys, including only notes as to the nesting habits of the ants concerned. Several recent papers hare dealt with the ecological relationships between the ants and the environment of 
limited areas: Buren (1944) in Iowa; Cole (1940) in the Great Smoky Mountains of Tennessee; Gregs (1944) in the Chicago segion; and Talbot (1934) also in the Chlcago region. Those papers dealing with Florida ants have been four state lists (Smith, 1930, 1933, 1944, and Whoeler, 1932) and a key to the ants of the Gainesville region (Van Pelt, 1948). Unt 11 rocently, the taxonorny of ants has been based on a quadrinomial syatom. About 1875. Carlo Fnery and Auguste Forel firat recognized infraspecific units. At that time the taxonomy of the Buropean ante, with which these men dealt, was in period of stability brought about by the thorough knowledge these men had of their fauna. They therefore folt no hesitation in marking forms as distinct which showed a slight variation. Species were first divided into races by Forel, and were later termed varieties by Bmery in 1885. In 1890, Emery recognized tho subspecies a a acond infrespecific category. Accoptance of this quadrinomial system was not immodiate, but through the added influence of $W$. $Y$. Wheeler, it vas in general use by 1910.

Even though Forel in his Fourmis de le Suisse recognized the possibility that aubspecies intergrade and exiat in separate ranges, the concept was embryonic and he failed to carry through with 1t. Moat other authors disregarded this geographical aspect of aubspecies, and named the infraspecific forms on the basis of their concept of the magnitude of the difference botween them. Thus subspecies were separated by smaller differences than species, but by lerger ones than varieties. Lost of the matorial studied by Emery and Forel consisted of cabinet specimons. Lack of auficient field observation and data, such as this dissertation presents, led them into making taxonomic errors. 
quadrinomial system. Wheoler, in 1910, in his book Ants, suggested that the variety in ant nomenclature is very nearly equivalent to the species in other groups, such as birds and mammals, and that for ordinary purposes it would be cufficient to treat the rarietal name as if it were spocific. In vriting generally of an ant, therefore, he used a binomial system, but retained the full terminology for catalogue listings and the like. The efforts of wheoler and other authors who were tending away from quadrinomial nomenclature might have produced more general results if it had not been for the publication, from 1901 to 1925, of Bmery's soction on the Formicidae in the Genere Insectorum, with its concomitant authority. In 1938 Creighton proposed a trinomial oystem in which all of the varieties were to be raised to subspecific rank, and in 1944 Buren put this idea into practice for the ants of Iowa. Finally, in 1950, Creighton published anual on the ants of North America in which he revised his arlier concept by discarding the category "variety", and by designating as subspecies all intergrading forms which replace each other geographically. Actually a grot many varieties were relegated to synonymy because the characters, epocially color, separating them from their most closely related forms, were found to be invalid. Most of Creighton's changes involved either synonymizing varietios or raising them to subspecific rank. His paper ought to have a wide influence in placing ant nomenelature on a sound basis. Several points in the present study have been simplified, and other obvious mistakes in provious nomenclature rectified by accopting his trinomial systom.

Literature references are given at the ond of this dissertation only for those pepers cited in the text. No references to original 
descriptions or to papors dealing with synonomy are listed. The reador mill be able to find these roferences, along with keys to all North American ants, in Creighton (1950). 


\section{DESCRIPTION OF THE AREA \\ Locetion and Physical Features}

The University of Floride Conservation Reserve, where the prosent study was made, is a 2180 acre trect, located on the cast bank of the St. Johns River, about sorentoon miles south of Palatka neer the town of Wolaka in Putnam County, Florida. The Reserve is situated in northeastern peninsular Florida on a portion of the state known as the Coastal Lowlands (Cooke, 194588), and is for the most part located on the Pamlico marino terrace, which is designatod by its 25 foot elevation above sea level. It is approximately in the conter of the rectangle formed by the Iines of latitude of $29^{\circ}$ and $30^{\circ}$, and those of longitude of $81^{\circ}$ and $82^{\circ}$.

The Roservo varies in its topography from flat or very gently rolling lands covered with pine woods to hilly uplands supporting oak and pine, and many areas are pock-marked because of the solution of the underlying limestone. The uplands, with their sand duno appearance, are eridence that the land was once part of a marine shore 1ine. The submergences and energences of the Coastal Lovlands to form Ploletocene marine terraces, alons with the absonce of catastrophic movements in the Wolaka area, as well as in all Florida, will undoubtedly prove important in consideration of the zoogeographic distribution of the Formicidae. For a complete discusaion of the geology of this area, as woll as other parts of Florida, seo Cooke (1945).

Usually more than half of the annual precipitation falls in thunder showers during the hottest months, June to September, when rainfall averages 5 to 10 inches per month. Least precipitation occurs in late fall and again in early spring, with a monthly average of 1 to 4 inches. 
The annual rainfall averages under 50 inches. The weather station at Crescent $\mathrm{City}^{1}$ recorded the total precipitation per month during the period of the present study as shown in Figure 1. Tor complete data on the climate of Florida from 2896 to 1926, see Mitchell and Ensign (2928).

The temperature of the are in which the Reserve is located arerages about $70^{\circ}$ Fahrenheit. Freezing temperatures ocy ocur from November to Larch, although frost-free winters have been roported. Sumer temperatures average $80^{\circ}$ to $90^{\circ}$, and are at times recorded abovo $100^{\circ}$. Temperatures may vary greatly within a small area, for example, from a dense harmocis to an open flatwoods. Figure 1 shows the averago monthly temperature during the period of the present study. The average length of the growing season is 300 days. The first killing frost in fall may occur in Norember or December; the last killing frost in spring usually occurs in February or llarch.

The nearest weather station recording relative humidity is at Jacksonville, where the mean annual relative humidity for 7 A.L. Is 83\%, while for 7 P.ll. it is 76\%. Records from here also indicate only the goneral conditions on the Reserve, since Jacksonville and Welaka are soparated by sevonty miles. Moreover, relative humidity varies greatly within a ll area, depending upon tho regetational conditions oncountered. Tho author has recorded relative humidity below $20 \%$ on numerous occasions in open areas on hot, sunny days.

1 The records of temperature and rainfall taken from Crescent City, - leven miles to the east, can be used only as general indications of conditions on the Reservo. 


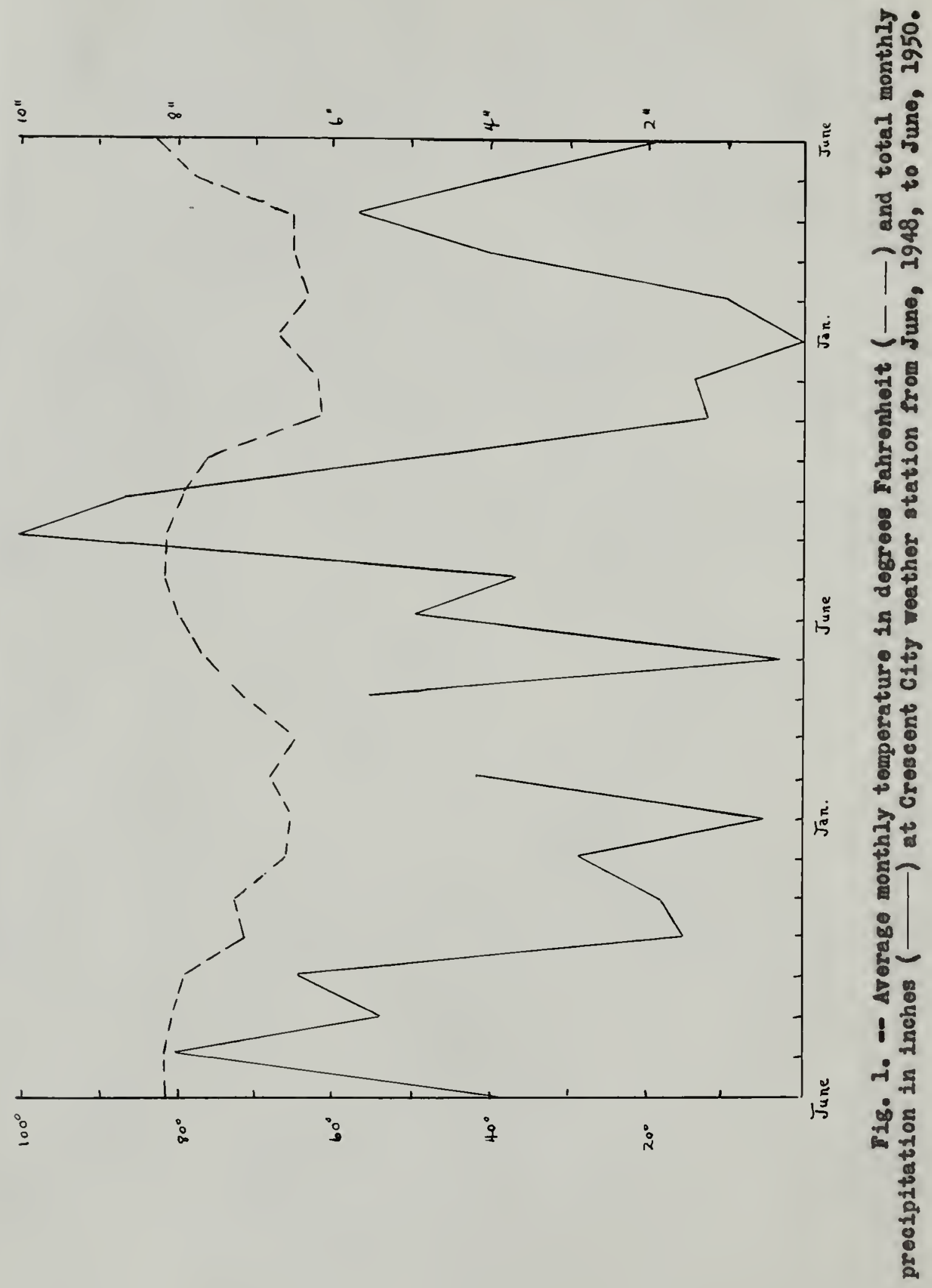




\section{The Soils and Vegetation}

During the surmer of 1948, a soll survey of the Reserve was made in order to become acquainted with the soil types present. This work was based to a great axtent on the detailed survery of the area made by Laessle (1942). Whore nocessary, the ooil-type nomenclature was brought up to date (See lap 1). The following discussion of the derivation and texture of parent materials, and of drainage, is bered on Laessle's paper.

The mineral soils of the area are very probably derived from warine dopogits of fine sand. No clays were found within six feot of the ourface, with the exception of small areas along the St. Johns River. The organic soil, poety muck, has boen laid dom by the aocumulation of vogetable matter in two extensive areas along the river.

Chemical analysio of the ooils has boen carried out only to a minor extent in nearby areas, and not at all on the Reserve.

In the rolling areas, and in othor areas where the land is not ontirely plat, the very sandy nature of the soll permits excellent drainage. Iuch of the Reserve, howerer, is almost completely Plat, and in these areas lateral movement of water is slow or negligiblo and the water table is near the surface. In my of the flat areas, an accumulation of organic matter, called a hardpan, is lormed at varying depths benoath the surface, and in such areas during hoavy rains the ground becomes superseturated. In lower positions within the flatwoods, organic matter accumalates as a black or dark gray layer at the surface rather then as a hardpan. In contradistinction to these s0118, the ooils of the higher ares, with good interral drainage, do not have an organic hardpan within 42 inches of the surface and contain very little organic 
Nap 1: Soil Map of the Roserve

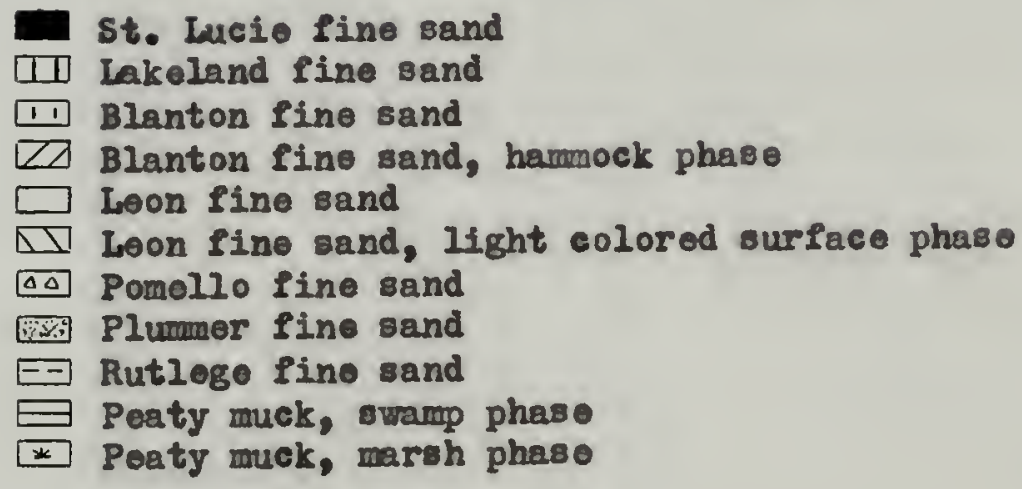




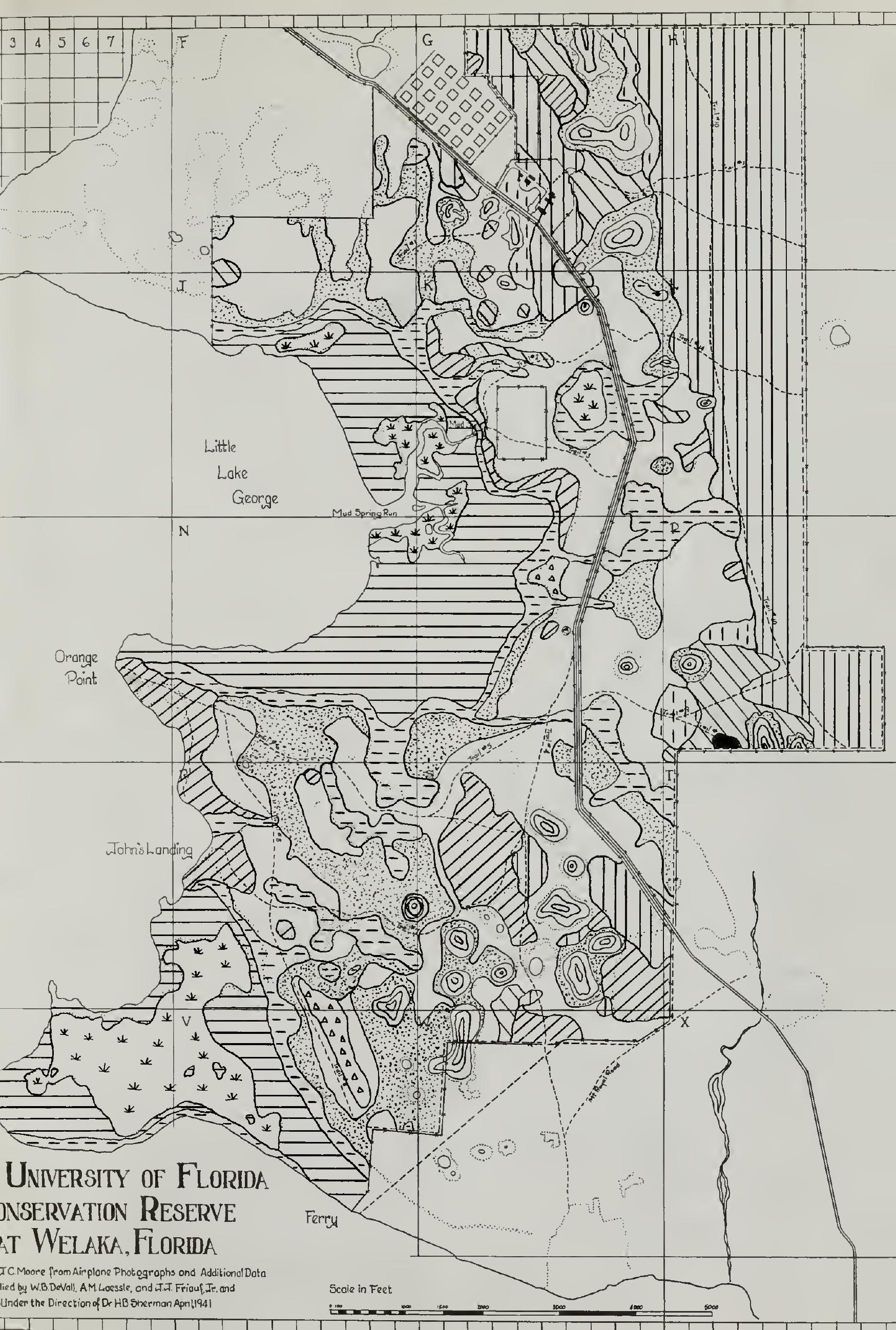


matter in the surface soil.

The regetation of the Reserve (Iap 2) may bo divided into four main catogories, not including the various types of ruderal areas. They ares 1) uplande or sandhills; 2) Nlatwoods; 3) hammocks and 4) seasonally flooded areas. On the eastern side of the Reserve there is a large arou of uplands supporting longleaf pine and turkey oak, and scattered in the southern portion aro similar smallor areas coverod with longleaf pine and bluejack ark. Various types of llatwoods form a strip, interrupted by bayheads and highor hamocks, through the conter of the Reservo. Low hamnooks form a strip adjacent to river swamp and marsh which border the St. Johns Rirer. 


\section{VEGETATION MAP of the}

UNIV. of FLORIDA CONSERVATION RESERYE, WELAKA, FLA.

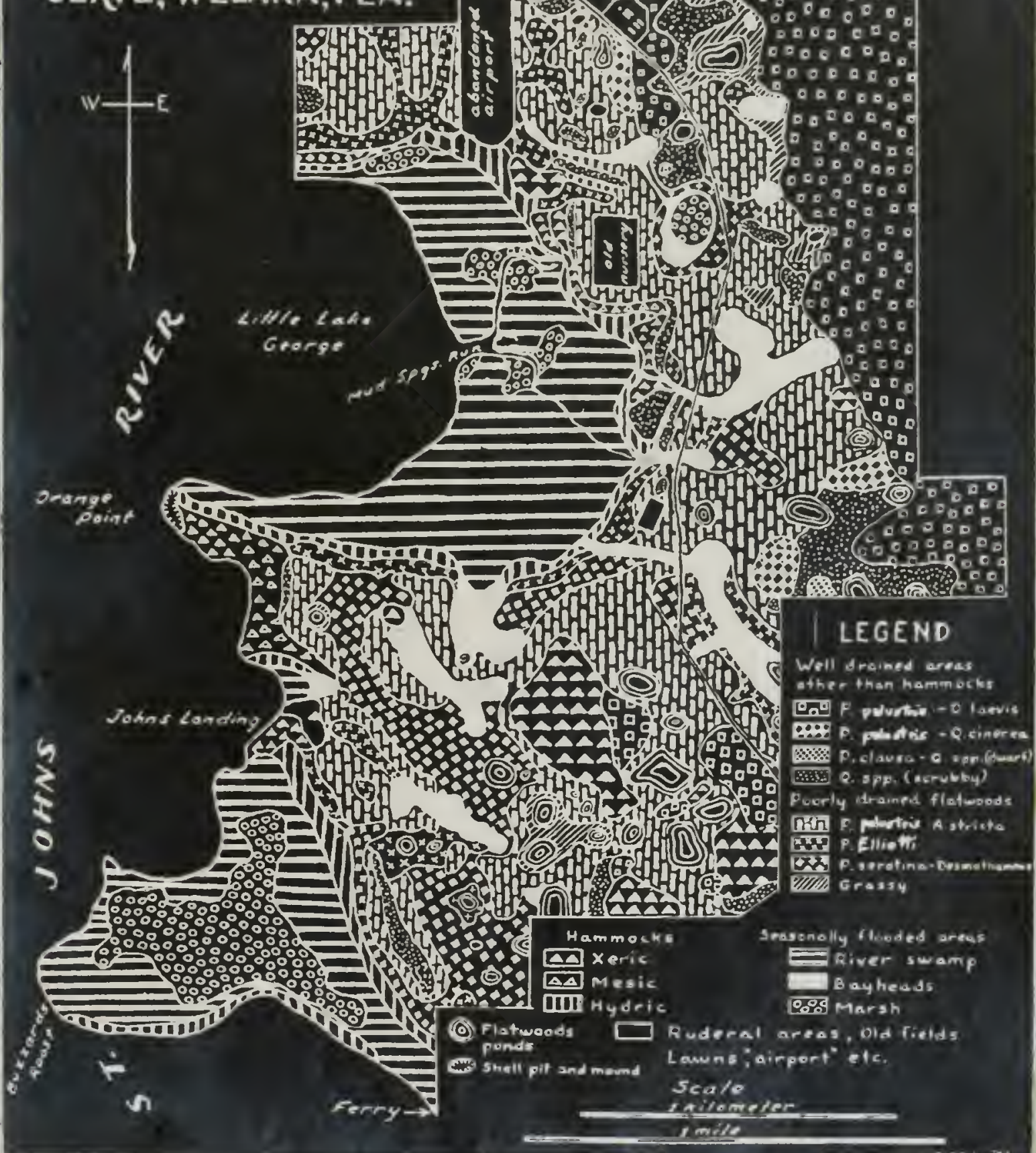




\section{DEFINITIONS}

The following definitions of term are given so that their use in the remainder of the dissertation will bo clears Form - Ant form is usod to designate any category below subgemus. Assemblage or species agsemblage - Assomblago is used to designate a characteristic and distinctive aggregate of ant colonios containod in a given plant association, stratum, or nesting site. Such an assomhlago can be separeted quelitatively and/or quantitativoly from any other assemblage. In this dis sertation all assomblages contain more than one species, and are consequently species assemblagos.

Habitat -. The environment in which an asgomblago occurs is its habitat, and consequently the habitat of all the ant forms within the assorblege. Stratum - A stratum is ono of the vortical levels or layors within plant asociations. As used here, it is not delimited by the boundaries of any one plant association or station, but extends through all of ther on the Ree erve. Nesting gite - Nest is used to designate the place in which ore colony Iives, whereas nosting site indicates all nesting places of similar structuro and composition, regardless of plant association boundaries. A11 nests in stumps, for example, are in one nosting site. Relative abundanco - The torm relative abundanco is used as a measure to indicate the density or abundance of one form in a collecting station during a particular time relative to the abundance of any form in any ctation over an equal longth of time. It is besed on colonies, not individuals. Station - An ara chosen as representative of a plant association. Collection - Applied to each nost observed or collected. In cases where only wandoring individus Is Eere seen, they rore recorded as a collection on the supposition that a nost wapearby this applied in most instances to rare ants whose rasting sites vere not known. 


\section{IRTHODS OF STUDY}

Many authors have found close correlation between the distribution of the animals they studied and plant associations. On this basis they have been able to designate plant associations as the habitats of distinctive epecies aseemblages. On the other hand, there are found to be other assemblages associated with strata. These strata may bo confined to only one plant association, or they mey extend through several. They have also been considered habitats. Thus an ecological hierarchy was set up with the plant associations as major habitats, and strats as minor habitats.

In order to determine if oimilar relationshipo could be expressed for the ants of the Reserve, it was first necessary to wake the work on ante as comparable as possible with the work on solitary animalo. It must be decided whether the ant individual or its colony will be used as the biotic unit in dealing with distribution and relative abundance. In this study the colony in its nest, and not its individuals or their range of foraging, is considered the unit.

Among the chief reasons for basing the study on the colony rather then on the individual worker ent is that reproduction for the whole colony is generally accomplished by the queen. In this respect the workers and soldlers are not complete individuals, but generally must depend on the reproductive caste to continue the race. Food is brought back to the nest by foragere, not for their benefit alone, but for the benefit of the colony. There is cooperation among the ants of a colony, whereas there is competition among solitary animals of the same and different races, and likewise among ant colonies of tho same and of different races. In so far as the processes of living and perpetuating 
the race are concerned, the colony is more complete than the individual. It is, for example, more complete than the queen, wich might be suggested as the type of individual in the ant nest most olosely resembling a solitary animal. Using the colony as a basis, therofore, it was proposed to determine if distinctive ant assemblages existed, and if 80 , by what means they could be derined.

In order to delimit ant assemblages, it was not only necessary to discover in what eituations the ant forms occurred, but it was also necesary to determine as nearly as practicable the relative abundance of each form in each situation. So that this could bo accomplishod, it was proposed to visit plant associations (as modified in tho following section) since, 1) they occur in repeated, rather uniform stands characteristic of the Welaka area, and consequently are more readily recognizable by other workers; and 2) other workers in the Welaka area and elsewhere have found plant assoclations to be habitats for their groups. If a corrolation of plant associations and ant assemblages were found to exist, then the plant associations could be called ant habitats. If ant assemblages vere found to exist in strata and in nesting sites, these too could be considered ant habitats.

It could be postulated that soils, as well as vegetation, might be a critical factor in determining where an ant form might nest. In reslity, some plant associations occurred on tro or more different soil types so that it was to the point to combine soil type with vegetation for the purpose of selecting a collecting site. All such combinations on the Reserve wore designated as possible collecting localities. Several combinations were found to occupy an insignificant area and vere omitted. Within each of the other soil type-plant association combinations a representative area or station was selected. 


\section{Collecting Wothods and the Recording of Date in the Field}

It was known from previous exporience that ants as a family are able to live in a wide variety of nesting places, although certain ant forms aro quite specific in their requirements. Without a fairly complete knowledge of the ants to be derlt with, the data, especially as concerns relative abundence, could very well be invalidated. It was imperative, therefore, to become acqualntod as quickly as possiblo with the nesting havits of the ants on the Reserve, and likewise to become familiar with the plasts and terrain involved.

In order to facilitate progress along this line, a preliminary survey of the ants of the Reservo was begun in October, 1947, and was carried on during weokend trips from the University in Gainesville. on June 18, 1948, residence was established on the Reserve, and conceritrated collecting was begun and continued in the desner described below for somewhat over one year. The data from further collecting, carried on until Juno, 1950, wero used to substantiate tho distribution and relative abundance figures already obtained. During the period of concentrated collecting, observations were on 3576 nests.

Iach atation was visited 17 times (with additional special trips to col.lect one particular ant form or one particular nesting site). Visits to ach station wore made as nearly as possible once overy month. They were continued up to (and, in reality, past) the point at which it was folt an accurate sample had beon obtained, i.e., the point of diminishing returns. Equal lengths of time, from $21 / 2$ to 3 hours, wero spent at oach station. In order to obtain a representative sample from each station, each typo of nosting site was worked for a period of time proportionate to its abundanco in that particular station. For example, 
in longleaf pino flatwoods thero is moro opportunity for ants to nest in the beses of trees than in the opon and, and therefore the former was collected proportionatoly longer than the latter in that association. Ilost of the collections were made by forceps, and some were made with an aspirator. Tho daily oollection from oach station was supplemented by putting the litter from approximaly two square foet of soil surface through a Berlese funnel. The litter was left on the funnel with no external heat for two or throe days until dry.

To sample the contents of the litter in the field, several other Berlese-type funnels were built from five-gallon lard cans. The funnel itself consisted of an inverted light refloctor which led to a. hole in the bottom of the can; over the light reflector different roosh screening or hardware cloth could be placed. To activate the animals a few drops of household amonia were introduced, and the top placed on the can. Such funnels were left an hour or less. Another supplomentary Berlose-type funnel was made from 2 household funnol by fastening wire scroen over its top and running a rubber tube from its botton into a vial. Small pieces of wood, pieces of moss, and other similar objects rore placed on this funnel, and a light bulb, ususlly sixty watts, was lowerod in a rofloctor over the funnel. Other special collecting was accomplished by use of molasses traps, and a light trap. The ants from these last two funnels, and from the traps were not figured in the rolative abundance. For each colony collocted, the blanks on a fleld data sheet (Fig. 2) were filled in, except when two or more collections of the same form vere made in identical situations. In these cases, only ono field date shoot was filled in, but tho appropriate rolative abundance 
University of Florida Conservation Reservo, Welaka (except as noted) $1948-1950$

Det. by AVP

Coll. Ho. Go11. by ATP

Station: Ina I2a I3a I4b I4d IIIa II2a II2b IIJa IIIla III2a IIIBa IV La IV2a IV3a

Arees not on Reserve:

Foreops Berlese Seen Trap:

Nesting sites:

A. Under soil surface

1. Open sand

a. Ho crater

b. Rudimentary crater

c. Incouplete crater

d. Complete crater

2. In and under litter

3. Under log (sp.; docay)

4. Under and in $\log$ (sp.; decay)

B. On soil surface

5. In fallen log (ap.;decay)

6. In palmotto log on ground (Bp.;decay)

7. In living palmetto root/trunk (sp.)

8. In dead stump (sp.jdecry)

9. In base of living tree (op.)

10. In litter

C. Grass

11. In baso of grass elump (sp.)

12. Between agrgrass blades

13. In tall grass otea (sp.)

D. Arboreal

14. Twif (with only centor wood absent) (sp.)

15. Smil branch (with many passageways) (sp.)

16. GaII (sp. ssp. troo)

F. Other (where found)

F. Wandering

Characteristics of nest: In shade In sun Diameter of nest:

Height of nests No. openingss

Forms present: Nales Fomalos Callows Eggs Larveo Pupaes

Queon(s) Wale Femalo Worker

Coumensels (ap.)

Local abundancer abundant common occasional raro

Amount of activitys very considerable oonsiderable moderate $810 \mathrm{~W}$ no movement

Phyoical factors Day Night: Rainy Orereast Cloudy Clear

Time

Rolative humidity

Disposition of collections AvP Not kopt Pinned other

Romarks: (over )

Fig. 2. - Field data shoot. 
was chockod.

Eech colloction was recordod on the field data sheot as follows: The blanke in the upper left hand corner of the field data sheat were filled in with the name of the form taken and the detorminer. In the other corner, the colloction numbor, which combined the date with the yumber of a given collection mado on that dato, was written. The stations were givon code numbers (seo p. 16) to save space and facilitate recording on this shoet and elsowhore. Tho I's indicato high areas of sandhills, scrub, or scrubby Platwoods; the II's are tho other flatwoods; the III's are the hammocks; and the IV's are tho sersonally rlooded areas. On each shoot the station collocted was encirclod. On the next line belor the 21st of stations, the means of collection mas indicated. Then the nesting site was checked, and where applicable the species of plant in which the nost was found, its state of decay, and any other pecullarities of the nest vore listed. The rest of the sheet is colf-explanatory. Remarks of various naturos pertaining to the ant in question were written on the back of the sheot.

\section{Rolative Abundance}

If on one collecting trip of two and one-half hours to a given station an ant form tras collocted six times or more, it was considered abundant; if collected four or five tines, canton; two or three times, occasional; and if collected only once, it was treated as rare in that locality. The relative abundenco date for eaoh collecting trip was recorded in the field.

A form collected only once or twice in a given day may have a sporadic occurrence in the areo of the station collected, and yot have a relatively high abundance over a poriod of time in that station. 
Because of such possible discrepancies, a relative abundance figure based on the 17 collecting trips was complied for each form in each station so as to give a truer representation. On this basis, a form is considered abundant if it was collected in a station forty times or mores common, if collected thirteen to thirty-nine times; occasional, if collected two to twelve times; and rare if collected once. 
COLHCTIKG STATIONS ON THE RESERVE

\section{Summary of Recognizod Stations}

For convenience in referring to the field deta sheot, the plant association-sojl typo combinations, or stations, are exprossod by letters and numbers roprosenting the dreinago, vegetation, and soil type of the station. For examplo, Ila represents a well dreined otation supporting the Pinus palustris-Quercus leovis association on Lakeland fine sand. The stations chosen ares

I. Well drained areas other than hamecks

1. Pinus palugtris-Quercus laevis association

a. Lakeland fine sand (Turkey oak sandhilis or uplands)

2. P. poluetris-Q. cineres ass.

a. Blanton f. . (Bluejack dak sandhilis)

3. P. clausg-Q. Virginiana var. geninata-2. mertifolia9. chapmanif asa.

a. St. Luoie f. s. (St. Lucie всrub or всrub)

4. Q. virginiana var. geminata-Q mrtifolia-9. chapmanii ass.

b. Leon $f . s .$, light colored surface phase (Loon scrubby flatwoods)

d. Pomello f. s. (Pomello serubby Ilatwoods)

II. Poorly drained flatwoode

1. P. palustris-Aristida stricta as8.

a. Leon f. s. (Longleaf pine flatroods)

2. P. elliotti ass.

a. Plumer f. 8. (Plumer slash pino rlatwoods)

b. Rutloge P. B. (Rutlog $\theta$ lash pine Platroods) 
Lap 33 Distribution of Stations on the Reserve.

Ila. Turkey osk sendhills or uplands I2a. Bluejack ook sandhills

23a. St. Lucio scrub or scrub

I4b. Leon scrubby llatwoods

I4d. Pomello scrubby flatwoods

IIla. Longleaf pine flatwoods

II2a. Plumer slash pino flatwoods

II2b. Rutloge slosh pine flatwoods

II3a. Black pine-fetterbush flatwoods

IIIls. Xeric harmock

III2a. Nesic hammock

III3a. Hydric hammock

IVla. River swamp

IV 22. Bayhead

IV3a. Marsh 
3. P. serotina-Desmothamnus as\$.

a. Plumer f. s. (Black pine-fotterbush flatroods)

III. Hamocks (Fell drained to nearly saturatod)

1. Q. Virginirna ass.

8. Blanton f. S., hamock phaco (Xoric harmock)

2. Magnolia grandiflora-IIex opaca ass.

a. Blantion f. פ., hamock phase (Mesic harmock)

3. Q. nisre-Liquidambar-Sabal peimotto as .

2. Rutloge f. 8. (Hydric hammock)

IV. Sorsonally flooded areas

1. Taxodium distichum- Nyrse biflore ass.

a. Peaty muck (Rivor swamp)

2. Gordonia-Tamala pubescens-Nagnolia virginiana ass.

a. Rutlege f. s. (Bayherd)

3. Mariscus jamiconsis ass.

a. Peaty muck (Larsh)

Descriptions of the Stations ${ }^{I}$

Turkey oak sandhills

(P. pelustris $-Q$. lsevis ass.; Lakeland f.8.)

Tho location of this station (seo lap 3) is in the northeast portion of the Reserve, between Trailo 10, 11, and 12. Characteristic trees are the longlear pino (P. palustrig ${ }^{2}$ ) and turkey ak (Quercus laevis).

1 For a fuller discussion of the vegetation and soils of the Reserve as a Whole, and of the stations mentioned here, the reader should 300 Laessle (1942). 2 The ecientific names of pines are taken from West and Arnold (1946). 
Bluojack oak (Q. cinorea) and livo oak (E. virginiana) are also present, but are not so plontiful. Bolow the widely spaced trees is a scanty horbaceous veretation consisting in the main of viregrassos (Aristida stricta and Sporobjlis gracilis). Between those rather dense patchos of viregrass there are areas of bare, pale gray sand.

Lakeland fine sand (Laesslo's Norfolk fine sand, decp phase) ray occur on level or gently loping areas of uplands, but on the Reservo it appears chiorly in tho rolling turkey oak sandhills. The soil has good drainage, but it so not as excossive as that of St. Iucie fine sand and lakewood fine sand. It has more organic matter in the ourface layer than eithor of the latter soils.

Bluojack oak sandhills

(P. Dglustris-2. cinorea ass.; Blanton $f_{0} \varepsilon_{\bullet}$ )

This station is locatod at the junction of Trails 9 and 13 in the middle of the esstorn side of the Reserve. The vegetation is similer to that of the turkey oak sandhilis, oxcopt that bluojsck oak (Q. cinerea) is the codominant instead of turkey oak. The pines of this otation are larger and more mumerous in a given area than in the turkey oak sandhills, and there is consequently more pine neodle litter. This litter, along with the wiregrass and the littor addod by the oaks, forms a complete and sometimes denso at.

Blanton fino sand possesses good to fair drainage. Although the soil has no organic hardpan, thore is a tendency towerd one at a depth of three foot where the soil. borders Loon fine sand. 


\section{St. Lucio Scrub \\ (P. Llqusg-2. spp. ass.; St. Lueie f. •.)}

Tho area choson for this station is located just over tho Reservo fence at the end of Trail 13. Part of this area of scrub extends onto the Reserve east of Trail 13, but the larger area over the fence was chosen as more typical.

Laos so points out that tho patch of scrub in question lacks certain characteristic plants of tho Ilorida scrub in general. Important anons those ero rosemary (Coratiola oricoidos) and the emaphore cactus (Opuntia austring). A rathor denso growth of sand pino (P. clausa) makes up the upper story of tho station, while corub oaks, along with several other shrubs, comprise a lowor layer. Anong the oaks way bo Iistod twin live oak (G. Yirsiniana var. geminstg) and Chapnan's oak Q. chapmanii) whilo staggerbush (Xolisma forrugines), saw palmetto (Seronos repens), silk bay (Tamalg humilis), and specios of Ilex aro other shrubs found at the station. A few vines and herbs, along with mosses and lichens aro 3 is 0 to bo found. It is pointed out by laesslo (1742:29) that "In spite of the xeromorphic nature of the scrub rogetation, with its small, hoavily cutinizod, often rovolute, and hairy leaves.... comparatively uesic conditions are found...." in scrub becuuse of the close, I0w, and consequontly deaso growth. st. Wucie fine sand is characteristic of higher areas where drainago is excossivo or noarly so. Organic wattor has opportunity to romain only in the first inch of tho profile. Bolow this the raimuter louches it rapidly throuch tho large particles of what perhapo vere ancient dune sands, to give a looso, white sand. 


\section{Leon scrubby flatwoods}

(B. spp. ass.; Json f. $\Sigma$., Iight colored aurfece phase)

This station is located botween Trails 9 and 13 in the middie portion of the eastern side of the Reservo. The vegetation is like that of the st. Lucio scrub, cxcept that the sand pine and the silk bay, as voll as certain othor plants, are absent. A fen trees of longlear pino may bo presont as relics.

Leon fine sand, light colored surface phase (Laess10's Loon fino sand, scrubby phase) holds a position botween Pomello fine sand and St. Lucie fine sand on the one hand, and the typicall Loon fine sand on the other. It is better drainod than tho latter and more poorly drained than the former. The hardpan is usually within thirty to forty-two inchos of the light gray or almost vhite surface.

\section{Pomello scrubby Platwoods}

\section{(Q. врp. ass.; Pomello f. 8. )}

The patch of this scrubby flatwoodo studied is locatod one hundred yarde west of tho highway, and about $1 / 4$ wile northwest of the fire tower. The vegetation is very much 11 ke that of the Leon scrubby flatwoods. Inesslo $(1942830)$ sums up the differences between the two 28 follows: "I am ablo to dotect no fundamental regetational difference .... except that thero is a noticeable difference in the greater height attained by the shrubs [of the Pomello soli] and tho longlesi pino always searas lacking there."

Pomel10 fine sand (Laesalo's St. Lucio fine sand, Rlat phase) is more poorly drained than St. Luoie fine sand, and botter drained than Loon fine eand. It differs from Loon fino sand, light oolored surfave phase, in drainage as noted above, and in possessing no hardpan vithin forty-two inches of the eurface. 


\section{Longloef pine flatwoode}

\section{(P. palustris-A. stricts as8.; Loon $f_{0} 8_{.}$)}

This station is located between Trail 4 and the highway, about $3 / 8$ mile from the fire tower. The vegetation is dominated by somowhat scattered, large longleaf pines; small longleaf pines are quite abundant. Saw palmetto, gallberry (Ilex glabra), and fotterbush (Desmothamnus lucidus), as well as other shrubs, are found here. The ground cover consists largely of wiregrass (A. strieta), but much indian grase (Sorghostrum secundum) is present. Since fire has beon kept out for several years now, the shrubs, espocially those mentioned above, are growing profusely, and wiregrass is being forced out.

These flatwoods, which are fire subelimax for this region, grow on Loon fine sand. It is higher than Plumer fine sand and Rutlege fine sand. The soil has a gray or salt-and-pepper surface becoming lighter down to a brownieh black hardpan consisting of fino sand particles cemented together with organic matter. Below the hardpan, at twenty-eight to thirty-four inches from the surface, the sand is only partially cemented vith organic matter, and bocomes lightor brown with dopth.

\section{Plunmer slash pino Platwoods \\ (P. elliotti ass.; Plumer f. s.)}

The location of this station is a littlo less than $1 / 4$ mile southwest of the fire tower. It supports the dominant slash pine (P. elliotti) and a few longleaf and black pines. Sar palmetto and other shrubs are present, along with severel grasses, among them Andropogon.

Plumer fine sand, found in my cases botweon longleaf pino flatwoods and the lower hydric hanmocks, is a gray to light gray soil. It contains a brosn stained fino sand, usually at about throe foot. 


\section{Rutloge Lash pine flatwoods \\ (P. elliotti ess.; Rutloge f. B.)}

This station is north of Trail 3 and just west of the highway. The regetaticn, domirated by slask fine (F. Elliotti), ard comosed of scatterod treos of longleaf pire (P. plustris) and black pino ( $P$. Berotina), is similar to that of Plumer slash pine Platroods. Its shrubs consist of lettorbush (Desmotinamins Lueidus), sav palmetto (Serenos repons), and othars. Bacauss of lack of fire, thase shrubs bave bocose donso, and are in wany placos shading out the ground Layor of short grasses.

The surface ton inches of Rutloge fine sand (Leessle's Portsmouth fine sand) contain much organic matter and are dark gray or bleck. The etation is low, and in times of heary rain the eoil may become supersaturated.

Black pino-fotterbush flatwoods

\section{(P. serotina-Desmothomnus a日8.; Plumer 1. B.)}

This station is about $1 / 4$ mile eact of the junction of Trails 6 and 8 , on the south side of Trail 6, near the middle of the west side of the Reserve. The trees of the area are widely scattered black pine (P. seroting), but thickets of fotterbush are fairly dense between the pinos. Among these thickets aro open areas with littlo or no litter in which the most important plants are the broom sedge (Andropogon) and shorter grasses. The thickets themselves are on aroes raised a for inches above the 10wer, open s0il, preaenting available space for nests when the lower areas become temporarily supersaturated during the sumer rains. 
Although the soil of this station (designated St. Johns fine sand by Laessio) may not be typical Plumer fine sand, it is placed under that heading. The lack of a hardpan within the eighteen to trenty-four inch level suggesto Plumer rather than the best alternative, Sto Johns fine sand. Over the surfaco of tho very flat area, the organic matter is tightly packed.

\section{Xeric hammock}

(Q. Virginiana ass.; Blanton $\mathrm{I} .5 .$, hamock phase)

Located in the only largo area of Iive oak on the Reserve, this station exterids between Trails 6 and 7 from near thoir junction for about a quarter of a mile. Tho dominant troe is livo oak (Q. virginiana). There are also numbors of bluojack osk (Q. cinorca) and laurel oak (Q. Iaurifolig), and some cabbage palmetto (Sabal palmetto). A fer troes of longloaf pino (P. palustris) and loblolly pino (P. taoda) aro prosent. Chapman's oak, as woll as othor shrubs, wild grapos (Vitio spp.), virginia croopor (Parthenocissus guinquefolia), and grasser of the genus Panicum make up part of the rest of the flora. Because of the wollspeced large trees, tho area is quite open, except in those clumps where acrub oaks, with other lower vegetation, have grown together to forw more or less denso thickets.

Blanton fine sand, hamock phaso, has a profile much liko that of the typical Blanton fino sand. Tho soil at this station io higher than that of the surrounding Loon fine sand flatwoods.

Hesic hammock

(Magnolia Erendiflora-Ilox opsca ass.; Blanton f. s., hamock phase) This station is next to the rivor, just south of Orange Pointo The area supports a donser growth than the xoric haumock. The top 
canopy allows comparatively littlo sunlight to filter through, and consoquently the litter is moist much of the time. Whilo it is not mature onough to roprosent a typical climax association, it doce support bull bay (llagnolia grandiflora) and American holiy (Ilex opacs), along with various largo oaks and pignut hickory (Hicoria klabre). Saw palnotto and staggorbush (Xolism ferrusinea) are abundant. Among the vinee are scuppornong (Huscading rotundifolia), Smilex benanox, and virginia crevper. Fow heris are present. As in the xeric harmock, the ooll type hero is Blanton fine sand, harmock phase.

Hydrio hammock

Q. nigra-Liquidambar-Sabel peimetto ass.; Rutloge f.8.)

The site of this station is $2 / 8$ mile wost of the junction of Trails 6 and 8 at Orange Point, botween the mesic hanmock just described and the lower river stramp. As the name of the association indicates, vater oak (Q. nigra), swootgum (Liauidamibar strraciflua), and cabbage palmotto (Sabal pelmotto) are comon. Also provalert uro swamp rod bay (Tamala pubescens) and Slorida oln (Unmus floridam). Large relic slash pires are also to bo found infrequently. Poison ivy (Toxicodendron radicans) and blasphomo vino (Sallax Laurifolig), and tho shrubs wax myrtle (Cerothamnus ceriferus) and saw paimetio are not uncomon. In a lover Layer, Osrounde spp. are to be found. The ground, which at tires becomes very vet to saturated, supports patches of sphagnum. The Rutlege fine sand is much the game as described under Rutloge olash pine flatwoods. It supports a comparatively dense growth, the top canopy of which is broken in only for plooes. 


\section{RLvor swamp}

\section{(Terodiug diftichum-linsse biffore ass.; Peaty muck)}

This station is Iocated just north of lud Springs. Dominant anone the trees which form a fairly thick canopy aro bald cypreas (Iarodive distichum), water tupolo (1vssa biflora), red maplo (Rufroor mibrum), and cebbage palmotto. Tho shrubs buttonbush (Cenhelanthus eecidentalia), Sal1x longines, and wax mystlo aro present, along with veveral vines, and only few horbs. Tho peaty muck is high in organie matorial from the decomposition of debris, and is consequently dark brown or black. There is etanding water at this station almost all ycar, except just boforo the sumer ralny season. The wator isolates humbock, formed by tho root systens of trees and raleed a foot or more abore the lowest lorel of the ground.

\section{Bayhoad}

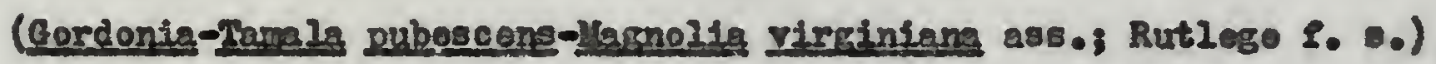

The bayhead used for this station is about $1 / 4$ mile south of tho gato to Irail 3 on tho east of tho highway. Dominant in this station aro the broadieaved overgreens, 10blolly bay (Gordonig 1agtanthus), Ewamp rad bay (Tamals aubascens), and wite bay (Magnolis virciniang). A fow ohrubs, ohiefly wax murtle, aro supported, as we11 ao blasphewe vine and poison iry. The denso canopy allows littlo herbaceous growth, but ophagnum patches oocur. Iris bayhegd is forwod in a dopression of the longleaf pine flatwoods which surrounds it. Ls Its nare suggests, bayheads hoed up inciplont otrcams whioh find thoir why to the rivor, and oonoquentIy waintain standing water at almost all easons, except porhaps just before the aumer rainy season. Cortain portions, especially toward the edge, remain comparatively dry, but the Rutlege fine sand is always moist. 


\section{Marsh}

(Yariscus jamaioensis $288 . ;$ Peaty muok)

The ares of this station is between Trails 2 and 3, near llud Springs. It supports a growth of dominant sav grass (Yariscus iamaiconsis), scattered buttonbush, and Sagittaria, along with several other smaller plants. The saw grass is in most parts of the etation so thick that not much, if any, plant life axiste besides the saw grace.

The peaty muck of this station is covered with water almost 211 year. A foot or a foot and a half of water accumulates during the sumer rainy season. Unlike the river swamp, the ground here is completely covered with water, and there are no satureted, emergent hurmocks. 


\section{BCOLOGICAL RELATIONSHIPS}

By means of repeated collecting trips to the stations, it was found that each contained a characteristic and distinctive assemblage of ant forns. Tho stations therefore represent ant habitets. It was also discovered that cortain otrata and nesting aites (as definod, p. 9) contrined distinctive assemblages. These could also then be considered ant labitate.

\section{Description of the Strata and Nesting Siteo}

The strata found to bo significant in dorignating asserablages in the present study ares 1) subsurface or subterranean; 2) surface or ground; 3) grass or horbeceous; and 4) shrub or arboreal. Inuluded in the first stratum are all those neste which occur in sand, whethor they are under logs, litter, or 8 ome othor cover, or are in the open with no cover. Nests in the surface stratum are those which occur in any of the followings litter, fallon log, palmetto root on ground, under mat of palmetto root or trunk, dead stump, base of living tree, and grass clump. Those nests which are built in and under loge are included in the stratum in which their largest portions were found. For oxample, if a colony has its largest part in a log rathor than in the sand under the log, the nest is recorded in the surface stratum. The herbaceous stratum consiste of two nesting sites, namoly, in tall grass stems (includes lariscus), and in and betwoen sawgrass blades. The ohrub or arboreal stratum includes small branches, trigi, or galls. The nesting sites recognized in these four strata are as follows: 


\section{A. Subterranean Stratum}

1. Open sand - Those nests which wero found in sand with no -over. These were divided into four types, 1) no crater -- any nest built in the open with no crater of sand pollets on the surface around the nest oponing; 2) rudimentary crater - those nosts in which a mound or string of several or wany openings was built in soemingly unorganized fashion; 3) incomplote crater -n those nests in which tho crater of cand pellots not built in a complete circle; and 4) complete crater a nest with a comploto oircle of sand pollets around tho neat opening. Incomplete craters are probebly only unfinishod complote craters.

2. In and under litter - indicates situations in which a nost may be oither in and under litter or meroly under litter. Most of the neste in this category wore actually under litter. A majority of tho nests which extended from the sand into litter were probably only in litter temporarily.

3. Under $10 g$ - those nosto in sand with the nest openings under a log.

4. Under and in 208 - those nests with portions of the colony both under loge and in logs.

B. Surface Stratum

5. In fallen logs - Includes all logs axcept those of palmotto.

6. Palmotto logs on ground -- with thoir scaly structure, offerod a distinct nesting site, which oven though rarely found was usually inhabited.

7. In living palmotto root or trunk - on living palmetto roots and on the beses of pelmetto trunks, nests occur in the dobris 
beneath the mat and betwean the bases left by fallen fronds.

8 and 9. Hests in doad stumps, and in the bark at the basog of living treeg - usually occurred in the noist first four inches abovo the soil surface.

10. In littor - those nestg built in and on fallen leaves, espocially live osk. This type of nest occurred most often in mesic hamnock on oak leares which had Illen so that the convex surface was next to the ground. The ants lived on the invorted, concevo surface, and the colony vas covered by one or more leaves. This was a favorite nosting site of Paratrechins parvula (Mayr), and although other ants, such as Pheidole dentata Mayr, vero found in it, they nested thero only 8eldom. Other nests in this category vore taken in the lower aroas of the Reserve from piles of pine needles supported by low rogetation.

11. Nests in the basos of grass clumps aro built mostly between the appressed blades of gras $s$ and in the roots. Various ants occur in this nesting site, usually in Iow areas such as Rutlego slash pino flatwoods, but again Paratreching perrula (hayr) is most abundant. Nests of this kind are especially numerous during the wet scason. Although this category was first placed in tho herbaceous stratum, its closo relation to othor nesting sites in the eurface stretur makes it necossary to place it in the latter stratum.

\section{Horbaceous Strature}

12. Botween sewrrass blados - this category is vory mach liko the lest in that the ants nest betwoon approssed blades. Whore sawgrass occurs, howevor, thore is standing water most of tho year, and nosts cannot extend into the roots. Paratrechina parvulo (Nayr) is a major inhalsitant of the sevgrass too. 
13. Iall greos stema - Lost of the tall grase in which ants 1ive is of the genue Andropogon. Othor tall gresses do not allow enough room for the ant to move within the etem. One of the fow inhabitants of the tall grass stems is Psoudomyma pellide F. Smith, but it is found there abundantly. Also included within this category are the Plower stalks of sawgrass, although the occurrence of ants within then is not great.

\section{Arboreal Stratum}

14. Irige - those branches from which the center core of wood is absent, providing only onough room for the ant to crawl through.

15. Smal1 branohes - those branches whioh have multiple passageways, or which retain only the bark and a very little of the wood. 16. Golls - Nosto in galls seem to be made only after the gall insect has emerged. The ante always use the oponing made by the emerging gall insoct as a nest opening, but some galls showed additional openings quite oridently made by the ants.

A miscellaneous category, "other", is used for nests in pine cones, fern roots, under stones, and other such places which are of little consequence for nosting on the Reserve. Availability of Nesting Sites in Stations

Table I shows the relative abundance of places to nest in the various stations. This abundance is purely subjoctive, based on the fiold experience of the author, and is used to indicate the abundance of a given place to nest in a given station relative to that of the same place in anothor station. Tho column "Litter" serves a double purposo in designating the availability of nesting pleces both in litter and in and under litter. Likewise, the column "Broadleaved or pine logs" 


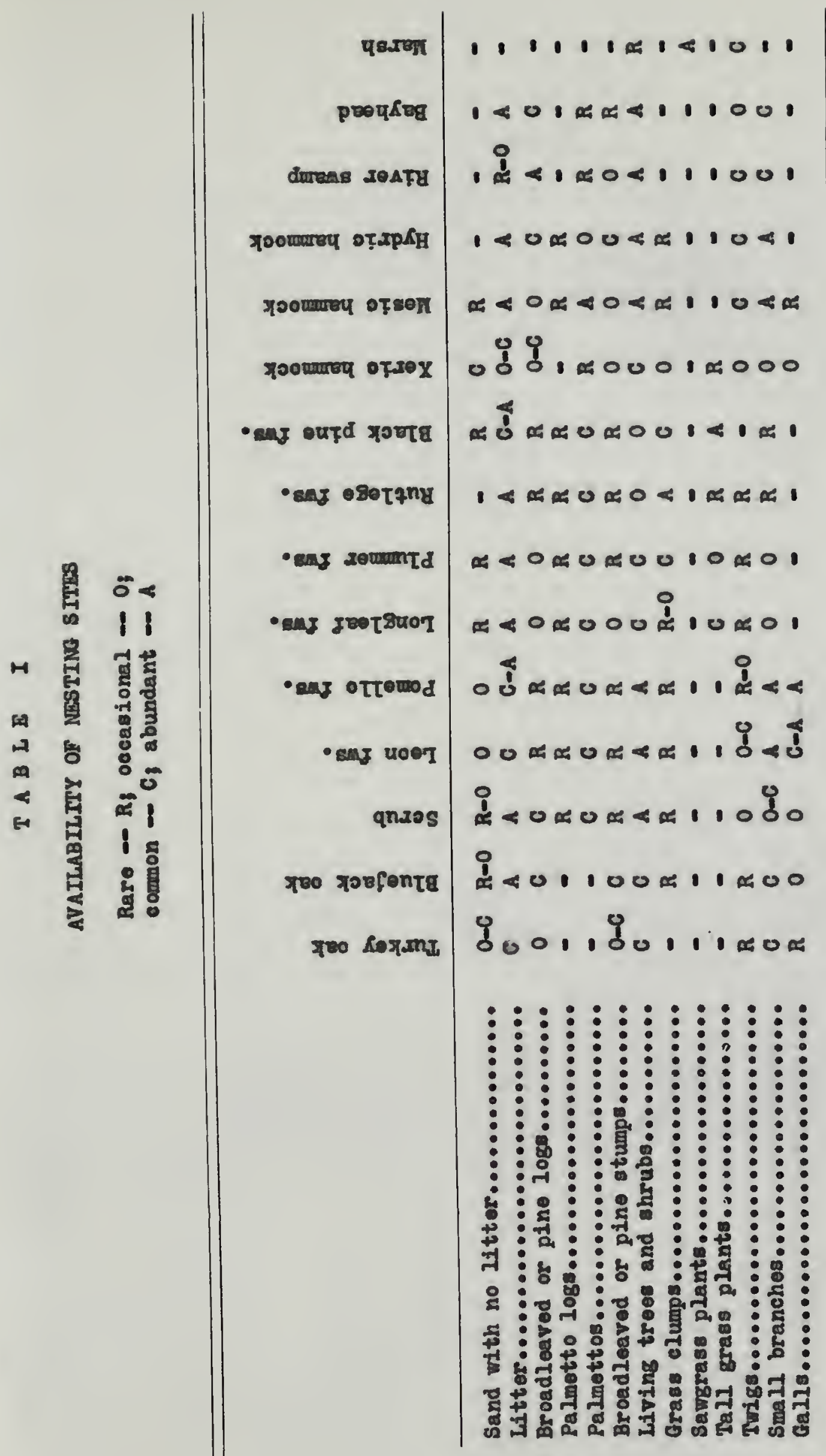


indicates tho availability of places to nost in and under logs, under logs, and in fallen logs. The table therefore indicates the availability of tho nosting sites in the stations.

In parts of hydric hamock and bayhoad, litter not only covers the whole surface area, but it is also thick, sometimes reaching a depth of 8 ix inchos or more. Ants that lived under litter were found to bo at a minimum, being replacod by ants living in litter and in tho mazo of roots and docaying logs buried in litter. Litter io common or abundant in almost evory station except swamp and marsh. Hero the availability of nesting sites in litter is cut down by the seasonally standing water. In stations such as xeric harmock and turkey oak, where the tree, shrub, and herb growth is widely spaced, large patches of bare sand are present. Logs are not abundant on the Reserve, except in hydric hanenock and river swamp, because of the logging operations being carried on. In the swamp, however, most of the logs are under water for the best part of the year, and consequently offer no nesting places. The column "Living troes and shrubs" indicates the abundance of the possible nesting places in the basos of trees and shrubs. Nesting sites are found almost always in the bases of pine treos, rather than in the beses of broedleavod troes.

"Grass clumps" shows the abundance of elumps of grass, including the bases of the tell grassos. "Tall grass plants" denotes Andropogon. The stows, in which tho ants live, die in the winter, and although some remin suitable for nesting sites throughout the year, there is a tendency for this nosting site to disappear soasonally. 


\section{Distribution of Ant Forms in Stations}

Tablo II shows the distribution of ant fornas in stations on the Roservo. In general, they preferred the higher and more opon areas in which to nest. Xoric hamock and turkoy oak contained the largest number of forms with 43 and 42 respoctively. The next 11 stations held smaller and smaller numbers of form, the numbers diminishing by one to three per station. The black pine-fetterbush flatwoods supported only 17 forms, and the number dropped to 21 in marsh. The number of forms por station is as follows

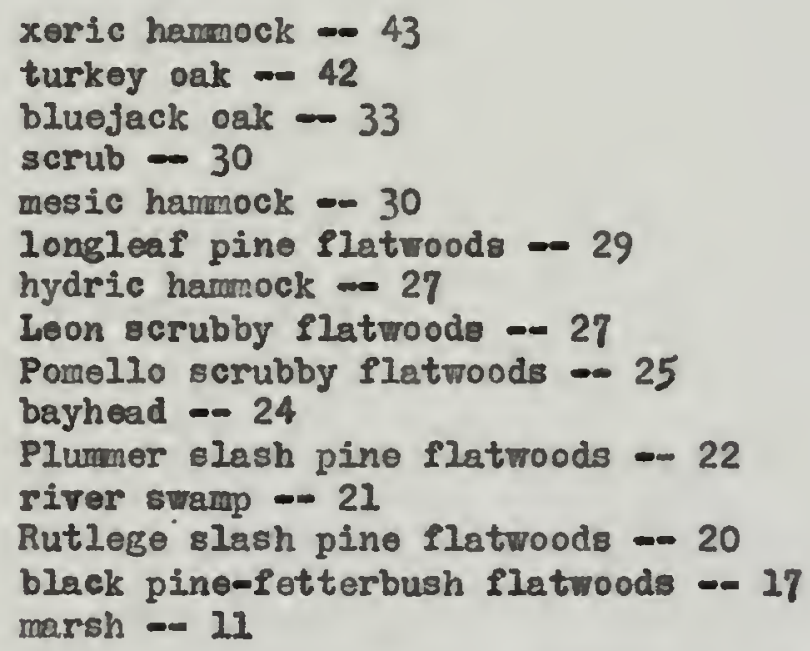

The mean number of forms collected in one station is 26.7 , a figure lying betwoen hydric hamrock or Leon scrubby Platwoods and Porallo scrubby flatwoods, noar the middle of the list.

The difference of 9 forms between the first two stations and the next highest probably indicates an aspect of the unnaturalness of the Reserve. Where there should be logs undor what are natural conditions in other portions of the state, the timber has boon removed on the Reserve before it fell. Longleaf pine flatwoods and mesic hamock should contain more fallen logs than they do, with a correspondingly greater number of log-inhabiting forms. In Gainesville, a more typical mesic hamock, 


\begin{tabular}{|c|c|c|c|c|c|c|c|c|c|c|c|c|c|c|c|c|c|c|c|}
\hline पहल. & I & 1 & 1 & I & 1 & ! & 1 & 4 & 1 & 1 & 0 & & I & 1 & 10 & & 1 & & 1 \\
\hline реочरвв & I & 1 & 車 & 1 & I & 1 & 1 & $\propto$ & & ט & $\infty$ & 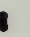 & 1 & 番 & 16 & 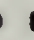 & 1 & 1 & I \\
\hline inrens $20 \triangle T \mathrm{~T}$ & 1 & 1 & 1 & 1 & 1 & ! & 1 & 0 & 1 & 0 & 0 & & 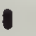 & 1 & 18 & 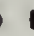 & 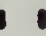 & 0 & 1 \\
\hline 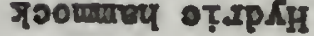 & 1 & 1 & 1 & I & 1 & O & 0 & 0 & 0 & v & 0 & 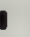 & 1 & 1 & 10 & & 1 & 1 & 1 \\
\hline 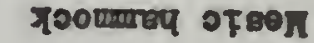 & 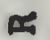 & 1 & 1 & 1 & - & 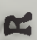 & 0 & 1 & 0 & 4 & 0 & 1 & 1 & 0 & 1 & 1 & 1 & ar & 1 \\
\hline 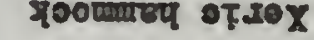 & 1 & 1 & 1 & 1 & e & I & 1 & 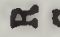 & 0 & 0 & c & & 3 & 0 & 10 & a & 1 & 車 & 1 \\
\hline ang outd भoषT\& & 1 & I & 1 & 1 & 1 & D & $\infty$ & if & $\approx$ & 4 & 1 & 4 & 1 & 1 & 1 & & 1 & 1 & 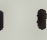 \\
\hline - enz 080t7ng & 1 & 1 & D & - & 1 & I & 1 & $<6$ & بُ & 0 & cer & ? & - & - & $1 \mathrm{c}$ & & c & । & 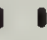 \\
\hline - sen sewrontd & I & I & 1 & 1 & 舟 & 1 & 1 & I & 0 & 0 & 10 & o & 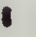 & 1 & 1 & & 1 & I & 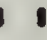 \\
\hline - sue ze0tsuot & 1 & 0 & - & 0 & 1 & 1 & 1 & 16 & 幽 & 0 & & 3 & ? & 1 & 16 & & 0 & $\infty$ & 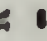 \\
\hline - SAL OTTOEOd & 1 & 1 & 1 & 1 & 1 & 1 & 1 & 1 & 1 & o & 0 & 1 & 8 & 1 & 1 & & 1 & 1 & 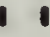 \\
\hline - ginf uoor & 1 & 1 & 1 & 1 & 1 & 1 & 1 & 1 & 0 & 0 & 0 & ט & 1 & o & 1 & & 1 & & 0 \\
\hline quxos & 1 & 1 & 1 & - & 1 & 1 & I & 10 & 0 & o & 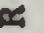 & 1 & 8 & 0 & $1 c$ & & 1 & & 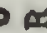 \\
\hline गеo मेefont8 & 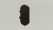 & 1 & 1 & بs & 1 & 1 & $\infty$ & 18 & 0 & 0 & & o & 0 & o & 1 & & 0 & 1 & 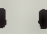 \\
\hline
\end{tabular}

畓

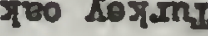

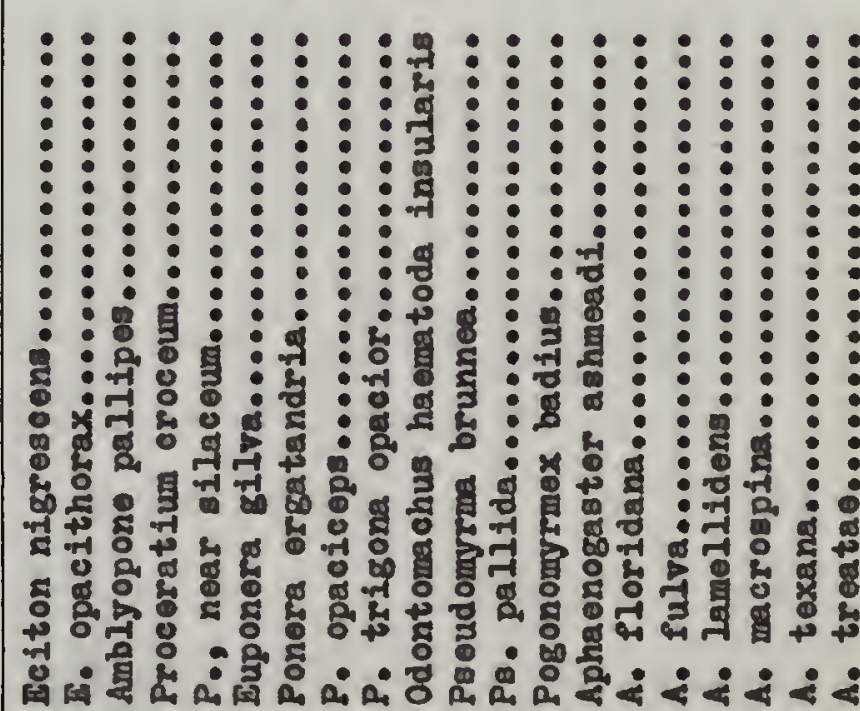

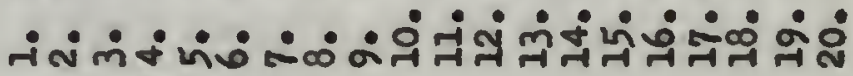




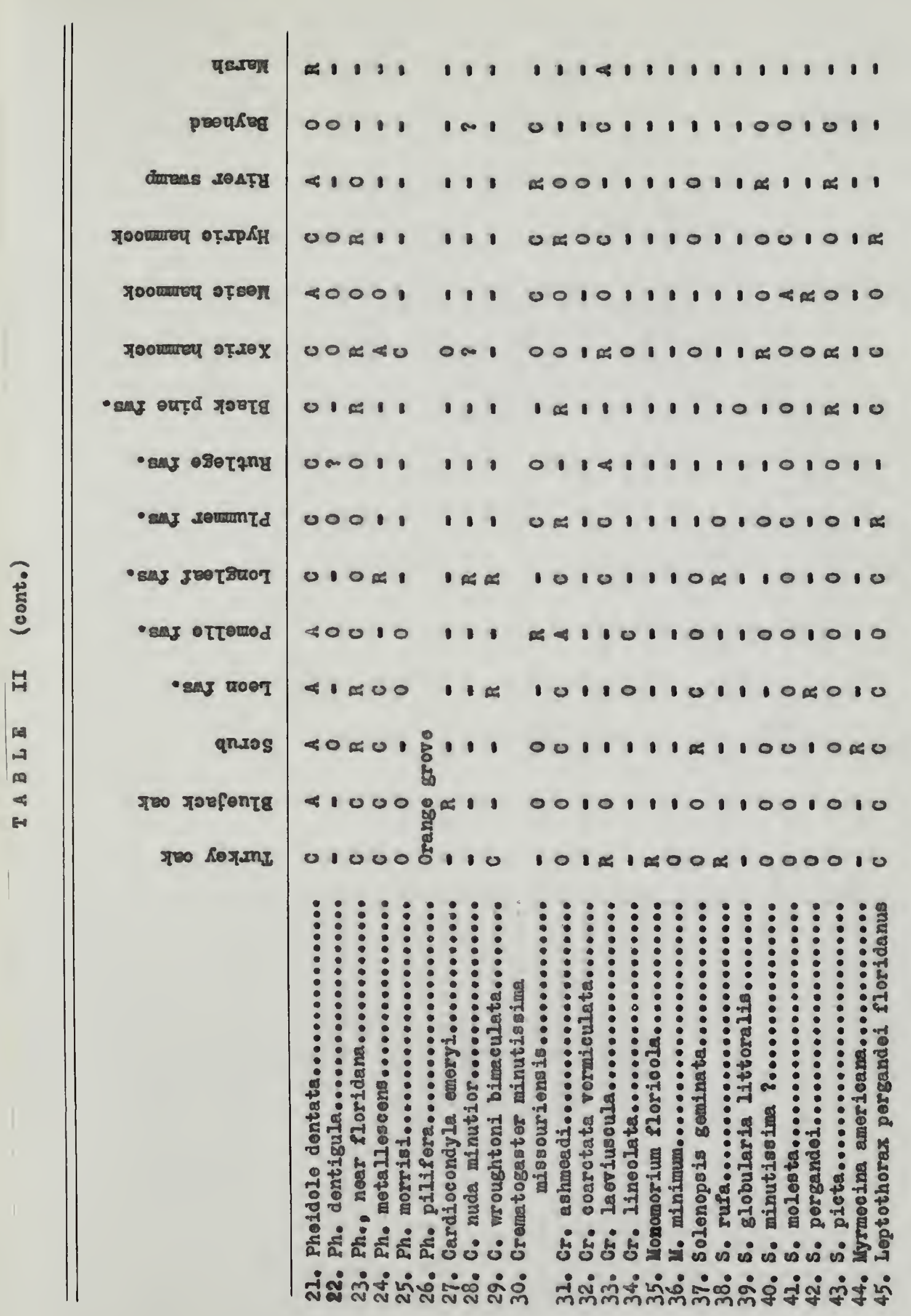




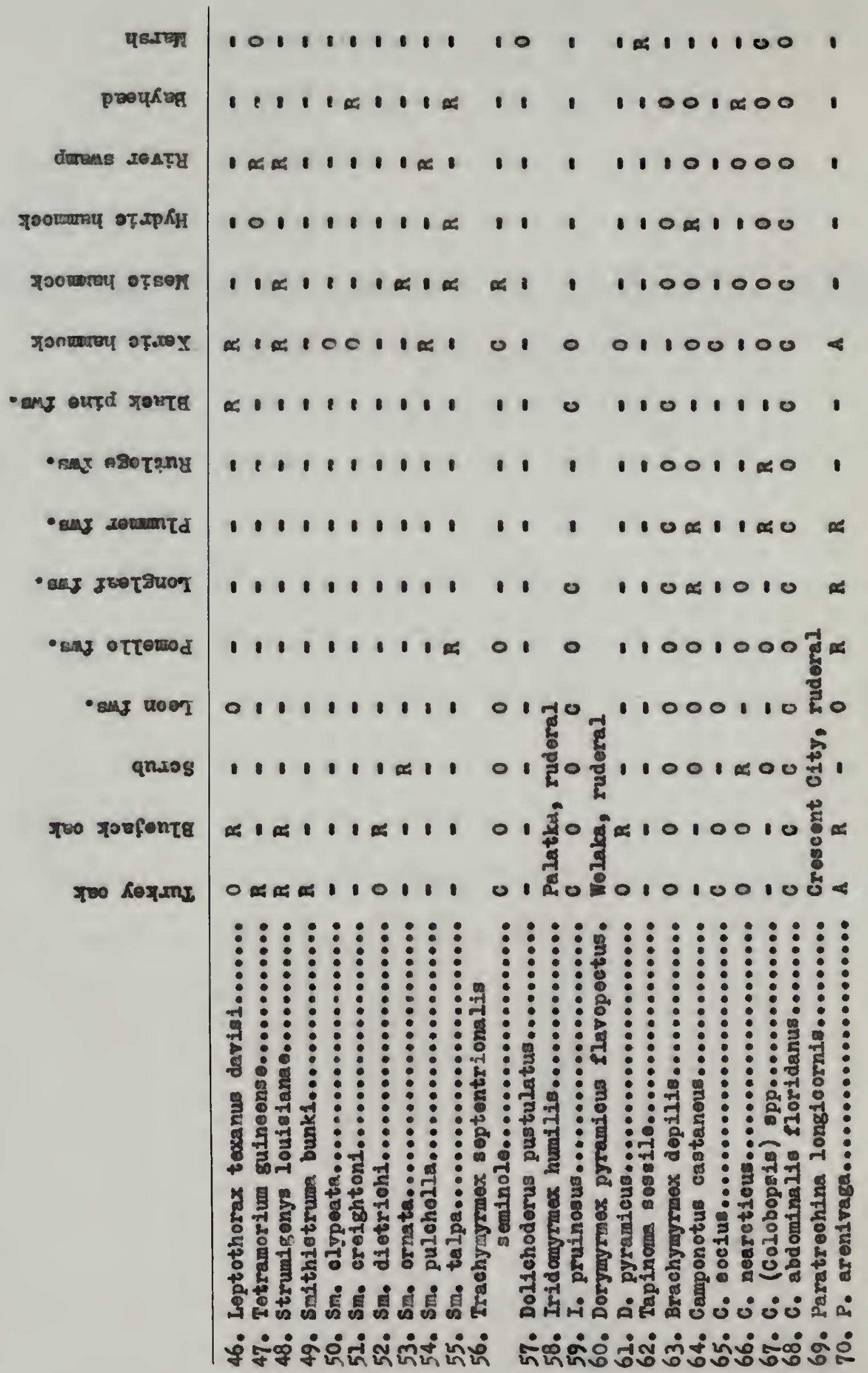




||


with 39 forms, contained the highest number of ants collected in any plant association worked.

Turkey oak and xeric hamnock offer the greatest opportunity for nesting in open sand. They are therefore ablo to attract those ants which profer or must have nesting sites in open aress. At the same time they offer dry or moist litter, a few logs, and arboreal sites.

Two factors should be mentioned in regard to longleaf pino Platwoods. First, the logging operations remove many loge which would provide nesting sites, and perhaps attract a greater number of specios to the area. Second, fire is conscientiously kept out of the Reservo. As a consequence, there is a dense growth of shrubs in the flatwoods and litter is becoming deoper over the whole arew.

Only 17 forms were taken from black pino-fotterbush flatwoods. Since the station offers very little diversity of nesting sites, it excludes most of the other ants found on the Reserve. During the sumer months it has standing water after overy heavy rain; this tends to limit the ants to those which can withstand periodic submergence.

The low number of forms in marsh can also be traced to the omall number of available nesting sites in that plant association. For all but a few months of the year there is standing water. There are no troes, but only scattered shrubs to offer small branches and twigs. The great majority of the nesting sites are between the appressed bledes of samgress.

The number of collections made (the number of nests oollected) in each station is as follows 


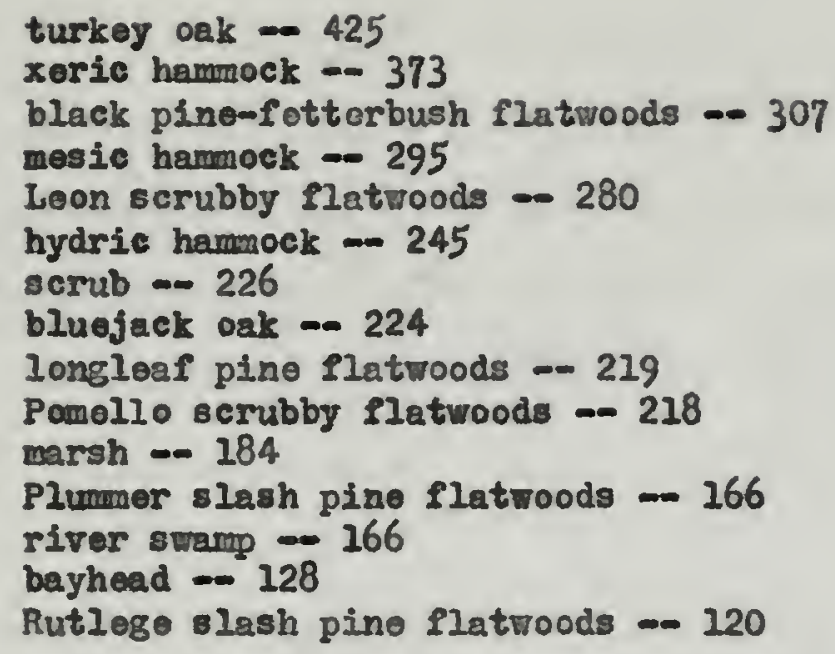

The mean number of colloctions made in one station is 238.4 , a figuro lying betwoen hydric hammock and scrub.

It will be noted that turkoy oak and xeric hamock are at tho top of the list with the greatest number of collections, as well as with the greatest number of forms. This emphasizes that these two stations are best suited to the ante for nesting situations. In this chart also, the higher and more open areas are at the top of the 11st. In this connection, the open black pine-fotterbush flatwoodo was next to lowost in the number of forms taken from it, but it is third when the number of collections is conoidered. This indicates that black pino-fetterbush Platwoods is particularly farorable for the fow ant forms occurring there. The opposite trond is shown by bluejack ork, which ie relatively low in number of collections, but high in number of ant forms; such a trend indicates that suitable nesting aites are diverse, but scarce.

In general, those places in which the molsture and litter are intermedisto are in the middle of the 11st. Last on the list are the seasonally flooded areas and the slash pine flatwoods. Marsh, which bas the fewest number of forms, is more toward the middle of the list in numbers of collections. Bayhead and the slash pine flatwoods, on the 

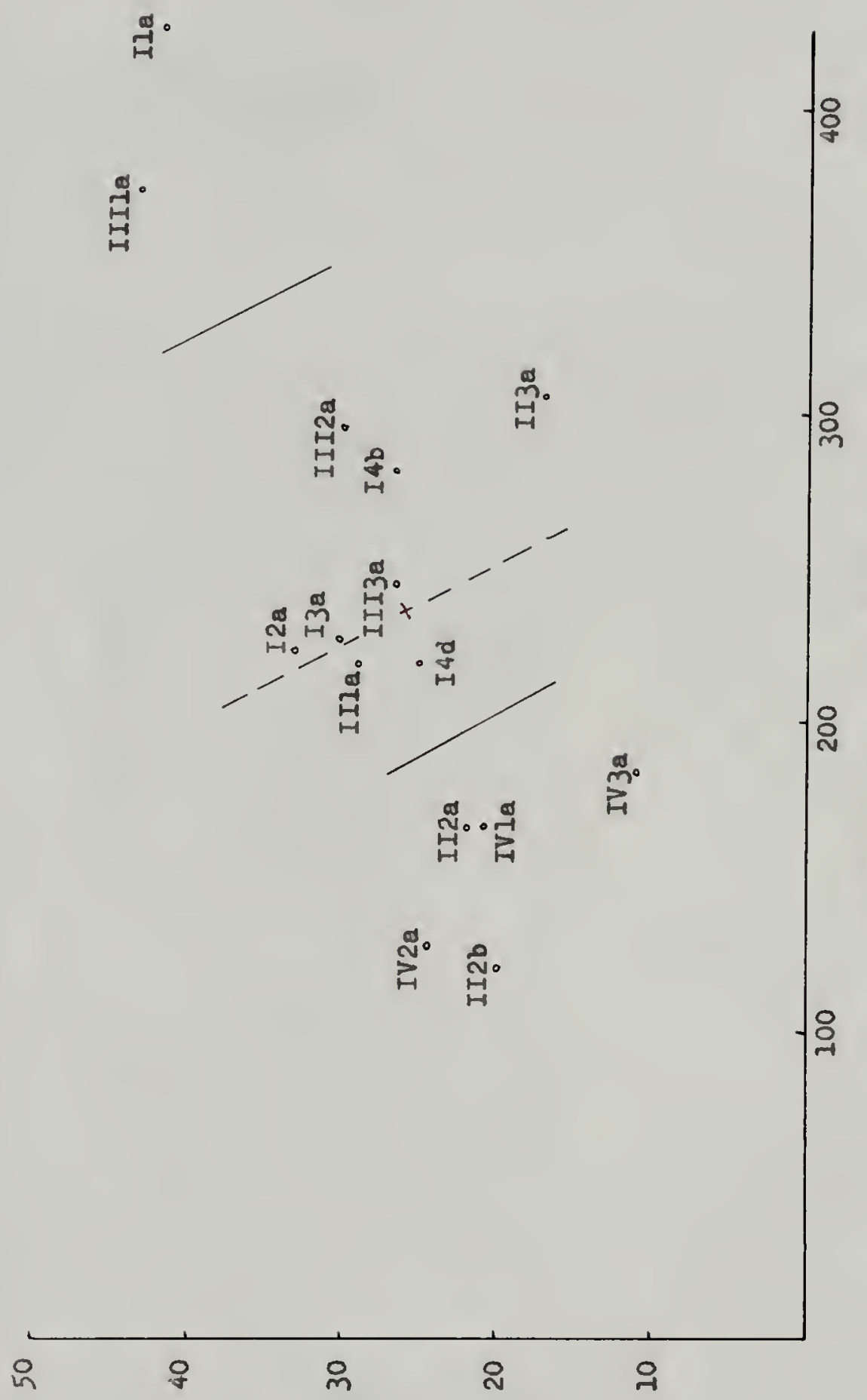

Number of Forms per Station

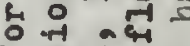
का

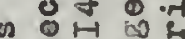
ह -न नू क्षे + 0.8

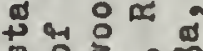
เ

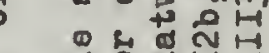

-

年悬 - 도용 $>0$ 응 †过

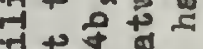
नै क्ष व कै द्य क्ष 응 क बैद 1 ช ค $-\stackrel{-1}{\sim}$ - a -1ㅐㅐ

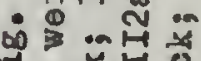
ज

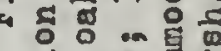
ๆ 등 응 웅도 ( ) क व

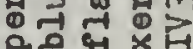


Fig. 3. -- Suitability of the stations for ants, besed on the number of ant forms per station woighted against the number of collections por station. The stations fall into three group separated by the solid black lines. In general, the higher, more open aross are highost in number of forms and number of collections por station; the lower, wetter areas have the loest of each; and the more mesic situations occur in the middle group on the graph.

The " $x$ " represents the intersection of the average number of form and the average number of collections per station. Those stations to the right of the dashed line are more ouitable than average for ants, whilo those on the left are loss suitablo. 
Since ome of the stations differ in their positions on the lists nore or less considerably, the number of forms per station and the number of collections per station are veighted in Figure 3 to obtain the over-all suitability of each station as a nesting situation. Tho numbers and letters noar each point on the graph indicate the station which that point represents. It will be noted that three major groups are shown, soparated on the graph by the solid black lineo. The group lowest in the number of species and the number of collections per etation conteins all of the ceasonaliy flooded ureas plus the slash pine Platwoods. Plumer slash pine flatwoods is higher then Rutlege slash pine flatwoods in number of species and in number of collections, bearing out its closer resemblance in the field to longleaf pine flatwoods.

The middle group contrins mesic and hydric hamock, bluejack oak, scrub, and all of the flatwoods, including scrubby flatwoode. It is possible that the thick stand of pine in the bluejack oak area is responsible for its relation to the longleas pine flatwoods on the graph. The last group, xeric hammock and turkey oak, is outstanding for the large number of species and collections made in its two stations.

The " $x$ " in Figure 3 represents tho point at which the mean number of collections per station intersects the mean number of forms per station. Those stations to the right of the dashod line are more suitable than average for ants, while those on the left are less suitable than average.

Plant succession as depicted by Laessle for the Reserve (1942:95) is shown in Figure 4. Throe psamoseres are recognizeds 1) active dunes or strongly wave-washed cands, leading eventually to scrub; 2) residual sands neither strongly wind-sorted nor wave-sorted, with rolling 


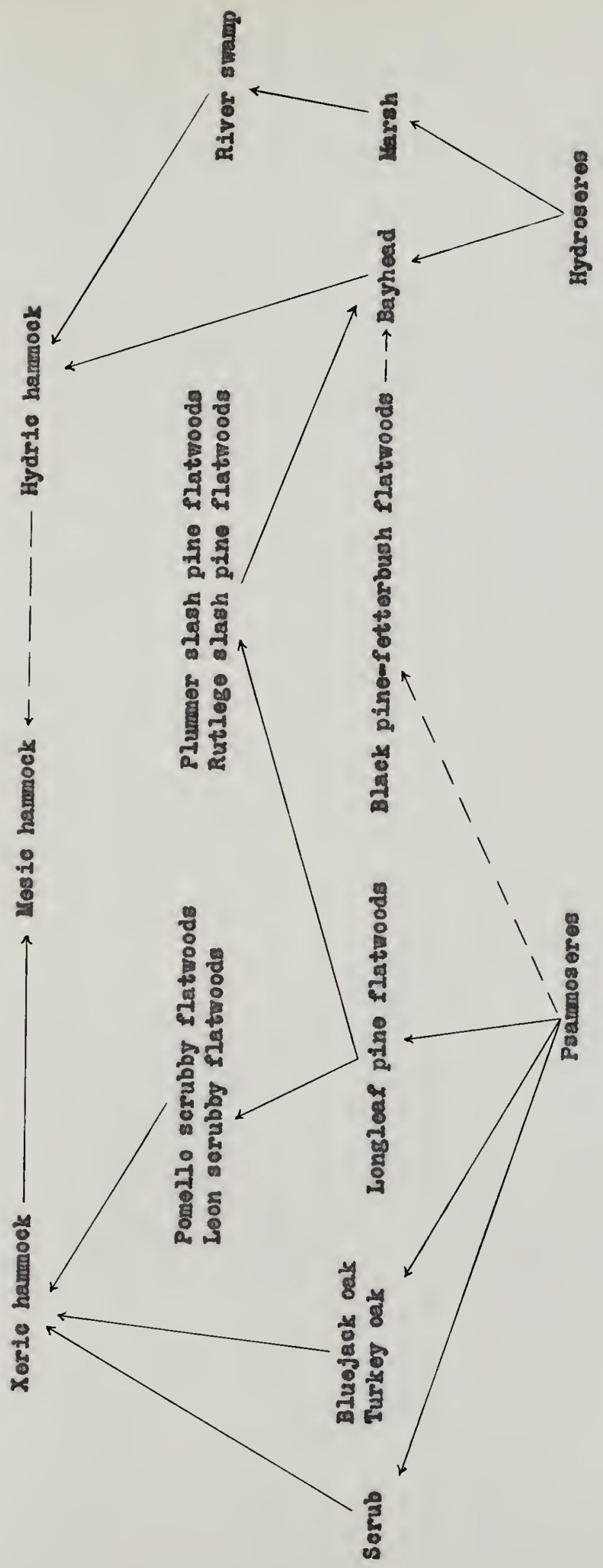

章

官

온

ร

8
-
-
8
8
8
0
0

है

8 
topography, leading to the sandhills of turkey oak and bluejack aak; and

3) washod and sorted marino sands, with flat topography, loading to longlear pine slatwoods. The hydroseres lead, on the one hand, through successive rigager to baghead, and on the athor, throwgh Bimilar etages to marsh. The relationships of the black pine-fatterbush flptroods are obscure, but it is possiblo that thoy originato in imuch tise eamo way as the longlesf pine flatwoods, and that bayhcad vagetation replaces the flatwoods from the lower portions. The trensition frow hydric hanalock to mosic hamock is a.lec fersible, but Laceglo haz rot ousGrvod such a roplacement on the Reservo. It $w 11$ be notod that longloaf pino flatwoods may be replaced by either scrubby flatwoods or slash pine flatwoods, depending upon whether succession takes place in the higher or the loner portions. Inessle reoognizes three fire oubcilimaxess 1) scrub; 2) the sandhills; and 3) longleaf pine flatwoods. The olimax is mesio hamock. In goneral, those stations near each other in sucoession are found near each other on the graph (Fig. 3). This Bituation is probably a rofleotion of the moisturo conditions in the various associations. The groups on the graph could be callad xerle, mesic, and hjdric, with littlo ororlap. The graph show that the hydric situations haro the least number of spocies and colloctions por station, whilo tho serlc situations have the most.

Another important relation is plotted in Figure 5. The solid bleck line shows the number of ant forms occupying one otation, the number occupying two stations, ote. The dashed line shows the number of forms per given number of stations for those forms collected more than once; and the line of dashes and dote, for those collected more than twioe. Note that only in the first case is there a large number of 


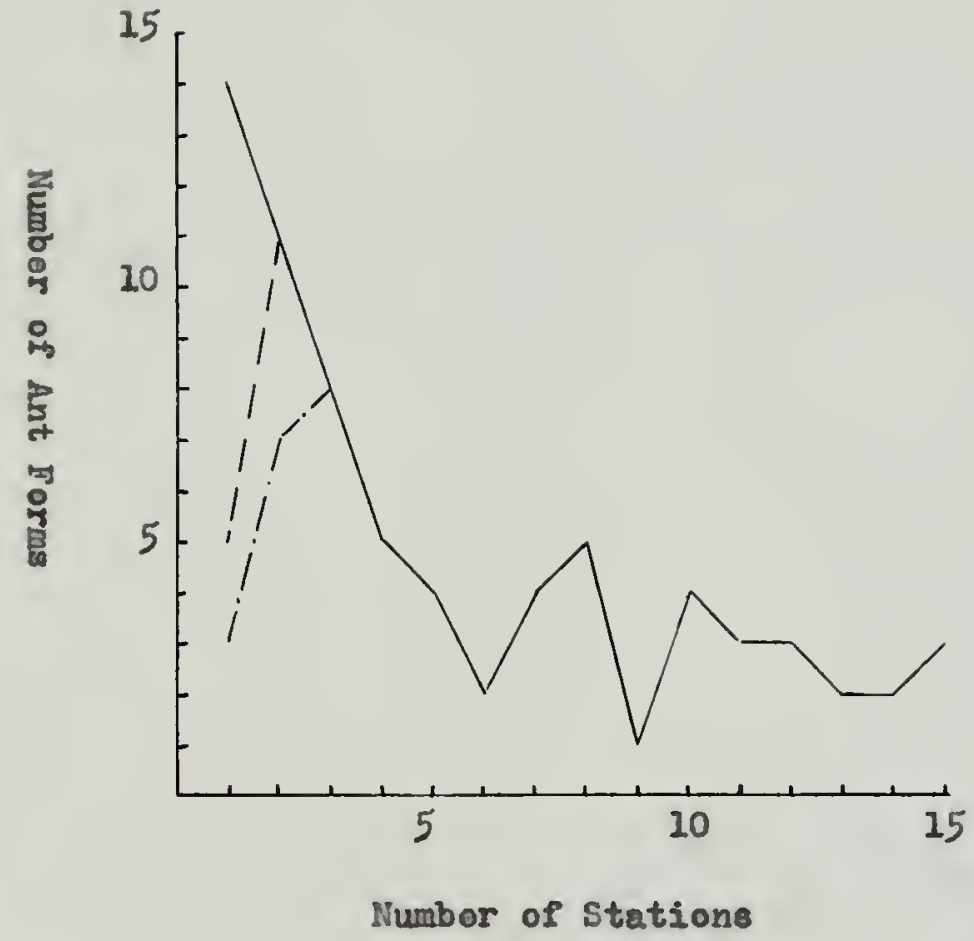

Fig. 5. - Number of ant forms confined to a given number of stations. The figure shows that 14 forme, or $19 \%$, were confined to one station when all forms collocted are considered $(\longrightarrow)(N=71)$. This number drops to 5 forms, or $8 \%$, when thoso forms collected only once aro not included $(--)(N=62)$, and to 3 form, or $5 \%$, when only those form collected more than twice are considered $(-.-)(N=56)$. The sraph tends to bocome level at 2 or 3 forms for the higher number of stations. 
form (about 19\%) taken in one station. In the case of those ants which were collected more than once, only 5 , or $8 \%$, are confined to one station. of those forms collected more than trice, only 3 ants, or about $5 \%$, are limited to ono station. As this procodure is continued, the number of ants in only oae station tends to becose smaller and will finally reach zero at oleven colloctions.

The dashod line graph has a poak there tho number of stations equals tro. In graphs excluding ant forms colloctod two tines or $20 s 8$, throe times or less, otc., the peak moves over to throo stations. The cause of this peak is obscure, but it may indicate that the ants of the Reserve vill, in most oasee, be found to occupy at least threo stations whon onough colloctions are mado.

It cen be pointed out that the graphs do not dip strongly as the number of atations is increased. They tond toward a otraight line at two to throe forus por given number of stations.

The $19 \%$ of the ant forms taken in only ono station is comparable to the 20\% of the ant forms of the Chicago region that Talbot (1934) took in one plant association. Likewise, Gregg (1944) showed about $24 \%$ of the ant forms of the same region confined to one plant association, but cole $(1940)$, in the Great Smoky Lountains, Pound about $48 \%$ of the ants confined to one plant association. His high percentage in part have been caused by the differing altitudinal levels of his plant associations. Neither Talbot nor Cole mentions the number of times oech ant form was collocted. Ivon though Gregg gives relativo abundanco figures for each apecies, those apply to the whole area worked, rather than to his plant associations. On the basis of the figures he presents, however, nono of the ants collected in only one plant association was comon or 
abundant. Whon his ants vere found to be common or abundant they were always collocted in more than one plant association. This also holds true for the Reserve. Only those collected rarely or occasionally wore confined fo one station. This fact makes it plausiblo to suggest that in their distribution, ants do not show as much dopendence upon stations based on plant associations as other animals.

It is interesting to nate that only three of the form listed by Talbot as confined to one plant association wore found in but one plant association by Grogg ten years later. In view of this fact and in consideration of the obsorvations made during the prosent study, it bocomes quite clear that oven after a thorough invostigation of a given area has been couploted, continued collecting in that area will increase the number of stations in which certain of the ants are found. This can also be used in support of the contention that ante are not as restricted by factors in plant association-goil typo combinations as aro other animals.

\section{Distribution in the Strats and Nasting Sites}

The ant forms collected on or near the Reserve were found to have the following distribution as to stratas

$$
\begin{aligned}
& \text { subterranean stratum - } 38 \\
& \text { surface stratum - } 38 \\
& \text { herbaceous stratum - } 11 \\
& \text { arboreal etratum - } 16
\end{aligned}
$$

The subterranoan and surface strate contained a jority of the ant forms on the Reserve with a total of 58 in the two. Only 19 forms nested in the herbaceous and arboreal strata.

Table III show this relationship. Of the total of 75 ants, 1 form was found only in buildings, while for 10 others no definite nesting site data wore gathered. A few collections wore made which may 
Found only in one etratua - * Preforrod stratum $-P$ Additional etrata $-x$ $y=64$

\section{S P E C I E S}

$\begin{array}{lll}\text { Subter- Surface Hor- } & \text { Arbore- } \\ \text { ranean } & & \text { becoous al }\end{array}$

1. Eeiton nigrescens...............

2. E. opacithorax.................

3. Amblyopone pallipes.............

4. Proceratium croceum.............

5. P., near slaceum..............

6. Buponera gliva................

7. Ponera ergatandria.............

8. P. opacicopo...................

9. P. trigona opacior.............

10. Odontomachus haematoda

insulario...............

11. Pseudomyrma brunnea...........

12. Ps. pallida..................

13. Pogonomyrmex badius...........

14. Aphaenogaster ashmoadi.........

15. A. Ploridana..................

16. A. fulva......................

17. A. lameliidens ..................

28. A. macrospina................

19. A. texana.....................

20. A. treata $\ldots \ldots \ldots \ldots \ldots \ldots \ldots \ldots \ldots \ldots$

21. Phoidolo dentata..............

22. $\mathrm{Ph}$. dentigula.................

23. $\mathrm{Ph}$, , near Iloridana...........

24. $\mathrm{Ph}$. netallescens..............

25. Ph. morrisi.................

26. Ph. pliffora.................

27. Cardíocondy la emoryl...........

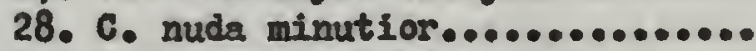

29. C. mroughtoni bimaculata......

30. Crematogaster minutissima

miss ourionsis.............

31. Cr. ashrocadi.................

32. Cr. carctata vormiculata......

33. Cr. Lavifuscula.............

34. Cr. Iineolata................

35. Uonomorium Ploricola..........

36. 4. minimum...................

37. Solonopsis geminata........... $x$

$x$

$-$

-

$-$

-

-

-

$x$

$\mathbf{P}$

-

-

*

*

*

$x$

-

*

-

*

$x$

$x$

$x$

P

*

$*$

$?$

-

-

$x$

-

-

-

$x$

-

*

p

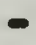

$-$

-

-

-

-

-

$x$

-

-

$x$

P

-

-

-

-

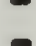

$-$

$-$

$-$

-

-

-

-

-

-

-

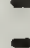

-

$x$

\section{-}

-

-

-

-

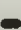

-

-

-

$-$

P

$x$

-

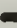

-

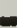

3

-

$-$

-

3

-

-

-

-

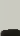

$\sigma$

$-$

-

$x$

P

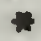

P

$x$

3

-

$-$ 
Subter anear
Surface

Herbaceous
Arborea.

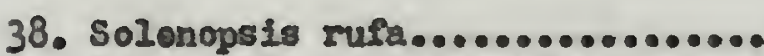
39. S. globularia littoralis........ 40. S. minutis sims 3.............. 41. S. molesta.................... 42. S. pergandei................... 43. 5. picta ..................... 44. Hyrmecina americana............. 45. Leptothorax pergandei Iloridanus 46. L. texanus davis $1 \ldots \ldots . . . . . . . .$. 47. Tetramorium guineense.......... 48. Strumigenys Iouisianae......... 49. Smithis trura bunki............. 50. Sm, cIypeata.................. 51. Sm. areightoni................ 52. Sm. dietrichi.................. 53. Sa. ornata.................. 54. Sm. pulchella................ 55. Sa. talpa..................... 56. Trachymyrmes septentrionalis

sominolo................. 57. Dolichodorus pustulatus........ 58. Iridomyrmos humilis............ 59. I. pruinosus ................. 60. Dorymyrmex pyramicus elavopectus

62. D. pyramicus.................. 62. Tapinowa sessile.............. 63. Brechywyrmex depilis............ 64. Camponotus castancus............ 65. C. Eocius.................... 66. C. nearctieus................. 67. C. (Colobopsis) spp........... 68. C. abdominalis floridanus....... 69. Paratrechina longlcornis....... 70. P. arenivaga................... 71. P. parrula $\ldots \ldots \ldots \ldots \ldots \ldots \ldots \ldots \ldots \ldots \ldots$ 72. Prenolopis imparis............ 73. Formica archboldt.............. 74. F. pallidefulva .............. 75. F. schaufussi.................

P
-
-
P
3
3
E
-
-
-
-
-
-
-

In buildings

*

$x$

- 
or may not have beon colonies; they are indicated with a question mark. The 10 ants for which no data were obtained and the ruderal form, along with the questionable collections, were not included in arriving at the distributional data on page 38. The number of ants concernod was therefore 64. A single " $x$ " indicates that the form was collected too few times for a preference to be rocognized in Table III.

Distribution according to nesting sites was as follows

Subterranean straturn

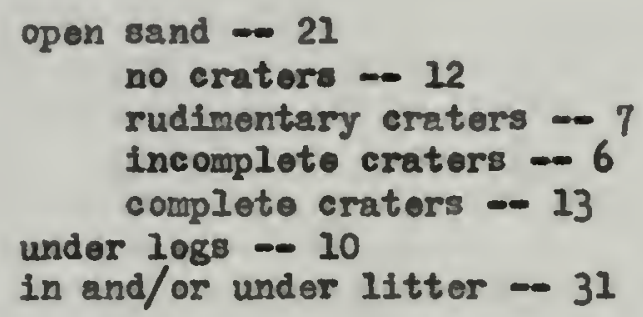

There were 34 forms which lived under cover of either logs or litter. Nests of 9 forms were found under and in loge.

\section{Surface stratum}

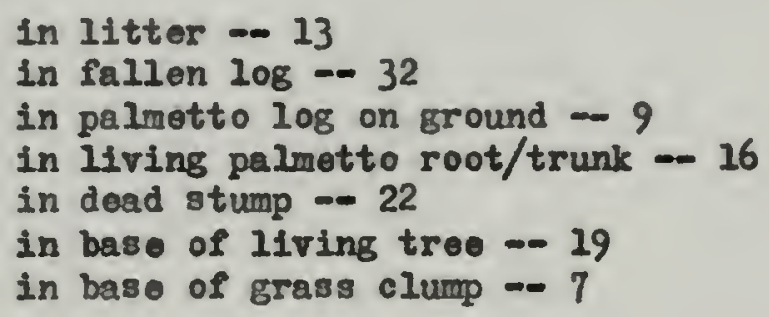

Herbaceous otratum

$$
\begin{aligned}
& \text { between sawgrase blades }-4 \\
& \text { in tall graes stems }--9
\end{aligned}
$$

Arboreal stratum

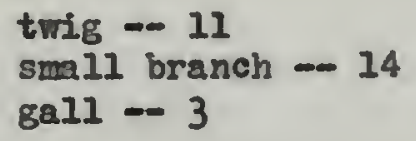


Only 11 ant forms were found in over 6 of the possible 16 nesting sites. The highest number of nesting sites (14) was occupiod by Camponotus abdominalis Iloridanus. Naxt highest was 12 nosting sites occupiod by Phoidole dentate and Paratrochina parvula. It will be noted that these three ants are the same that occupy all of the stations. With the escoption of Pheidole dentata, which occupies only 3 strata, they oocupy all 4 strata also. Loptothorax pergandel floridanus, which occupies 11 nesting sites, is the other ant found in all strata. The distribution of these ants in stations, strata, and nesting sites points to a direct correlation botween the number of stations occupied and the number of streta and nesting sites occupied.

Figure 6 shows the relation between the number of stations occupied and the number of nesting sites occupied for each ant collected more than three times. It is a soatter diagram in which the number of stations any given ant form oocupies is plotted against the number of nesting sites that form oocupies. An examination of this figure shows that a large number of forms are limited to from 2 to 5 stations and from 1 to 3 nesting sites. The diagram shows that the number of stations occupied by any form increases faster than the number of nesting sites occupied, indicating that the ants are more likely to be confined by nesting sites than by stations. However, the diagram goos to substantiate the premise of the preceding paragraph, in that as more stations are occupied, more nesting sites are also occupted. 


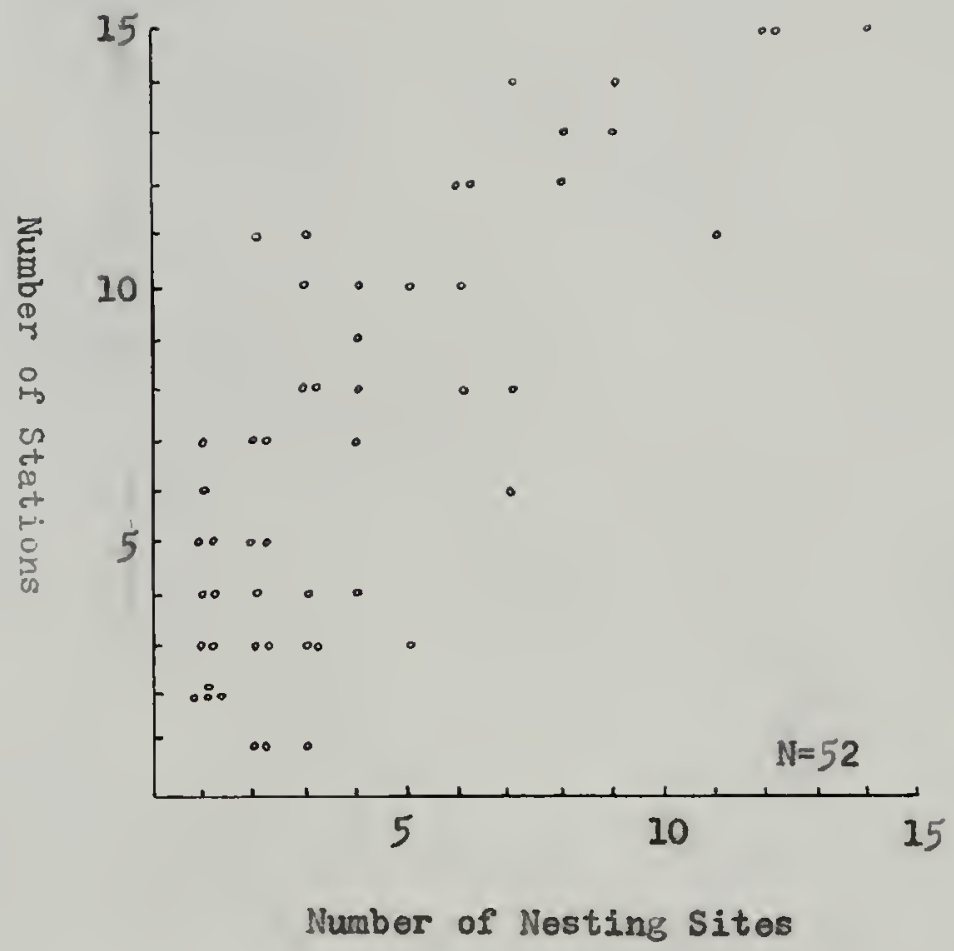

Fig. 6. -- Scatter diagram to show the relationship betwoen the number of stations occupied and the number of nesting sites occupied for each ant form collected nore than three times. The number of forms involved is 52 . 


\section{Activity Rolationships}

The speed of novement of each ant form varies to sorne extent With changes of temporature and relative humidity. During the course of tho present study, this "amount of activity" wes estinated aubjectively for individusls. The speod was then corrolated with temporature and relative huridity readings taken at the ground surface.

The date on this subject collectad during the field sork proved to bo complox whon all of the ant forms wore studied together, and in many cases when merely one form was considered. Some ants chose one axtrame in physical factors in which to forage, whereas other forms chose the opposite axtrene. In general, the diurnal foragers displayed a moderate amount of activity in their above-ground activities when the temperature was above $20^{\circ} \mathrm{C}$. If, on the provious night, reletive humidity was high and the tamparature low (below $10^{\circ} \mathrm{C}$ ), the ants vrere slower to resume activity the subsequent day. At the other oxtreme, activity has been observod from nests of Camponotus abdominalis floridanus at $53^{\circ} \mathrm{C}$. , and most of the ants havo boen seen foraging at temperatures abovo $30^{\circ}-35^{\circ} \mathrm{C}$.

Seasonal variation in the foraging habits of soveral forms has also boon observod. Bany ant forms romain in their nests during periods of cold. On the other hand, during the vinter months many forms will remain idlo for a short poriod even though the tamperature romins mild, and no frost appears at night. A notablo exception is Phoidolo dontata, which can be seen foraging oven on chilly days. 


\section{AMNOTATED LIST}

In the following annotated list, the discussion of erery ant form has been arranged so that topica appear in the same order. Any points of texonomy which are felt to be important are discugsed first. The distribution through plant associations, atrata, and nesting sites, are listed next. Comparisons are made with the ant's distribution in Gainesville or other regions, or vith another ant on the Reserve which may replace it in some of the plant associations, if such a discussion is felt necessary for a botter undorstending of the habits of the ant. Notes as to its Iife history are followed by others on its activity. Miscellaneous remarks are added in a final paragraph.

As indicated in the introduction, the texonony of the ants in the present study is based on Creighton's recent work (1950) in which he reduced the quadrinomial system, prevalent until 1950 in the family Formicidae, to the trinomial system used in the dynamio viev of nomenclature. Any departure from the names which Creighton uses is explained in the text of the Annotated list under the ant concorned. Some forms were found during the study which could not be definitely identirled. Such forms that were reoognizebly different are listed, and comments are mado concerning thoir taxonomic status.

In presenting the Iife history data, an attenpt was made to dotermine an average number of workers present in a flourishing colony of each ant form. In oome cases this has boen impossible, or has been derivod from the counting of only ono nest. In addition, the scasonal appearance of imatures, walos and famales is indicated for each forw. Moeourements have all boen rade from the latoral viow. Total length is the sum of the distances from the base of the mandibles to the 
beck of the head, from the most anterior part of the pronotum to the base of the propodeum through the abdominal pedicols, and from the anterior to the posterior of the abdomen. All measurements were the shortest straight linos covering tho given distances.

Fourteen ant forms were taken during the present study which had not been recordod from Florida. Thoy ere as follows

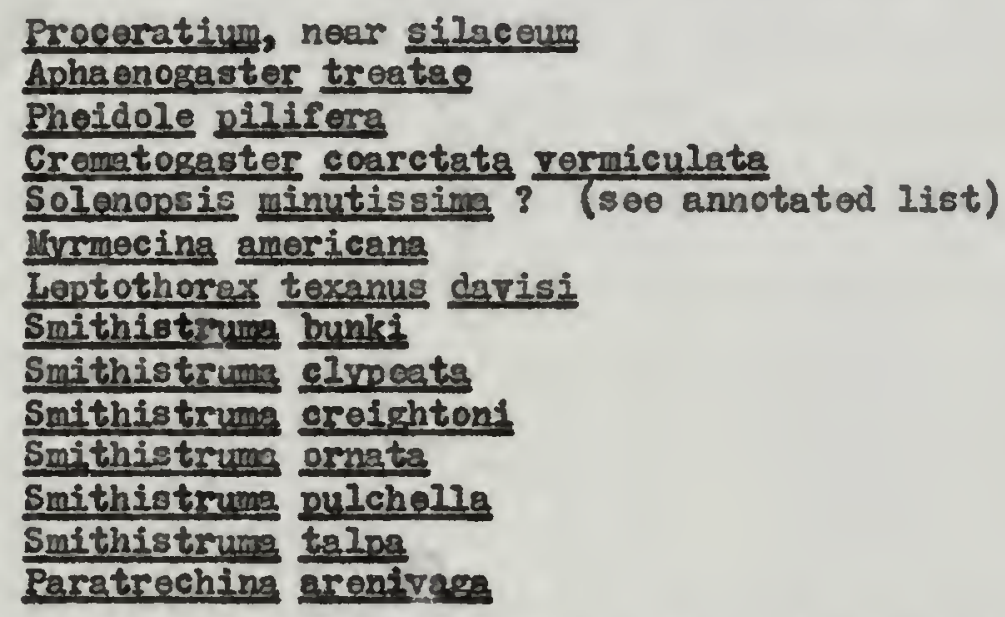

Several ant forms taken in the Gainesvillo Region vere not

found during the present study on the Reserve. These are as follows:

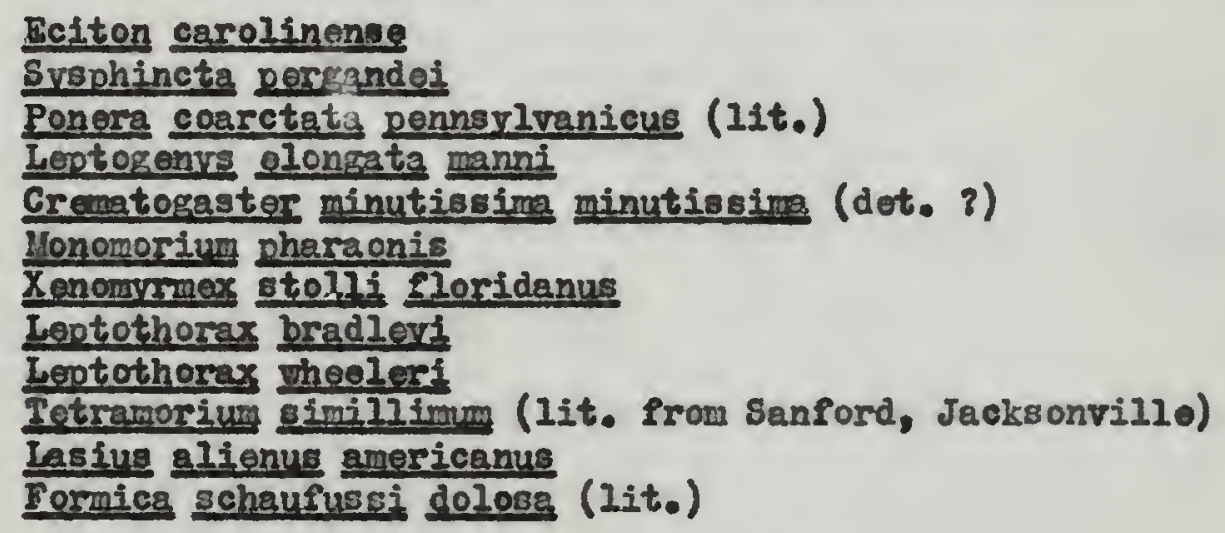

Other ants taken in Welake, but not in Cainesville ares

Amblyopone pellipes

Proceratium, near silecoum

Proceratium croceum

Ponera ergatandria

Aphrenoggster macrospin

Aphrenogester trentae 
Pheidole dentigula

Phoidolo pillfera

Cardiocondyla wroughtoni bimaculata

Solonopsis minutissima?

ifrrmocina ameriogna

Leptothorex texanus devisi

Smithistruma bunki

Smithistrum Elvpeate.

Smithistrume diotriohi

Smithistrume ornata

Smithistrume pulcholla

Smithistrumg talpa

Formica archboldi

The following ante, taken within serenty miles of the Reserve, have

boen cited in the literatures

Phoidole megacephala (St. Aug.) (not listed by Creighton, 1950)

Pheidole anastasii (Sanford)

Leptothorax curvispinosus (Jacksonville; pinned specimen)

Tetramorium simillimum (Sanford; Jacksonvillo) 


\section{FAUILI FORMIC IDAT}

\section{Subfamily Dorylinae}

\section{Eciton nigrescens (Cresson)}

On July 5, 1948, the single collection of nisrescens on the Reserve wao recorded for mesic harmook. The nest was under litter which had gathered in the conter of the base of a stump rotted so that only the rim was left standing. The nest extended into the stump, but the major portion was in and under the moist litter in the sturp and in the nearby chambered sand.

All of the workers were huddled in a tight bell. No activity wes observed until the workers woro disturbed, but then the workers ran hurriedly in all directions. No individusls of tho reproductivo casto were seen, even though the nest was dug into, and returned to later. Cole (2940:38) made some observations concerning the nesting habit of this ant in the Great Smoky Mountains. Tro colonies he found there "wore beneath large, flat stones, loosely applied to the soil, in open grasey areas.... Deop vithin tho soil the ants occupled large broodfilled chambers constructed around imbedded and partially doceyed treo roots.....The soil, eron at ohamber lorel, was dry and firm."

\section{Eaiton opacithorax Enery}

E. opacithorax was found occasionally in longleaf pine flatwoods. All nests were under the bark and loose wood of stumps or $10 \mathrm{~g} s$, and extended into nearby litter. All loge fros which this ant was taken wero longleaf pine (Pinus palustris). In tump the ant occupied all availablo speco under tho bark and all suitable crevices; in logs tho ant nested in a 
length of soveral foet of wood.

One nast in a sturap was estimated to contain between 40,000 and 50,000 workers. These numbers were obtained by placing all of the ants in vials, counting the number in one vial, and mosuring this vial against all the others.

Numerous indiriduals of Eciton were taken at the openings of a nest of Solenopsis gemingte in the sand one and ono-half feot from a - tump in which the colony of oprelthorax was locatod. The Eciton nest abutted a nest of Brachyarsmex denilis, and partially occupied a nest of Crematogaster 18eviuscula in the stump. Groups of Eciton wore also taken from termito gallerioo in the stump. Leptothorax porgandei Ploridanus and Aphaonogaster macrosping wore found wandoring near the stump. The following animale vere taken through the Berlese funnel from the litter of the Eaiton nests

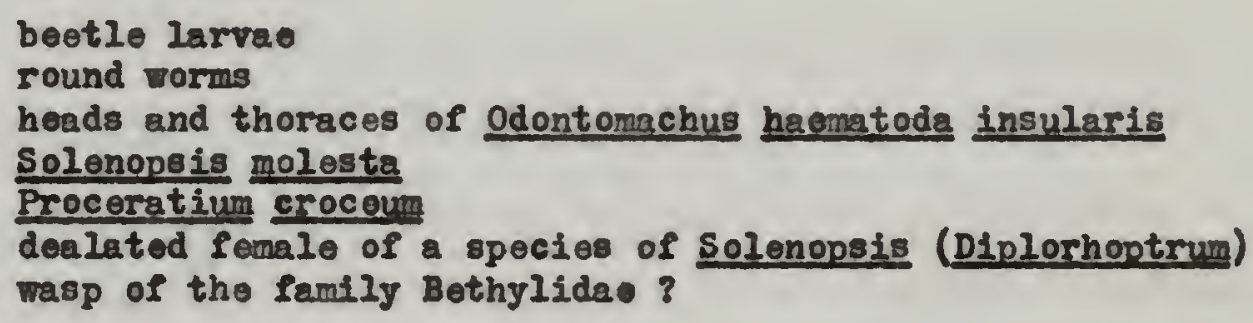

From another nest the following were takens

\section{Brachyrarrmex depilis}

Paratreching parvula diplogods

A large portion of a colony with its nest litter was placed in a large lard can and brought into the laboratory. To prevent tho escape of the individuals, the lard can was placed on a platform surrounded by water. Vary few workers, however, were observed wandering on the platform, although workers carefully placed the dead or injured individuals in a pile outside of the lard can on the platform. 


\section{Subfarily Ponerinao}

\section{Amblyopone pellipes (Haldeman)}

Previous to Bromn's paper (1949), pellipes was considered a species of Stigmatome. Brown, however, has given reason to place Stignatomes as a subgenus of Amblyopone. It is treated as such in this peper.

One collection of Amblyopone was made during April in bayheed. Several ants vere gathered in moist litter near and in forn roots. A caroful examination of the roots and litter nearby revealed no additional spocimens.

Cole $(1940 ; 36)$ has the following to say concerning this species in the Greet Snoky Mountains "The nest consists of one or two openings beneath or beside a stone or under the topmost forest litter. Almost perpendicular gelleries connoct with sall eubterrenean chambers never far boneath the surface.... These ants are nowhere abundant in the Park but seem to occupy rather circumscribed areas where environmental conditions, particulariy meisture and deep shade, are favorable. Colonieo wore most numerous in second-growth pine woods."

The collection on the Reserve, made on April 22, 1949, yielded one melo. The workers aro vory reclusive, and quickly find crevices in which to hide. Thoir color blonds with that of the 8011 and duff. Haskins (1928) has roported on tho bohavior and habits of this ant. 


\section{Procaratiun crocerm (Roger)}

P. croceum was collocted occasionally in Iongloap pine Ilatwoodo, and rarely in bluejack aak. All of ite nosts vere taken in the surface stratum fram Pallon longleaf pine logs. These logs were olther moist or wot, with the wood pulpy or eoft and separable between the asunul ringe. The nesto extendod toward the conter of the log.

Two colonies wero counted. Ono contained 24 vorkers, 12 uallows, and 1 male. The other, cooningly complote, had only 3 workers. There was a quoen in each of these nests and no irmatures vere noted. The male was taken on Novembor 23, 1949. It was found about two foet from the nest, and since no other maloe wore taken, it is possible that a flight had rocently taken place. Workers of crocoum were slugsish in thoir moroments, whilo the lo alert and mored quickly.

Colo $(1940,36)$ Indicates that his single colloction of this species in tho Great Smoky Mountains was mado in a vot, dense area of mixed cove hardroods. Ho add that the $10 \mathrm{~g}$ in which the ant were found wa casly broken apart into I1rm, wet pieces. Tho nost was "woll toward the center of the $20 \mathrm{~g}$, in the more $11 \mathrm{~mm}$ coro wood" and had "small galleries and chambers chiefly with longitudinal ponotration. In all tho nest corored a longth of [only] about 4 inchos.... The colony was rather small, boing composed of about 30 workers." In the Chicago aroa, Gregg $(19441460)$ records the presence of this spocies beneath dung.

\section{Proceratium, near giliceum Roger}

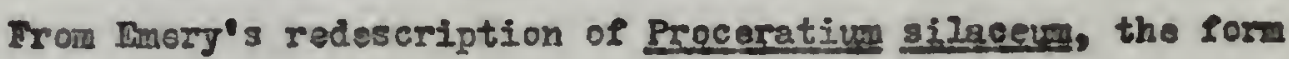
deelt with here socces to be close to this latter opecies. Horever, X. R. Smith, to wham epecimens were seat, would not place the form 
boyond genus. In an attampt to revise tho gonus ho found (in litt.) that "Ihe previously mentioned characters for separating the two species did not appear depondablo and I could not discover any ner characters that wero any good oither." Thus the form is givon an uncertain taxonomic status.

One collection of this form was made on October 17, 1948, from the base of a slash pino. Tho colony was nesting in bark buried undor the soil surface. Six individuals wero takon. As in P. crocoum, tho workers are sluggish in their movenents.

\section{Euponera Bilve (Rogor)}

Euponere gilva was confinod in its distribution to the moist or wot hanmock areas. It takon once in mesic harmock, and occalionally In hydric hameck.

Its nesting aites wore in fallen loge. A typical nest extended for two and one-half inches in debris under the bark of a log. Specimons have also boen taken from littor, and from the dobris decomponing botwoon the rootlotg in and undor the litter.

A nest from hydric hamook conteined 26 vorker and one queen. The egge, larrao (which are woll equipped with body spikes), and pupae were observed in separate places in the nests, with the pupae usually more toward the ourface, or toward the outside in 208 neste. Since so fow nests wore seen, no further life history data were obtained. Although tho ents aro alor in thoir morements most of tho time, thoy are quick to find conceriment. Thoir olusiveness is inoreased by their color which is oimilar to that of the wood whore they Live, and by thoir ability to hido motionleos in orery narror orovico. 
Smith (1934:562) rocords E. Eilva from Hississippi, Alabam, and Tennesseo. His observations on the nesting sitos coincide with the above. Ho states that its neste "In sone instances contain as wan ao from one to several hundrod workers and often as many as ton or more dealated queens". He romarks furthor that Creighton has found fully developed males and a winged female on June 20 in southern Alabama.

\section{Ponore ergatandria Forel}

Lention noeds to be made of a number of small specimens of P. ergatandris collected on the Reserve. These workers are in all measurements more dirinutivo than specinen taken in Dado County, Fiorida, and are likerise smallor than othor ergatandria taken on the Reservo. Wile the litter specimons fit tho description of P. erratandris which Smith gives (1936:425), the smaller Forkers from the Reserve differ in totel body length. Smith lists tho body length as 2.3-2.9 mas the smaller workors on tho Reserve measure only 2.0-2.I Mm. Moreover, tho ventral portion of the potiolar tooth is smooth in the largor specimen, and sorrate in the smaller Epecimens. Smith (in litt.) says that ho has notcd much veriation in the workers of orgetandrig, and considers all of the spocimens from the Reserva as of that specios. The saller specimens have boen found only in mosic and hydric hamocks, whereas the larger specimens wore spread winly over drier areas. Both variants will be treated together in the following discussion.

R. ergatandria colonies were taken occasionally in hydric hammock and mesic hamock; and rarely in turkey oak, bluejack aak, and black pinofettorbush flatroods. A typical nest was taken from under tho moss near the bace of a living oak troo in hydric hamock. No life history data vero obtained. 


\section{Ponera goacicons unyr}

A discussion concorring the variation in tho shape of the potiolar scale in ponera trisone opacior and in this form can be found under I. trigona opecior. Lany of the nests of onacicons, especially in marah, contained one to seroral individurls which are evidently aberrant workors. These insects have large, compound eyes, comparable to those of the quean, and the potiolo is more alender then that of the rormal vorkor. It is porhaps significant that queons were not found in nests which contained these aherrant foras.

This specios prefers the vot or flooded arees of the Reserve. It hes beon taken abundantly in marsh; comononly in hydric hamock and river swamp; and rarely in Rutlege slosh pine flatwoods, bayhead, and zoric hemock. If tho charactors now used to separate $\mathrm{P}$. ongoiceps Iram P. trisone opacior prove to bo mislesding, as some workers believe, tho spocimons taken in reric hamock and assigned to P. gpaciceps may bo extreme variations of P. trigonn opacior, a form which profers high, dry areas. P. oprcicens occurs almost exclusively in the vetter portions of tho Reserve, and tands to replace P. trigong opscior there. In the Gairesville region, B. opaciceps was taken in longleaf pine flatroods where there are more fallen logs than in the asme plant association on the Reserve. Because of its preference for wet areas, it ought to occur also in at least the lower portions of mesic hanmock.

Lost often this ant nests in the bases of sawgrass plants between the appressed leaves. Niany times the ant can be found in the wet or saturated moss-covered stumps of the plants where thore is un intorraingling of roots in the decomposing, appressed leaves and wet dobris. The other nesting sites, in order of preforence, ares 
1. fallan Iogs

2. dead stumps

3. bases of living trees (under moss and litter at water ourface)

4. In Iitter (vet)

5. palmetto roote on ground

6. under mat of palmetto roots

7. under mat of palmetto trunks

In general, the nests are wot to saturated and built in dobris. Most of the nests, especially those in sawgrass, are at the water surface, or just above or below it. (In this lattor case, the tight growth of the plant parts soems to keep the water from the nest.) In situations which are less wot, the insect continues to simulate the abovementioned nesting conditions in its choice of wet, pulpy wood of logs, or the debris found under the bark of logs or atumps.

0 f 5 nests counted, the number of workers varied from 15 to 84 , with an average of 40 per nest. Fech of theso nests containod from one to three of the aberrant workers described above, and none contained a queon. Immature forms probably occur in all months, but from September through November very few were noticed in the neste. Fecales are produced from September to Norenber, and males from Oetober to November.

This is a last moving and ovasive ant which blends with the color of its surroundings. It is much less active in winter months, although this is the period winged forms are in the nest.

\section{Ponere trigong opseior Forel}

From an examination of the spocimens of this form and of $\mathcal{P}$. opacicens in the llus eum of Comparative Z00logy, there appears to be a Ereat deal of overlapping variation in the two forms. It seems clear that, in the museum colloction, the character of the shape of the 
petiolar scale, which is used by Smith (1936) to separate the two forms, is not distinctive. Hany of the specimens labelled as one form are more like the description of the other form. The specimens of opecicope and of trigona opacior collocted from the Reservo, however, fall into two distinct classes on the basis of the petiolar scale. Perhaps the shape of the petiolar scale will be shown to be dependent on the environment of the nest, and therefore of no use as a key character. On the other hand, it is possible that the specimens in the $M_{\text {. }} C$. Z. have been misidontified.

In 2.11 rospects oxcopt total length, the Wolaka spocimens agroo with Smith's description (1936) in which he cites the length of workers of opgcior as 2-2.3 man. Workers from the Reserve meaure 2.4-2.7 $\mathrm{mom}$. in total length.

P. trigona opacior tends to prefer the higher, drier plant associations. It tas tak commonly in xeric hammock; occasionelly to comonly in turkey oak; occarionally in bayhead and Plumer slash pino Platwoods, in all woll-drainod areas except Pomello scrubby flatwoods, and in the hamocks; and rarely in the other flatwoods stations. No oollectione have been made from Porallo scrubby flatwoods or the seasonally flooded areas of the river swamp and marsh. Colo (1940:37) points out that in the Great Smoky Mountains the ant does not nest in dense wet roods, but profers rather open areas where the soil is able to contain an appreciable amount of moisture.

A majority of the nests of this ant occupied the surface stratum. The serveral nosts rocorded from sand, moreover, did not artend moro than a for inches into the sand, but wore mostly under litter. The nests in the surface stratum were usually ascociated with debris, although some nests 
wero found with littlo or no dobris. Several of the nests taken in faIlon logs were found under the bark against fairly hard wood. The order of proference of nests in the surface stratum is as follows:

$$
\begin{aligned}
& \text { 1. fallen logs } \\
& \text { 2. dead stumps } \\
& \text { 3. bases of living trees } \\
& \text { 4. litter } \\
& \text { 5. palmetto roots on ground } \\
& \text { 6. under mat of pelmetto roots } \\
& \text { 7. under mat of palmetto trunks }
\end{aligned}
$$

of four nests taken from wood, the number of workers varied from $?$ to 21, with an average of 13. Nono of these nests contained queens. Immature form have been found in all months. Males have beon observed in flight in Docembor and Fobruary. No information has boen obtainod concerning females.

P. trifona opaolor is relatively fast moving, and characteristically ovasive. Indjviduals are difficult to 300 because they are vory nearly the color of the wood or litter surroundins thoir neste. They Lmediately seek the first available erevice in which to hide.

llests are occaricnally found in the same $20 \mathrm{ge}$ and stumps as nests of Odontomachus hoomstods insulnris.

\section{Odontomachus haematod insularis Guerin}

O. hacmatodo insularis is a videspread ant on the Reservo, and Is vell ropresented in nearly all of the stations except warkh, where it has not beon found. It occurs abundantly in black pino-fetterbush flatroods and mesic homock; comonly to abundantly in turkey oak and hydric hamock; comonly in Leon corubby flatwoods, longleaf pine flatwoods, Plumer slash pine Platwoods, xoris hamock, rivor swamp and bayheed; and occerionally in bluojack oak, scrub, Pomello scrubby flatwoods, and Rutlege 3lash pino 
A majority of its nests have boen found in sand, almost alvays under litter or logs. The remainder of the nests wero taken in the surface stratum. Whero there are suitable logs or stumps present, this ant shows no preference between wood and sand. However, on tho Reserve, because of the existence of relatively fer suitable loge or stumpe, the most favored nesting sito was in sand under litter. In the Gainesville region most of the nests of 0 . haenatoda insularis were taken in logs.

In order of preferenco to the ant the nesting sites in which

\section{O. hacretode insularis was found in Wolake aros}

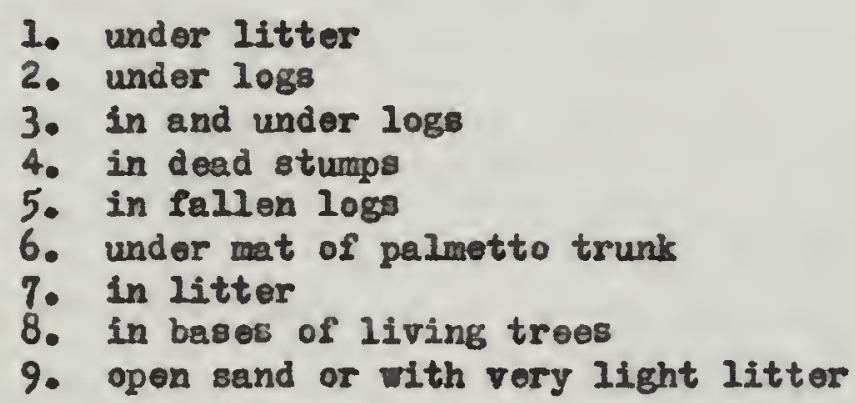

Lost nests in logs and stumps were in wood of an advanced stage of decey, although nests wore found in wood in all stages. There was no preferenco between pine and broadleaved wood, but all nests vere vet or moist. Charred wood was not rejected. Many of the nests in logs and stumps, and under logs, ramified into chambers in the nearby sand. In the bleck pinofetterbush association, several nests were found among the roots of fetterbush.

On sereral ocessions 0 . hematoda insulario has been found in the same stump or $\log$ with Camponotus abdominel1s floridanus, but the association probably depends on a common suitable nesting site. Both of these ants sometimes extend their nests into sand near the wood which conteins the major portion of their colonies. Both, moreover, 11ve under loge, but 0 . hacmatoda insularis sometines lives in aand alone. The 
chambers of these large ants are never very deop, and usually appoar to bo readymado cavitios into which the ents moved. Thoy have not spocialized in exceveting to the degree that the true orater forms havo. Hany of tho passageways, too, oem to have been constructed by oome other agent than the workern, since they are in wost cases much too large for the 1210 of the ant. The portions of the nests in sand, moreover, are comonly supported by humus and leal litter.

Large nests of $\underline{0}$. hremetoda insularis have not boen seen on the Reservo. One nost, perhaps slightly smaller than averago, contained 20 wcrkers and 3 callow workers. Inmatures have boen observed in the nests in all months, but not during cold periods. On numeroun occesions mes heve boen taken in Slight and in the nests from May through early August, but no information has boen gathored concorning tho forales.

When the soil is seturated during the sumer rainy eeson, the workers often bring thejr inmatures to the ourface and place thew under leaves. Single workers also can be seen resting under the cover of a leaf during these periods, as well as during the colder months of the yoar.

This ant 1s one of the most conspicuous in a majority of the plant associations on the Reserve. It is quite active above ground, epecially during the warmer months, and large workers, loraging alone, are somonly seen. In the cold periods, howerer, activity, both ahove ground and in the nest, is reduced to minimum, and its abseree abore ground is quite noticoable.

0. haematoda insularis is known to foed on insects. Whon large insects are caught, seroral workers cooperate in carrying the intact bodies to the nest oponing. Workers have beon attracted to the peanut butter and oatmeal beit used in mamal traps. 
Insocts which have boen found living near 0 . haematoda insularis in the same log or stump are:

\section{Camponotus abdominalis floridanus}

\section{Paratrochina parvula Reticulitermos (flavipos?) (Isoptera)}

In several instances mites have boen found clinging to workers. They have been found on all parts of the body, but especially on the hoad, gaster, and propodoum.

Foraging workers have been found in association with several other spocies of ants. Neither the Odontomachus nor the other ants were mach disturbed. In one instance an Odontomechus worker wes very inquisitive concerning tho activities going on within the crater of a nost of Trachymyrmex septentrionalis seminole. The worker repeatedly ran to the nest opening with waving antennae, but neither the visitor nor the Trachymyemex gave much attention to the other.

\section{Subfamily Psoudomyrmina}

\section{Pseudomiras brunnea $F$. Smith}

P. brunneg nests were taken occasionally in turkoy oak, Loon scrubby flatwoods, Pomello scrubby fletwoods, mesic hamnock, hydric hamock, river swamp, and marsh; and rarely in scrub, Rutlege slash pine Platwoods, xeric hammock, and beyhead. The ant shows a preference for river swamp, hydric hamock, and the dense Pomello scrubby flatwoods. On the other hand, it has been collected only once in any type flatroods other then the scrubby flatwoods. P. brunnea thus roplaces P. pallida in the wot or sersonally flooded area, whereas P. pellida roplaces 
brunnea in the rlatroods aroas. The difforonco can be attributod to the fact that pallida is able to live in tall graso stems, whereas brunnea is not. Moreover, brumno prefors the wore donse, wot woods, and pallide the wore open areas.

Almost all of the colonies of brunnes have been collected in the arboreal stratur. Nosts have boen equally divided botween true twigs and small branches. A single collection from the herbaceous stratum wes made six feot above the ground in a flower stalk of a samgrass plant.

Two largo nests of this species wero taken, one with 79 workers and 1 queen, the other with 79 rorkers and 8 queens. Other nests contained 18 workors and 1 queen; 9 workers and no queen and 7 vorkers and no queen. A mating Plight occurred on June 17, 1950, and winged forms were observed in provious yoars from June through Soptember. Imature. Porme occur in the nosts almost all year, and usually thore are a large number of larrae, j.0., 30 to 65 large larvae and many more small ones.

P. brunneg is agile and is able to disappear easily on the other side of a branch. It sears to prefer foraging when temeratures and humidity are high.

\section{Psendomyerma pallido $F$. Smith}

Until Creighton's paper (1950), P. pallida and P. Llavidula were racognized as separate opecios on the basis of the presence or absence of bleck spots on the base of the abdomen in fleridule. Creighton has synonyraiced Plavidula, since he has found that a nest series of sufficient longth will contain individuals with and without black spots on their gasters. Nest series from the Reserve also have shown these characteristics. 
P. paliida ms found in eight stations. The black pino Pottorbush association affords a great many Andropogon otoms which aro suitable nesting places for peliida. As a consoquence, the ant is found ebundantly in this station. It occurs comming in longleaf pino flatwoods and Loon scrubby flatwoods; occasionally in the sandhill areas and the slash pine flatwoods; and raroly in xerio hananock.

Because of its preforence for tall gress stoms as nosts, $P$. pallida was found nost often in the horbeceous stratum, but was also takon arboreally. It was absent from the other strata.

The nosting sites of pellide were almost always true twigs or were twig-like. All but a fer collections wore made from tall grass; a fer others were made from the twigs of pine and sorub oaks 3 and the ant can often be found nesting in the stems of planted bomboo. Seroral colloctions wore mede from twig-like small branches.

of 12 colonies taken, the number of workers varied frore 5 to 25. areraging 13. Of these colonies 7 contained no queons. (These small, queeniess ageregates y realiy be sections of a larger group centered around a queon. Soo Cremstogaster ashmeadi and . minutissima missouriensis) Eggs, larvae, and pupae are presont in all months, with a peak of abundance indicetsd in August. Winged forms were taken from the nests from August through November. No nost contained both males and fomales.

This agilo ant has a knack of disappearing bohind a grass stem or a twig when disturbed. Whon a nost is broken opon, many of the ants will romain porfeotly still until touched. Normily thoy oxhibit a moderate to considerablo above-ground activity. Several vorkers were found, evidently foraging, within a cocoon of dead bagrom (Threidoptorys ophemereeformis Heworth) hanging from a fetterbush. 
The eggs, larvae, and pupae of this ant are usually more or leso eegregated. A typical nest contained eggs and ome larve in the base of a grase atem, other larger larvae near the middle, and pupae and a for eggs near the top of the stem. Many times the queen is found near or at the top of the atalk.

As the Andropogon dies in the fall and the stems become drier and less habitable, the ants are forced down near or into the base of the stens, or Into portions of etems that have been broken from the plant but which are still supported by vegetation. Their abundance becomes somewhat less until the opring growth of grass creates new nesting itos. In thio respeot those ants, like Paratreching parnulg in marsh, show a seesonal variation in occurrence which is dependent on the scasonal variation in occurrence of the nesting site plant.

It might well be pointed out that the nature of the Pinus Eorotine-Dosmothamnus association, wich this ant occupies in tho most abundance, gives an advantage to these grass ster ants in the summer, just as it creates a dieadvantage for the ant when the Andropogon dies In the winter. During the height of the rainy seas on from carly July into August, the water levol may reach within inches of the soil surface, or even exceed it. Deep burrowing formo which cannot withotand prolonged periods of submergence vill be kent at a minimum or oliminated. A fev form, such as Iridommenex pruinosus and Formice erchboldy, can withstand the subwergence of their lover galleries, and undoubtedly eluctuate tho depth of their gallerios with the risc and fall of the water tablo. The grass stem ants, on tho other hand, remein relatively unaffectod by tho pater lovel change, are rree of competition for their nesting site, and at the same time are adepted to procure the abovo-ground food aupply. 


\section{Subfamily Mrmicinae}

\section{Pogonomymex badius (Latr.)}

P. badius is one of tho nost restricted ants of the Reserve as far as occurrence in plant associations is concernod. It roquiros opan areas in which to build its dorse-shaped mound, and only a for oituations suitablo in this respoct occur in the stations studied in the present problem. Xeric hamnock is preforred and nests ore found there comonly. P. badius nosts were taken occasionally to comonly in turkey oak, and occarionally in bluejack oak. Many neste are found on lawns, around gardens, and in firelanes. All of its nests were complete, domed craters. Characteristically, the areas around the openings of the nests are always bare of vogetation in well-ostablishod colonies. Uany of these areas are edged with charred pieces of wood, seeds, twige, and other debris. The charcoal rim of my of these mounds is a conspicuous feature of the nests. Wray (1938), giving an account of the ant in North Carolina, mentions that nests in that region havo the same features. Ho also gives a description of the internal structure of the nests.

Observations rore mado on a nest of this active ant boginning in August, 1949. The nest, which was situated in a lawn, had boon mored perhaps three feot indiately prior to the first observation. Surface temperature, temperature at throe inches, relative humidity, and the number of workars emerging from the nest within a period of two minutes were recorded daily for 8:30 A.M., 11:30 A.M., 2:30 P.K., and 5:30 P.M. Activity of the colony above ground never began before 8:30 A.M. and was usually completed within a few winutes of 5:30 P.15. In Fobruary, 1950, 
the nest oponing was again moved, this time only a foot. In each of these inatances of changing the site of the nest opening, it is possible that pome of the old chamber and gallorios vere continued in use.

Table IV show the number of Pogonomvrmex badius that amerged from the nest during a warm period in August on four succesaive days, and during four days of a cold period in November. On August 12, no ants were seon above ground. Although the tomporature this day was mild, the relative humidity remained at $100 \%$ and most of the day was rainy. Other colonies heve been noted to continue excavation during very light rain, but when the drops bocame constant, activity stopped. The ants show a tendoney to aroid high humidity, although can be soen on August 14, activity continued during 100\% humidity. Conversely, lowor humidities are correlated with the greatest activity. Howevor, when the humidity becomes very 10 w and temperature rory high $\left(50^{\circ} \mathrm{C}\right.$. or more) in June and July in midday, cessation of above-ground activity occurs. The temperature at three inches below the ourface was first rocorded on August 14. During the rest of August, whilo these temperatures wero being taken, the ante oponed and closed their nest at a three inch temperature of about $27^{\circ} \mathrm{C}$, as indicated in the table. In November, however, most of the temperatures were belov $27^{\circ} \mathrm{C}$,, and opening began at a three inch temperature of about $10^{\circ} \mathrm{C}$, whereas closing started at about $16^{\circ} \mathrm{C}$. Thresholds of surface temperatures were more obscure.

Besides the effoct of the temprature on the opening and closing of the nost, high humidity, as indicated abovo, soom to retard tho opening and spoed the closing. The ants oro olow to start work on mornings with a good deal of moisture in the air. In the ovenings, when the humidity rises, they are usually woll along in their closing operations when it 
MURGER OF POGONOLYRUMEX ACTIVE DURING A WARM AND DURING A COLD PERIOD

\begin{tabular}{|c|c|c|c|c|c|c|}
\hline dato & time & $\frac{t a n p}{3^{N}}$ & $\frac{\text { at }}{\text { sur. }}$ & rol. hum. & $\begin{array}{l}\text { no. in } \\
2 \text { min. }\end{array}$ & recourkas \\
\hline $8 / 12 / 49$ & $\begin{array}{l}0830 \\
1130 \\
1430 \\
1730\end{array}$ & & $\begin{array}{l}22^{\circ} \mathrm{C} \\
19 \\
20 \\
19\end{array}$ & $\begin{array}{l}100 \% \\
100 \\
100 \\
100\end{array}$ & $\begin{array}{l}0 \\
0 \\
0 \\
0\end{array}$ & $\begin{array}{l}\text { overcast } \\
\text { rainy } \\
\text { rasiny } \\
\text { rainy }\end{array}$ \\
\hline $8 / 13 / 49$ & $\begin{array}{l}0830 \\
2130 \\
1430 \\
1730\end{array}$ & & $\begin{array}{l}24.5 \\
39 \\
41 \\
22\end{array}$ & $\begin{array}{l}87 \\
57 \\
42 \\
94\end{array}$ & $\begin{array}{r}0 \\
178 \\
152 \\
0\end{array}$ & $\begin{array}{l}\text { cloudy } \\
\text { vindy, clear } \\
\text { clear } \\
\text { windy, clear }\end{array}$ \\
\hline $8 / 14 / 49$ & $\begin{array}{l}0830 \\
1130 \\
1430 \\
1730 \\
1800 \\
1830 \\
1900 \\
1920\end{array}$ & $\begin{array}{l}25^{\circ} \mathrm{C} . \\
30 \\
35 \\
31 \\
30 \\
29 \\
27 \\
27\end{array}$ & $\begin{array}{l}38 \\
39 \\
40 \\
24 \\
23 \\
23 \\
23 \\
23\end{array}$ & $\begin{array}{r}46 \\
50 \\
51 \\
100 \\
100 \\
100 \\
100 \\
100\end{array}$ & $\begin{array}{r}0 \\
180 \\
235 \\
204 \\
180 \\
68 \\
4 \\
0\end{array}$ & $\begin{array}{l}\text { clear } \\
\text { openod } 0945 \\
\text { cloar } \\
\text { rainy } \\
\text { clear } \\
\text { sunset }\end{array}$ \\
\hline $8 / 15 / 49$ & $\begin{array}{l}0830 \\
1130 \\
1430 \\
1730\end{array}$ & $\begin{array}{l}27 \\
33 \\
35 \\
32\end{array}$ & $\begin{array}{l}36 \\
49 \\
37 \\
30\end{array}$ & $\begin{array}{l}35 \\
25- \\
35 \\
62\end{array}$ & $\begin{array}{l}128 \\
288 \\
150 \\
136\end{array}$ & $\begin{array}{l}\text { activity starts at } 0830 \\
\text { clear } \\
\text { clear } \\
\text { closing starts at } 1730\end{array}$ \\
\hline $11 / 17 / 49$ & $\begin{array}{l}0830 \\
1130 \\
1430 \\
1730 \\
1735\end{array}$ & $\begin{array}{l}10 \\
16 \\
20 \\
18 \\
18\end{array}$ & $\begin{array}{r}18 \\
25 \\
27 \\
10 \\
9\end{array}$ & $\begin{array}{l}45 \\
35 \\
37 \\
75 \\
83\end{array}$ & $\begin{array}{r}48 \\
50 \\
52 \\
1 \\
0\end{array}$ & $\begin{array}{l}\text { clear, activity sluggish } \\
\text { moderately active } \\
\text { moderately active } \\
\text { sluggish }\end{array}$ \\
\hline $11 / 18 / 49$ & $\begin{array}{l}0830 \\
1130 \\
1430 \\
1715\end{array}$ & $\begin{array}{r}8 \\
13 \\
19 \\
16\end{array}$ & $\begin{array}{r}10 \\
18 \\
24 \\
8\end{array}$ & $\begin{array}{l}55 \\
25- \\
25- \\
65\end{array}$ & $\begin{array}{r}0 \\
44 \\
51 \\
0\end{array}$ & $\begin{array}{l}\text { clear, sunny } \\
\text { sundown, clear }\end{array}$ \\
\hline $11 / 19 / 49$ & $\begin{array}{l}0830 \\
1130 \\
1430 \\
1730 \\
1750\end{array}$ & $\begin{array}{l}7 \\
17 \\
18 \\
16 \\
15\end{array}$ & $\begin{array}{r}10 \\
17 \\
21 \\
6 \\
5\end{array}$ & $\begin{array}{l}75 \\
25- \\
25- \\
89 \\
100\end{array}$ & $\begin{array}{r}0 \\
25 \\
57 \\
3 \\
0\end{array}$ & $\begin{array}{l}\text { clear } \\
\text { sunny } \\
\text { activity moderate } \\
\text { closing starts at } 1715 \\
\text { sunset }\end{array}$ \\
\hline $11 / 20 / 49$ & $\begin{array}{l}0830 \\
1130 \\
1430 \\
1730 \\
1745\end{array}$ & $\begin{array}{l}8 \\
13 \\
19 \\
17 \\
15\end{array}$ & $\begin{array}{r}12 \\
27 \\
30 \\
11 \\
9\end{array}$ & $\begin{array}{l}65 \\
25- \\
25- \\
97 \\
100\end{array}$ & $\begin{array}{r}0 \\
100 \\
49 \\
28 \\
0\end{array}$ & $\begin{array}{l}\text { clear, sunny } \\
\text { quite active } \\
\text { closing starts at } 1730\end{array}$ \\
\hline
\end{tabular}


reaches $100 \%$. In addition, closing seoms to be influenced by the inoreasing darkness, and the nest was usually closed by sunset. Controlled laboratory experiments would have to be carried out to deterwine the importance of ach of these physical factors on colony activity.

A typical closing operation was carried out as follows Cortain of the vorkers started the procedure by picking up pellets of sand lying on the mound, and carrying the to the nest oponing. Some carried this sand botween their mandibles, and others pushed the pellots betwoen their hind logs. Once at the opening, the workers packed the sand into the orifice wall. The whole procodure not concontrated, and my individuals lost interest in their work. Little by littlo, howerer, the opening was made smaller. Some of the ants brought pioces of grass and small twigs instead of eand, and these acted as supports. During this whole activity, other ants were bringing pellets to the ourface. When the oponing was finally closed, thore remainod cmall area (two inches in diametor) clcarod of sand pellots which surrounded the pile of eand at the opening. Although the outside was closed, morement of the sand at the place of the opening indicated that the ants vere still packing eand into the passageway from the inside. The pilo of sand ovor the opening sometimes became very large, roaching on one occasion a hoight of ono-half inch, and diameter of ono-half inch. This turrot contained no pessegoway. Tho nost was closed in a similar fashion overy night, and in rainy woather somotimes remained closed all day.

In early December, the ants broke through the mound, over a period of days, in nine places. Fithin a few days all of the holos were plugged and the ants wore corging from the original opening. However, as has been noted, in Fobruary the ants closed their original opening, 
and used a new one approximately a foot from the former. Since the latter opening was in $1 \mathrm{am}$, the ants went about thoir charactoristic habit of cutting the grass around the oponing and covering the shoote left standing with sand.

A mating of the males and feralos from the same nest took place at about 10:00 A.d. on June 20, 1950. Vhile some workers were carrying on the normal nost activitiss of bringing seed husks and sand pellots to the surfaco and carrying soeds below, others were attending the mating individuals. These males and females woro two feet to one sido of the nest oponing, in an area about two feot in dianoter. Tho males ran very speodily over the ground, or else flev for short poriods six inches to a loot above the mating area. They vere probably equal in abundance to the combined numbers of famales and workers within the area.

Three or four males approached a given fomale at one time. Within a matter of seconds one of the malos had entered into copulation with the femal0. The period of copulation lasted up to one and one-half minutes. Bach famale tod with throe or four different males. Becauso the males woro so very quick in their movemonts, it vas difficult to toll whother a givon male mated more than once.

During the motings, the fast moving workers could bo observed pulling at the males wherever thoy happenod onto one. They pulled then away from the fomalos, even during mating, and wen a malo wandered back tovard the nest opening, ho was carried or pulled away. Probably the samo stimulus was involvod in all of these activities.

After each mating, each fomalo stroked hor antonnao with hor forelegs, and examined the tip of her abdomen with hor mouthparts. Whon several matings had takon placo, each ferralo bogan a slow Ilight upward. 
The les, which had boen flying swiftly around the mating aroa, gradually Plew away also.

The following seods have boen taken from nests of Pogonomyrmex badius: Amnelopsis arboros ${ }^{2}$, Phvtolacce rigids, Pinus sp., Conchrus grac1llimus (sandspur), Sabal palnotto (cabbago palm), Diodella toros (buttonweed), and contipodo grass.

The ants wore able to carry all of these seods, except those of the cabbage palm. One of the lattor soeds presented somerhat of a problem, although the ants wore able to carry it for short distances in their mandibles. Whon they had transported it to the mound, howerer, several ants bogan digging under it with their forelogs until a crater was formod with the sood in the conter. Imon the soed was removed for identification, the crator was bocoming deoper and the ants were making no progross. It was observod that ants can carry soods for at loast 100 foet. Cole (29328144), however, notoc the.t Pogonomycmex occidentilis in the wostern Unitod Statos carries seeds for as much as 0.7, 0.4, 1.35, and 0.25 miles.

\section{Aphoonogastar ashrueadi Bunery}

A. ashmoadi prefers the areas of the hoserve which offer xeromesic conditions in the subterranean stratum. It is found occasionally to comoniy in xeric bamock and Loon scrubby flatroods; occasionally in bluojack oak, scrub, and mesic hamock; and rarely in tissisey oak and bayhoad.

A. ashreadi is confined to the subterranean stratum. In all

1 Determinations of all seods were made by A. H. Laessle, Department of Biology, University of Florida. 
cases it nested in sand, and most of its nests were under litter. Ono nost, situated whoro thero wes no litter, had no rocognizablo erater and two nest openings.

The size of the nest is approximately the same as the closely related A. treatae. One nest contained 326 workers, 7 calloms, 250 pupae, plus ogga, larveo, and a queen. Winged forms have boon found in the nests in June.

The above-ground activity of this ant is moderate to considerable on clear, sunny days when the relative humidity is below $70 \%$. It has not been taken foraging when the temperature was below $20^{\circ} \mathrm{C}$. Along with other ants, A. ashmeadi shows a tendency to bocome very inactive above ground during the vinter. The form is carnivorous, and is attracted to raw liver; it has been seen carrying dead ants of other species, especially Odontomachus haomatoda Insularis.

\section{Aphaenogaster floridang U. R. Smith}

A. Ploridang was taken occasionally in turkey oak on the Reserve. In the Gainesville region, it was also taken in ruderal situations, such as open, sandy roadsides. Nests are either complete craters or rudimentary craters around small clumps of grass.

A. floridans is a fairly fast moving insect. Most of its forkging id done at night, but it is sometimes activo during the day, especially during overcast vother. It is attracted to molassos traps.

\section{Aphronogaster fulre Roger}

Within a given nest of fulve there is great variation in character proportions of the workers from the incipient to the mature 
colony. OL the pecinons sent hir from the Reservo, Dr. Smith (in litt.) says, "The smaller workers with more posteriorly rounded heads and longer antennae probably bolong to young colonies. As the colonies increase in size the lator workers acquiro shortor antenna and less rounded heads." Besause of this ohange in characterietics, it is important to recognize workers of an incipient colony, so that they will not be misidentified as a closely rolated form.

It can bo wentioned hore that individuals with shortor spinos, keying to rudis in Creighton's paper (1950), have been found on the Reservo, but are not includod because of their small nurber and uncertain taronomic position.

A. Lulve prefers the lover areas of the Reserve. They have bsen taken comonly in river swemp; occasionally in scrub, longleaf pine flatwoods, hydric hammock, and bayead; and rarely in Rutlege slash pine flatwoods, xeric hamock, and marsh. It tends to replace 1. ashmeads in the wotter areas.

Ants of this group have boen found in both the subtorranean and surfsco strata. Nosts wero equally abundant under logs, in litter, in fallen logs, under the mat of palmetto roots and trunks, and in doad stumps. They also have been found in and under logs and in the beses of living treoz. Logs which contain nests are usurlly in the last stages of decay. One nost was between the bases of palm fronds and the trunk of the palm in the debris gathered there.

of the 2 nests counted, the one from scrub contained 46 workers, 10 worker pupre, and 1 queon, while the other from river swamp contained 65 workers, 3 callows, 15 worker pupae, and 1 queen. Imnatures were in almost every nest collected. Liales were found in the nests in lay through 
July; no information was obtained concerning the femalos

The ants of this group are quite active. The vorkers are attracted to a mixturo of peanut butter and oatmenl. They have boen noted living next to nests of termites (Reticulitermes Llevines), and have been seen carrying lire termites in their mandibles.

\section{Aohsenogaster lamellidens Mays}

Only one collection of A. Igmollidens was made on the Volaka

Reserve. This nest, in roric hamock, occurrod in the baso of a broken limb which had docayed differentialy. In the Cainesville area, the author has collscted the species in mesic hamock in fallen logs. In the Great Smoky Hountains, Cole (1940:52) has found a for colonios "In vet rotting logs in a deeply shaded forest".

Although collections in other regicns indicate that lamellidens occurs usually in the surface stratur, its collection on the Reservo from the stump of a limb 5 foet above the ground places it in the arboreal stratum.

\section{Aohnenogaster mecrosping M. R. Smith}

A. macrospina wa taken occesionally in bluojack ask, longleaf pine and Rutlege slash pine llatrsods. All of its nests roro in the aubterranean stratum under 11tter. Its distribution on the Roserve shows a preference for pine growths.

This is a moderately active ant. On a number of occasions, it has been attracted to molesses. One nest countod contained 65 voriers, 10 worker pupae, and $I$ queen. Attention was dram to the neat by the cepture of individuals of this species in a molasses trap. Part or all 
of the 44 ants eaught in the molasses trap may have belonged to this colony.

\section{Aphronozaster texana Bmory}

A. texana nosts oecasionally in scrub, and rarely in longleaf pine Ilatwoods, xeric hammock, and mesio hammoek. Nests have been taken only from the surface stratum in wot to seturated loge in the last stages of decay. The habits of this spocies are much the same as those of fulve.

\section{Aphrenogaster treatal Forel}

Nests of A. treatae have boen found occasionally in Loon scrubby flatwoods, and rarely in scrub. Although it has been found in only these two plant associations, thero is no apparont reeson why it should not occur in other areas with relatively light leaf littor, as does A. ashmoadi.

All of its nests have boon found in the subterranean stratum under litter. One nest contrined eggs, 20 larvae, 81 pupae, 20 callows, 292 workers, and 1 queon. Two diplopods were renoved from the dirt surrounding the nest.

A. treatae is a moderately fast moving, timid insect. Workers have been noted carrying larvee of various kinds into the nests. A grasshopper nymop was readily aten whon introduced into a nest transplanted lato the laboratory.

This laboratory nest consisted of the queen and threo workers. The queen laid eggs within throe days of the time that she was placed in the nest. All of these egge were kept near a damp sponge in the nest, 
and were cared for by tho workers. The queen rested an the eponge, and paid little attention to the clump of eggso

A. treatge has boon takon from the Chicago area (Gregg, 1944) and fron Iowa (Buron, 1943), and Cole (1940:50) has the following to say concerning nests in the Groat Smoky Hountains "Invariably, it was found colonizing open woods (usually pine) or less frequently grassy fields and slopos. All nestr wore beneath otones of varying Bize, and each nest possessod a ingle entrance, either boneath or beside the stone, leading by a gallery to a series of large interconnected chambers deep in the soil.... In all cases, however, the ooll was rather moist." It 13 probeble that the "open voods" and "grassy fields and slopes" of the Great Smoky Lountains offer conditions oimilar to the open areas of the Resorve. Since there are fow stones on the Reserve, the ar: here must bo satibfied to use leaf litter to cover its neat opering.

\section{Pheidole dentate Nayr}

P. dentate nosts aro well represented in all of the stations on the Reserve except marsh. It was taken moet often in the better drainod areas, 28 woll as tho havmooks, river swamp, and black pinofetterbugh flatwoods. Colonies occur abundantly in scrub, Loon scrubby flatwoods, Pomello scrubby Platwoods, and river swamp commonly to abundantly in bluejack oak, xeric hamock, nesic hamock, and black pine-fotterbush flatwoods; comeonly in turkey oak, longleaf pine flatwoods, Plumer and Rutloge slash pine flatwoods, and hydric hanmock; oocasionally in bayhead; and rarely in marsh.

Over two-thirds of the dentate nests taken were on the 8011 surface, and, witl: the exception of one collection from a small branch, 
all others woro taken from sond, mostly undor litter. Nests under litter, and nosts in logs and sturne are preforred by 2 . dentata. The other nesting sites in which it wa found, in order of importance for the ant, ares

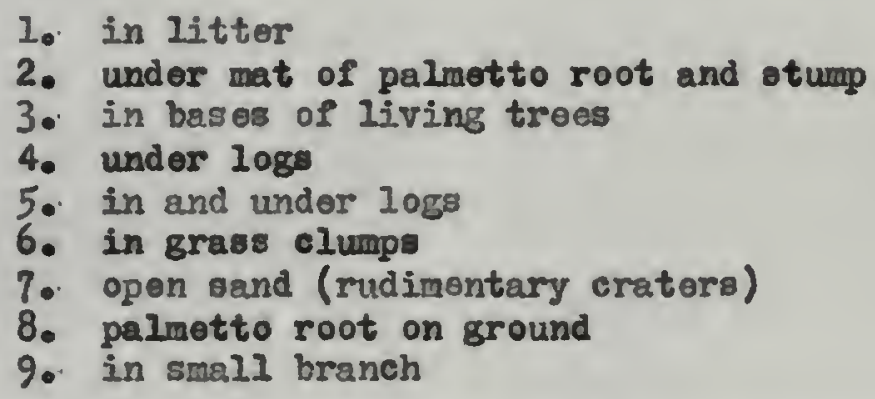

Other sollootions wore mado under moss on a saw palmotto root, and several records wero mado of nevts in fern roots.

In Gainesville, R. dentata wa found to nest equally often in loge and in rudimentary craters. On the Roserve, probably due to the presence of litter and at least some nood in almost all situstions, craters of this ant were soldom found. Evon though othar ants, such as Pozonozingriax badius wore ablo to build crater nesto only, P. dentata showed its preference for nests in rood or under cover of wood or litter, by aroiding the open arcas.

Nost wore rycordod in trood in all stages of docay, and in wood that variod from wet to dry. Most of the nests in logs or stumps were in pine, although a number wore found in brozdleaved wood. Often these nests wore under the bark, but a fer nests in sturaps axtended down into the root aystems. During the wet seasons, nests have been found several feot high in dead treo trunks.

Nests of this ant usually contain a large number of individuals. One rather small nost comprised 162 workers, 9 soldiers, and 1 queen. Inmature forms are presont all year except during cold periods. Finged 
forms have beon taken in flight in Way and June, and a dealate fecalo was recorded wandering in Fobruary. Reproductive form pupa were soen in the nests in April.

Hany times, especially during the rainy season whon the ground becomes very wet, the imuatures are brought to the surface and laid on or betweon leaves. On other occasions, in 108 nosts, the immaturee were scattered throughout the 108 without any sooming ordor. Sirilar nests, however, proved to have all the viss, larvae, and pupas in ono spot. During soveral poriods of cold weather, workers of dentate were the only anto carrying on conspicuous above-ground activity. A point which further indicates its adsptability to adverse conditions is that dentata is one of the fer ants which regularly forages in swamp during the periods of high water, when very littlo soil is above water, and all of the soil is saturated.

The feoding habits of this onergetic Phoidole are diverso. It is attractod to a mixture of peanut butter and oatreal used in manual traps, to liver, and to nolasses. These ants have beon soon carrying callombola and iorwitos. Whon a nest of Raticulitermes Llatioes was chopped into, thoy were almost inediately on the scone, carrying termites away. As tirae passod, more ants ontered into the ackivity. The tormites were either paralyzed into stillness or killod, or wore able to move only sligitly while boing carriod. Lost seomed fataliy injurod after thoy had been carried by cun ant.

The following have been taken in the nost with $P_{0}$ dentatis:

Isoptera, various spp.

Corrodentia

Orasema, possibly robertsoni (det. A. B. Gahan, U. S. N. $U_{0}$ ) (Gainesvillo) (Hymo)

Oraema robortsoni Gahan (dot. A. B. Gahan, U. S. N. M.) (Hym.) 
Orazems pupas wore in tho nests in Soptomber and Octobor.

\section{Pholdole dentigula H. R. Swith}

P. dentiguza is not a comon ant on the Roserve although it we taken in 8 of the 15 ntations. Its nests were found camonly to occasionelly in mosic and hydric hemuock; occasionally in scrub, Pomello scrubby flatwoods, Plumer slash pino flatwoods, xoric hamock, and bayhead; and a questionable record was mado on the basis of workers alone from Rutloge slewh pine flatwoods.

All except one neat, takon under littor, wero found in the surface stratum. P. dontigula preforred nests in logs and in the bark at the bases of living troes, but it wro also found in stumps, under litter, ani one colloction was made from fern roots. Nests in rood vore almost equally divided betwoen pine and broadeaved logs or atuans which ranged from moist to wot. lost of the nests vere in soft or welldocayod wood, but many nests vero backed by hard wood.

The number of individuals in the nests varied widely, although none vero large. An everage nest contained 85 workers and 17 ouldiere (including callors), and 43 vorker pupae and 7 soldier pupae. Most, but not all of tho nosts had a quson. Inentures wore present all year. Temales were found on the wing in July and in the neste in Soptember, and males waro taken in the nosts in August. Ono nowt containod only two workers, but had eggs and larvae.

P. dentiguia is one of the spocies with wich Solenopsis molosts has toen lound associated. In acdition to the Solenopsis, Paratreching parrula was taken with Pheidolo dontiguls from under littor. 


\section{Phoidolo, near Iloridana Emery}

Smith has compared specimens of this ant from Welaka with those of floridana in the U. S. National llus oum. He says (in litt.) that the Nelaka specimens "have been compared with specimens from the original serios and although close to floridana they aro not typical. Loridang has much more of the posterior part and side of the head, and thorax less heavily sculptured than your spocimens. The postpetiolo is also larger and less angulate on the side". The sculpturing and shapo of the postpetiole have becn found to vary to only a negligiblo degree on the Reserve. No specimens have been tekon on the Resorve which approach individuals of floridena collected by the author in southern Florida.

This Phoidole replaces Monomorium pharaonis, provalent in the Gainesvillo reglon, in and arowad the houses of the Rescrve. In nonsuderal areas, it shows a preference for turkey oak and bluojack oak, where its nests occur comonly. Nests aro also conmon in Pomello scrubby flatroods. This ant is occasional to common in mosic hamock, and has boen found rarely or occesionally in scrub, Loon scrubby flatwoods, longleaf pino flatwoods, Plumer and Rutlege slash pine flatroods, black pino-fotterbush flatwoods, xeric and hydric hamocks, and river swamp.

Nests of this form have been found most often in the surface stratum, but almost as many have boon taken in sand. It occupies a variety of nesting sites. In order of preference they ares

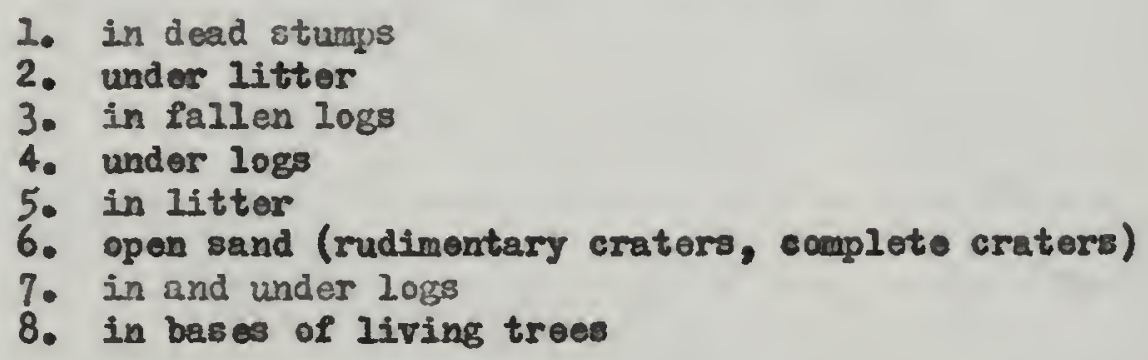


Ono colloction was do from under the nat of a palmotto root.

Nosts in sand have all showed a tendency to bo under cover of some sort. Although some nests had well-formed craters, all wero covered with one or seroral leaves. The rudinentary craters were all found against the foundations of buildinge, and it is possiblo that the ants here livod in crevices in cemont or undor picces of cement. Thoso nosts in rood were usually in wot logs or stumps, and although nosto occurred in wood in all stages of decay, moro were in the later stages. Hany collections were made under bark, and neithor broadloaved nor pine wood was preferred. Noste of this forn are not populous, and soom to be smaller than 2. dentigula. A nost, perhaps slightiy smaller than avorage, contained 35 workors and 6 soldiers along with imatures. Immatures probably occur all year, and ringed forms aro prosent during the sumer months. In some rests in rood it is difficult to delimit the boundaries of the colony. Individuals in those cases are found throughout tho $10 \mathrm{~g}$, and there is no single, compact nest group.

This modoratoly active Pheidolo is attractco to gresse in kitchons. On several occasions it was taken cating the peanut butter and oatmeal bait of mamal traps, and in othor instances it was found betwoen the septa of large wushrooms. Mr. J. C. Mooro found this ant on the Roservo in soveral fox squirrol nests. It continucs its foraging activitios into the night.

In one nest a beetle of the family Lothriidso was found assooiatod with tho ant in a stump in turkoy oak. 


\section{Phoidole metalloscons Emery}

P. metalzescens prefors the higher, drier areas. It occurs abundantly to comonly in turkey oak, Leon scrubby Platwoods, and xoric hamock; comonly in bluejack oak and scrub; occasionally in mesic hamock; and has boen found only rarely in longloaf pine flatwoods, but may occur more abundantly there. It is often found in firelanes.

Approximately oqual numbers of nests have boen found in the subterranoan stratum and in the surface stratum. Often, especially in turkey oak, nests have no crater, and the nest opening is entirely or partially covered by a single leaf. Some nests can be found in and around the root systems of herbs. The complete erater is characteristic of open ground, and in this situation iucomplete craters can also be found. Nests of this latter kind vary in outside diemeter of the crater from 2 to 3 inches, and in hoight from $1 / 6$ to $1 / 2$ inch; all of those nests have one opening. Lany other nests occur in sand under leaf litter, and some of thom mintain elomentary craters.

The locationo of nesta in fallen logs vary from near or on hard wood to vood merging with the substratum either the bark may otill bo intect or it way be absont. The wood may bo dry, or roist, or wet. A nest taken from a $\log$ in scrub contained 505 workers and 29 oldiors with 1 quoen. Imoturos occur the whole your. No infornation concerning the time of appearance of winged forms was obtained. One nest, taken in the raiddio of January, 1950, from a firelano, conteinod large chambers of vorkors within six inches of the surface.

This fairly last moving ant has a varied diet. It is attracted to liver and to molesses. Foraging activities axiond into the night. 


\section{Phoidolo morrisi Forel}

P. porrist is another of the ants which prefers the highor, nore open areas of the Reserve. It occurs occasionally to commoniy in turkey oak and xeric hammock, and occastonally in bluejack oak and Pomello and Leon sorubby flatwoods. Characteristically its nests appear along the dirt shoulders of roads, in firelanes, and in the areas around houses.

Ail of the nests of this species were in the subterranean stratus. Most of the nests were built in open sand, but some were constructed under leaf litter. Half of the nests had no crater, and the other half were built around a grass tuft or in lam, whore a rudimentary crater was thrown up beside the plants. Somotimes these craters were built beside a fallen log under which the colony could be found. Craters of merrisi buflt in the open were about 4 to 5 inches in diameter, and $12 / 2$ to 2 inches in height. A majority of nests had only one opening, but there were severel with two, and a few with throe, openings.

An unusually large nest of porrisi contained 3500 workers and 350 soldiers. An everage nest probably contains 1000 individuals. The irmature forms are absent from the nests fros late Decomber to February. Winged forms have boen taken in July. P. mosrisi is an activo ant, and colony employs numerous apoedy workers for foraging. Foraging activitios are carried on at night. It seems, however, to show a seasonal relationship in its abovoground activity. In the winter months foraging ceases almost altogether, and the ante remein in the nest, about three foot below the ground surface. Molasses attracts P. morrisi. It has boen seen to pick up eggs and larva, and even workers of Gromatogaster ashmeadi, but no interprotation of this activity is atterapted hero. 
5olenopsis porgancioj und Prrairoching alvenivags, as woll as a apecies of Diptera, have been found in nests of $\mathrm{P}$. morcisj.

\section{Pheidole ailifera (Foger)}

Smith (in lift.) fools that this is not tho typical form of P. Dilirera. Tho mane is tharofore used hore onity in the broad sonso. Nests of Dilifera have boon found only in rudoral areas, namoly in lawns and in orange groves, where its occurronce was frequent. AIl. nast3 wore complete crators which varicd in diaroter from 3 to 4 inchos, and in height from $1 / 4$ to $3 / 3$ inches. $A I I$ of tho craters had only ono nost opening.

E. pilifera, with its oxtromoly largo-hesded vorkers, was rocorded nesting vith Paratrochina aronivaga and Solenopsis porgandoi.

\section{Cardiccondyle eneryi Forel}

Toraging workors of C. morri wore taken occasionslly in roric haw ock and rarely in bluejack okk. Its nests in these situations havo probably all beon under littor, or perhaps in open sand. Srith (1944:36) states that the ants in Puerto Rico nost most comonly in sandy soil, but also in clay soil. Bosides tho abovementioned stations, C. enery has boon taken in the sand roads of the Reservo.

This smaII, slowmoving ant is attracted in great numbers to molascos traps. It continues its forging activities into the night. Females vere takon in flight in early Necember of 1949. Nests bo approximately the samo sizs as those of C. muda ninutior. 


\section{Cardiocondyla nuda minutior Forol}

On the basis of the fou collections mado of c. nuda minutior, firelanes and dirt roads, especially in high aroas such as xeric hamock, secen to be its proforred nesting situations. On several occasions the grillwork of an automobile which had just passed through the high graes that grows in the xoric homock roads was covored with workers of this form. It has boen collected rarely in longleaf pine flatwoods, and it was found foraging along the odge of a bayhead whore it abutted a sand road.

Liko Solenopsis glebularia littoralio, C. nuds minutior has been found only in uprooted pelmetto roots. These nests are on the under side of the root, rather doep in the line scalings of the wood.

The ant nests in swell colonies of about 20 individuale. Fewales were taken on the wing in August, and female pupae were obserred in the nest in the same month.

\section{Cardiocondyle vroughtoni bimaculat thoolor}

c. wroughtoni bimaculata has boen collocted comonly in turkey oak, and only raroly in Leon scrubby flatwoods and longlear pine Platroods. since it is common in turkoy oak, thero is no apparent reason why it should not be found in other of the high areas such as xeric hamock. Numorous nosts can be found abundantly in clumps of bamboo planted noar the buildings of the Resorve.

In turkey oak, nests of this ant are found most often in stumps of longleaf pine (Pinus pelustris) or turkey oak (Quercus lneris). All of those nosts have boen in or noxt to hard wood, with a littlo debris or softer wool near the nest. The species has also been taken froe logs 
of longleaf pine, either dry or moist; from the moist base of an Andropogon stem; and from an oleander twig in which the nest was partly in the conter of the stem, partly in the mood at the nodes, and partly under the thin bark in dobris. It nests in a very similar way in and around the nodes of bamboo. Nests can thus bo found in both the surface and herbecoous strata.

of 3 nests taken in turkey oak and 1 in berboo, that in the bamboo was the largest. These counted nests varied in number of workers from 21 to 43, and avoraged about 32 workers. The number of queens increased with the eize of the nest. The smallest nost contained I queen, while the others had 2, 4, and 5 queons respectively. All of the workers and queons wero in one or two contral chambers, and ware not difficult to collect. Immature forms ocour in all months. Females have been found in the nests in October, and a flight is rocorded on October 7, 1949. What seonod to be an 1nciplent nost without workers was observed in llay, indicating that porhaps the fomalos fly again in April or llay, or that the workers are not hatched out during the winter. This ant is moderately fast moving, and somowhat deliberate in its motions. Host of its foraging is done on days when the temperature is high (above $28^{\circ} \mathrm{C}$ ) and the rolative humidity is relatively 20w (below 40\%).

Cromatozaster minutiseima miosourionsis Emery Creighton (1950) lists the rango of this ant from Texas to Missouri. C. minutiosim minutissima is prosentod as replacing it from South Carolina to Floride and vestward through the Gulf States to Teras. However, spocimens from the Gainespillo region and from Welaka have been 
consistently identified by Dr. M. R. Smith of the U. S. N. M. as missourionsis. These locality rocords molko it doubtrul that minutissima and missourionsis aro subspocios of minutissing. Until it can bo provod, however, that thoy are variations of the samo form, missouriensis vill bo rocognized as a subspecies of minutiesima.

During the course of the present investigation, it was found that missouriensis prefers the more hydric situations, although it has also beon taken in the higher aroas. It nested counonly in Plumer slash pine flatwoods, mesic hammock, hydric hamock, and bayherd, proforring hydric hamook; occasionally in bluojack oak, scrub, Rutlege slash pino flatwoods, and xorio hammock; and rarely in Pomello scrubby Platwoods and river swamp. In the Gainesville region, the ant was found in very simlar situations.

C. minutissimg missouriensis proferred nests on the soil surface, but many nests were found arboreally. Soveral nosts wero also taken in the subterranoan stratum. The ant nested most often in fallen logs, bases of living troos, in small branches, in dead otumps, and under the mat of palmetto roots and trunks. It was also taken in the following places 8

under loge

in and under moss on a palmetto root

in a dobris-filled and well decayod Pinus clanse cono under litter

under the outer sheath of a dead flower stalk of Sarenoa repens

under moss at the bese of an oak troo

Nesting conditions varied from dry, in small branchos, to wot in logs buriod under litter. Other authors (Buren, 1943:289, and Colo, 1940, 46) have found the majority of nests in sand under stones.

A colony from a small branch in hydric hamook contained 208 
workers (including callows), 102 workor pupae, and 8 queeno. This colony wes a unit, but many colonies appear to occupy sevore.l different levols in a nesting plnce such as a log or the baso of a living troo. A typical nest, arranged anong dobris-fillod rogions alone 10 inchos of a log, occupied cavitios on the herd wood near the outside.

In a situation of this sort it is difficult, and porhaps really unnecessary for the present purposes, to be sure that ono is dealing with only one colony. One mas as what is the criterion which will distinguish a soction of a colony from a wholo colony. The presence of supernumerary queons in sore colonies of missouriensis makes it impossible to be suro ono is dealing vith a wholo colony when ono quoen is observed. Likeriso, hero and in the subgenus Acrocoelin, if a queen is observod, thero way bo other, quoenless parts of the colony in other places. Groups of workers have boen obsorvod in Cromstogaster, espocially in Acrocoelig, (and in other genore to some extent) with an abundance of imatures and no queen. Unless intercourse betwoen a queenless group and a group with a queen is observod, it would not bo clear whethor the quoonless group carries its eggs from a mother queen in another nesting place, or whether tho workers are independent and lay thoir own egess. In troating this situation throughout this study, ach physically distinct aggregation ie called a nost.

Colo (1940,46), in his roport on the ants of the Great Smoky Mountains, mentions a nest of missouriensis with only 47 workors, but 56 supernumerary queens. On the Reserve, immotures in the nest aro usually absent during periods of cold weather, but a few are present in most nesto all year. Winged form pupa havo boen found in the nosts in llay, and winged forms have boen taken through August. One instance of 
Penco pupa in October was observed, and in Jenuary males were taken on one occasion wandering about during the day.

This is a olow to moderately fast moving ant. It is attracted to molasses traps.

\section{Crematogastor ashmeadi Mayr}

C. asmeedi nests occur very commonly in all of the well drainod areas of the Reserve, and occasionally in the hammock areas and river stramp. Except for their occasional to common occurronce in longleaf pine flatwoods, thoy are found only rarely in poorly drained flatwoods. C. Iaeviuscule Mayr tonds strongly to roplace ashmeadi in tho llatwoods areas and in bayhead and marsh.

C. ashmeadi has boon taken abundantly in Pomello sorubby flatwoods; comnonly in scrub, Loon scrubby flatroods, and longleal pine Platroods; occesionally to comonly in turkey oak, bluejack aak, and xeric hamook; occasionally in mesio hemock, and river awamp; and rarely in Plumer slash pino Platwoods, black pino-fetterbush flatwoods, and hydric hamock.

By far the majority of collections were made arboreally, but other nosts wore taken in the surface stratum. Most often, the ant was found in small branches. The othor nesting sites in order of importance to the ant are as follows: twigs, galls, fallen logs, dead sturaps, and one collection was made in the base of a living treo. Most of the nesta in small branches wore found in either scrub oake or in Pinus clausa. Nests wore also taken from the logs of fallon sand pine, usually from under bark on the top side. Although the ant seemed to profer nesting ites in scrubby aaks, its presonce in pino logs and branchos indicates 
that its exclusion from poorly drafned platwoods is not due to an inability to live in pine.

The nosts in twigs were on scrubby arks, or else in grape vines. Those in scrubby oak gallo were usually in pendänt, spherteal galls. Some voro in other, variously shaped galle, espocially the type around stems; in these the ant occupiod the several differont compartments from which the gall masps had emerged. Nests were in ofther broadloaved or pine logs or sturngs, but were in all cases dry or moist. This proforence for dry or moist conditions in nosting sites supports the contention that this ant prefers the drior situations.

In tho Gainesvillo region, drier situation, emong then rudoral aress, wero also proforred. In the sume manner Cole $(1940,46)$ has found ashmeadi nesting in dry situations.

In the discussion of the life history of $\mathrm{C}$. minutissims missouriensis, it was brought out that on many occasions what may seom to be a colony of Acrocoelia my be morely a section of a larger aggregate, the true colony. It was pointed out that oach of these sections is here recognizod as a nest.

The number of workers contained in 18 nesta ranged from 4 to 425, avoraging 137. In none of these nests was a queen found. These nests had an avorage of 23 callow vorkers. The nest with the largest number of workers, taken in a smoll branch in Pomello scrubby flatwoods, containod 51 semales and 21 meles, while another nost of 185 workers contained no females and 38 males. Of those that contained winged forms, 12 were sex spocific, while the others contained at least three times as individuals of one ser as of another. The largest nest contained 220 worker pupae, whereas the other nests areraged about 25 worker pupee. 
Winged forme were found in the nests in July through Decomber. Single meles have been taken in January.

In times of excitemont, C. ashneadi extends its hoart-shaped gaster above its head, and runs quickly ovor the ground or the vegetation. Under normal circumotancos, this is a slow to moderately fast moving ant. Hony times when a nost is oponod during a cold period whon the nost is inactive, the workers do not wove, but lie with their bodies pressed flat against the surface to which they are clinging. Such is aleo true of the other members of the subenus.

In Soptember, 1948, collections in Pomello scrubby flatwoods showed a remarkable abundance of G. ashmerdi, ospecially in galls, but also in small branches. This large population was within a circumscribed area of the station, and may have boen coincidental with the gallo and the small branches becoming suitable for the ante. A seasonal high was also noticed in Loon scrubby flatwoods in Docember. During 1949 no such high was observed in oither station.

Although this subgenus is noted for its attendance of honoyderexcroting insects, thoy have boen observod carrying various kinds of dead insects into their nests. On one occasion an aggregate of C. ashmeadi was notod in a crotch of a sav pelnetto (Eerenos repens) frond; workers were carrying away parts of a dead grasshopper nymph. The workers have ropeatedly ventured into tho cyanide jar of a light trap in order to carry away insects. Thoy have also beon found, probebly as casuals, in fox oquirrel nosts by Mr. J. C. Moore.

Nests here beon obserred adjacent to those of the termites Kaloternes (iouteli3). In ono nest containing wingod form, a Diptera, resembling quite closely the melos of ashmeadi, found. 
Same of the workers found on the Reserve have a somowhat opaquo and slightly punctate thorax, differing from the usual shing, smooth thorax. One colony, the only one taken from under the bark of a 1 iving tree (Pinus palustris), containod vorkers with a lighter appearance than usual. The head and thorax are light bromn, Fhile the gaster is dark. The queen is all light brom, and measures $1.8 \mathrm{~mm}$. along the dorsum of the alinotum; other queons of $\mathrm{G}$. ashmeadi measure $2.0 \mathrm{ma}$. along the dorsum, and are all dark bromn or black.

\section{Cromatogastor coarctata rormiculata Emery}

The specimene listed here were assigned to Crematogaster yormiculate by Dr. H. R. Smith. The collections of this ant, which has its type locality in Los Angeles, aro the first Florida records.

Nests of this subspecies havo boen confined to two stations. C. coarctata yermiculata was collected occasionally in hydric hammock and river swamp. In all casos it was nesting arboreally, in most cases in twigs of sweotgum (Ifquidambar styraciflua) or some ono of the bay trees. Such twigg may havo a half dozen oponings to accomodato a colony. On ono occasion it was found neating in the crotch along the midrib of a Sabel palmotto frond undor tho dobris gathered thore. Other ents, especially Crematogaster ashmeadi and Paretreching parrula, are also found nesting on palmetto fronds.

The distribution of rermiculate in stations and nosting sites on the Reserve indicates rather strongly that it will elways bo found in moiat or hydric situations, and probably always above ground. In Gainesville, this form was taken in scrubby rlatwoods, in an area whero the plant association offored mesic conditions. 
It is possible that the nests of this ant oxtend into two or more twigs. If this is the case, each twig of such a colony contains only a section of tho whole colony. As explained before, each soction is troated as a nost here. Ono very lons twig seomed to contain a whole colony. A count of this colony yioldod 1085 workors, 162 worker callows, 7 roproductive and 710 vrorker pupae, 25 roproductivo and 221 worker larvae, and numerous eggs. The prosenco of roproductire pupao and larvao in the nest, taken in July, indicates that ringed forms would soon be prosent. Winged forms woro taken in another nost in ariy october. Tho habits of rermiculate are much like those of ashreadi.

\section{Crematogastor lacriuscula llayr}

C. Leviuscula prefers to nest in the poorly drained flatwoods aros of the Reserve, and in the retter areas of hamock and of seasonally Plooded plant ascociations. In this ray it tends to roplace G. ashmeady, although there are areas of overlap in the distribution of the two species, especially in longleaf pine flatwoods, and in mesic hamock.

c. Ieeviuscula was found abundantly in Rutlege slash pino flatroods and in marsh; comonly in longleaf pine flatwoods, Plumer slash pine flatwoods, hydric l.amock, and bayhead; occasionally in blucjack oak, and mosic hamock; and rarely in turkey oak ard xoric hamock. Its absenco from black pine-fetterbush flatwoods be due to the scarcity of loge in that station, but it also dopend on the relative openness and consoquent high rate of evaporation and prolonged dryness of the area. Nests of locviusculas pore found in all strata except the subterranean, most often arboreally, and loast often in the herbaceous stratum. Small branches and fallen logs are the most preferred nosting sitos. 
C. Inoviuscula, however, uses small branches less than half as many times as ashmoadi, whoreas it nests in fallen logs much more often than ashmeadi. In order of preferonce othor nesting sites in which laoviuscula has boen found are: twigs, dead stumps, carton, sawgrass flower stems. Single collections have boon made from an Andropogon stem, a driod loal of Sesittaria botween sopta, a Plower stalk of Sabal palmotto on ground, and from under pine needle litter on saw palmetto frond two foot abovo ground.

In a majority of the cases, the nosts in logs were in or against hard wood, but sone nests were in softer wood. Nests woro in logs of all stages of decay, from those merging with the soil to those in which the wood was in the first stage of decay. Some nects were under the bark of Pallen logs. Nests of carton were observed on occasion in the eawgrass (19ariseus jamaicensis) markh, but always on a florer stalk of sargrass; In these cases the nests occupied both the carton and the flover stalk. Never was the carton portion of such a nest far above tho water surfaco. In the marsh grass (Spartina bakeri) marsh on Buzzard's Roost, carton nests wore abundant. Excopt for a for laeviuscula in twigs, no other nesting site was observed to be occupied by ants in this marsh. Nests are usually one or two foet above the base of the Spartina clump, shaded by the tops of the grass blades. Each nost in marsh grass binds together a number of grass blades, usually the middlo dozen or 80 of each grass clump, and is hold up by them. Nests are quite large, measuring, on en avorage, 12 inches vertically and 4 inches horizontally. One nest measured 20 inches vertically and 6 inches horizontally. They are constructod of plant matorial, ususlly bits of leaves, togother with large sections or whole leaves of maple or wax myrtlo curled around the 
supporting grass. The nests are quito moist on the inside, but are always dry on the outsido. Several nests, built in the crotches of shrubs, oxtended from the carton into the adjoining hollon stems.

Nests of C. Iroviuscula are numerically about the same size as those of $\mathrm{C}$. ashmordi. The range in numbers of workers in the 7 nosts counted was from 16 to 300 , averaging 128. None of those nosts containod queons. Nosts and sections of nosts are considerod synonymous here in the manner discussod under C. 2shmeadi. The cold spolls on the Roservo $80 \mathrm{~cm}$ to be coincidental with the absence of in ature forms in the neste. Reproductive pupa appoar in the nests in April, and winged forms havo beon taken in June through JuIy, and again in Octobor through December. Only 2 out of the 10 nosts from which wingod forms were taken, contained both malos and fomalos.

On June 27,1948 , nest was observed in Rutlege slash pino flatwoods from which excited workers woro emerging and hastily running along the Iav shrubs eurrounding the twig nesting site. Along with the excitod zorkers wero males, evidently ready to make a flight, although no malo wae soon to fly. A nest brought into the laboratory on November 26. 1949 contained males which imediatoly atterspted to wander from the nest, although no flight obsorved. Tho males and attendant workers aggregated under the bucket in which the carton nost had been placod. Perhaps this restleasnoss was proflight activity, or was worely due to overexposure of the nost to sun with a consequent chango in temperaturo and relative humidity in the nest. (It is possiblo that in natural conditions a sharp onough change in the physical conditions of the nest may oroke flight.) The noxt day the nest was placed orer water in an attempt to keep the ants in their nost. On November 29, the los were 
noted investigating the onds of the cut marsh grass, but no flight took pleoo. Beczuse of their reetlossness, a largo number of males had fallen into the vater and drouned by the noxt day, and observations wero discontinuod.

Tho habits of morement and fooding are wuch like those discussed undor C. ashmeadj. Doad insocts havo boon found In nesto of C. Iseriuscula, and the ant is attracted to molasses traps. On ono occasion workers vere secuningly attending veale insects on a paIm frond. Nosts have beon noted near nests of terwites, tho workars of each freely intormingling. They wore seen to stroke tho tormites with thoir antennae and palpi on a.ll parts of tho termito's body, but mainly in tho hoad and thorex regions. Small mites have been found on the antennae of sovoral workers. The 8ize of many individuals in marsh 20 striking $1 \mathrm{y}$ larger than that of those in other plant ansociations. Total body longth ranged in one nost from $3.0 \mathrm{~mm}$. to $4.8 \mathrm{~mm}$, whereas workers from other stations range from $2.5 \mathrm{man}$. to $3.3 \mathrm{~mm}$. In total body length.

\section{Crematogaster linoolata (Say)}

Croighton $(1950,213)$ notes that C. Iineolate is found the farthest 8 outh in tho Appalachian Highlands of northorn Goorgia, and that an altitudinal difference soparates linoolate from the subspocies subopaca. C. Iineolata is reported to have its rango at low to moderate olovations In the South Atlantic States, as well as to the vest and north.

$$
\text { Specimons which are labolied C. Iineolote, sont to the autho: }
$$
by Dr. Smith, koy out to C. Iinoolata Bubopeca in Croighton's koy. On the other hend, those specimens which were taken on the Roserve can be assigned to Iineolats on the basis of his key. According to the 
distribution Creighton cites, subopses, and not linoolata, should occur here. Since it will not be clear what form of the species lineolate occurs on the Reserve until epecimene of lineolats and subopece have boen examined, the name linoolata will bo used here in the broad sense. c. Iinoolata was taken in only throo stations. It occurs comnonly in Porello scrubby Platwoods, and oceasionally in Loon scrubioy Platwoods and xoric hammock. Nests have been found in almost oqual abundance in the surface stratum and in the subterranoan stratum under Litter.

Its nesting sites have boon approximately ovenly dividod betweon nests under litter, in litter, in fallon logs, in dead stump, and in sall branches. The nests in logs and sturaps were in oak for the most part, but some wero found in pine. The relatively fow nosts in pine sets Iinoolata apart from the other members of the subganus on the Reserve, but the difference may be duo to the distribution of the species in stations where the main troes forwing logs and stumps aro rather than pine. In this rospoct it can bo noted that linoolata follows the distribution trend of ashmoadi rether than that of loeviuscula, occurring in the better drained areas of the Reserve. Cole (1940,47) indicates, as do the abovo observations, that this spocies lives as often in the soil as in rood. He mentions that nests under stones loosely resting on the soil wero a favorable nesting site.

One rest from Pomello scrubby fletwoods contained 184 workers, 3 callow workers, and 35 morker pupas. No queon was taken. Cold verther, as it does with the other speoies of the subgenus on the Reserve, soems to inhibit tho production of eggs. Pupse of males and femalos were soen In nests at the end of larch, and males were takea in the nost in liay. 
No information concorning vinged femalas was obtained.

G. lineolata has much the same habits as the others of the subgenus on the Reserve. It is a moderately fast moving ant. Bocause of its distribution on the Reserve, it was taken in most cases when the terperatures wore high and the relative humidity 10w. It was observed attonding aphids, and probably also uses insocts as food.

\section{Monomerium floricola (Jordon)}

One specimen of this species was collected wandering on a eawdust pilo in turkey oak. This introduced species is well distributed over Central Anorica and tho Wost Indies. Whooler (1908,128), writing of the ants of Puorto Rico and tho Virgin Iolands, statos that these ants are "Gomon in Tillandsias, under bark-scalos of troes and in hollow twigg. All the fomalos vere apterous...."

\section{lonomorium minimum (Buckloy)}

14. minimum taks taken occsionally in only one station, nsmely turkoy oak. It was, howovor, found also in firelones, and was one of the more common occupants of the latter aroes. In most cases this ant nested in craters, either incomplete or complete, but some nosts were found under very light litter. The craters, all with one nost opening, varied in diameter from $21 / 2$ to 4 inches, and in height from $1 / 2$ to $13 / 4$ inches.

In the Gainesville rogion, minimum found nosting for the most part in logs, or under logs or other cover. It seoms to be vell distributed throughout the United States.

During the work of bringing pellets of sand to the surface, 
this modorately fast moving, diligent ant omploys many workors, and theroby givos the nost the appearance of bustling activity. By comparing a vial fillod with a knotm number of ants and another filled with an unknown numbor, a total of about 3000 workers was ostimated for one nest. Several termitos wore taken with thie colony.

\section{Solonopsis geminate (Fabricius)}

The close morphological resemblance of this ant and S. rufe is discussed under the latter ant. Since the lack of the mososternal spine in this form soems to be on untrustworthy character to differontiate it from rufa, the darker oolor of geainata has beon used here to distinguish the two forms.

S. geminate was found in nino stations, but it was taken commonly only in Leon scrubby flatwoods. Occasional collections vere made from turkey oak, bluejack oak, Pomollo scrubby flatwoode, longleal pino flatwoods, xoric hamock, hydric hamock, and river swamp; and ono nest was found in scrub. Firolanes also afford a favorablo nesting sito. In tho Gainesville region it was found more commonly, and was also taken in mosic harmock.

On the Reserve, geminata has for the most part occupiod the subterranean stratum, but has also boen found in tho surface stratum. Host of its nests are asymotrical, rudimontary craters, or are in sand under litter. Othor nests were found in incomplete craters, complete craters, in a palmotto root on the ground, and under a longleal pine log. This last colony had produced a orater at the side of the log.

The nests with incomplete and complete craters were very likely incipient nests, or nests with small numbers of individusls. As these 
noste grow in size, the several grouped crators fuse to form a large, rudimentary crater. Many of the rudimentary craters, on the other hand, are begun around a cluan of grass which soon bocomes buried under the sand of the crater. Some rudimentary craters are built in the form of a string of craters, Bomotimes up to elght foet in length. One rudimentary crater was bogun around the base of a scrub oak, and was composed of sand, leaves, and omall pioces of rootlets. Rudimentary craters havo beon observed ranging from 4 inchos to over $11 / 2$ feet in diameter; from 1 inch to almost $1 / 2$ foot in height; and in number of nost oponings from 1 to 20 or more.

This "firo ant" is moderately agile, much like misa. It has been attracted to mamal traps baited with peenut butter and oatmeal. Small soods, such as alycoclover and carpetgrass, make up part of ito lood, but the ant's small size makes larger soods too difficult to carry. The workers also derive honeydew from aphids on the roots of plants near their nest.

Winged forms have been observed in June and July. Imatures appoar most numerous in the summer.

\section{Solonopsis rufa (Jordon)}

This form has boon listod by Croighton (1950) and provious authors as S. geminate rufe. Creighton, hovever, points out that the charactors used to separate geminata from rusa have been given more prominence than they deservo, and that the character of the mesosternal spine in rufa is more valid for the ssiatic specinons than for those from the United Statos. In America mufa and geminata are found in practically the same areas, making it irpossiblo to troat rufa as a 
goographical subspecios. On the other hand, rufa and ganinata are found to intergrado, maling it difficult to treat them as soparato spocies. Creighton (1950:232) says "In this country sufe bohaves as a color varioty and shows no geographical distinctions. I have retained it as a subspecies bocause this bohavior may be a result of introduction." Evidently there is material which ha come to Croighton's attontion that makos him believe that rufe and geminata aro not synonymous. With doubt still existing as to tho taxonomic status of rufa, it is hero belleved wiser to treat it as a soparate species and not involve the geographio connotation of a subspocies.

specimens of rufe vere found rarely in turkey oak and longleaf pine flatwoods, and occasionally in Plumer slash pine flatroods. Colonios have boen taken from both the surfaoe and subterranean strata. Neste are found most often with rudimentery craters or under litter in sand. One nost was found in the under side of a turikay oak Quercus laevis) log. Part of this last colony was in the log and a lesser part in the sand under the $10 \mathrm{~g}$. The rudimentary creters or mounds may reach a diameter of 2 feet and a height of 1 foot, with numerous nost openings. To build these nests S. rufa sooks the more open areas. For aramplo, the nost in lengleal pine flatwonds was partly in the flatwoods proper and partly in a firelane which was cut through the flatwoods. S. cufe has also been takon nesting in ruderal bamboo.

In the Gainesville region the hamocks provided nesting sites for this ant. Its abundance around Gainesville was higher than on the Reserve, probably because of the more open nature of the ground. There is also the possibility that, because it is a "tranp" form, it has spread more widely in the rosidential districts and their surrounding areas, 
than in the less comercial area of the Reserve. In the Gainesville region, small craters wore often seon built around grass elumps. As the nest grew and moro sand was brought to the surface, the grasa was buried.

S. rufa is a moderately fast moving ant. Sweeping with an insect not across Iow vegetation has, on several occasions, yiolded spocimens of this form. Flights of minged forms have boon observed in Nay and October.

\section{Solonopsis globularia Iittcralis Creighton}

s. Glebularia littoralis is one of the fer ants eollocted more than once which occur in only one plant association of the Resorve. It was found occasionally in black pino-Petterbush Platroods. In Gainssville, the ant was confined to the open, almost shrubless fletwoods which are cormonly used as pastureland in that area.

The nests on the Reservo were found to be only in the ourface stratum. Typical nests were in palmotto roots throm up on the soil surface. In the palmotto root the nest was built betwoen the overlapping flakes of the bases of fronds, and was on the under side near the soil. Ono nost was found in a grass clump, part of the nost boing in tho roots of the plant, where the queon was located, and the rest boing in the lower stoms. In Gainosvillo, the ants were taken from under the bark of nowly cut pino logs, and from nests built in sand and covered by small shavings of wood and pine noedros.

One nest, taken in the black pino-fetterbush association of the Reserve, containod 46 warkers and 1 quoon, along with immature Porms. Wo information as to when the sexurl forms appear in the nosts was obtained. 
S. Elobularia littoralis is a moderately fast moving ant. It axtends its above-ground activities into the night.

\section{Solenopsis minutisain Enory ?}

The taxonony of this swall, insignificart ant has boon one of the most confused of the ants of tho Reserve. Sinith (in Iitt.) said specimeno "agroo very woll with specimens collectod in Haiti and rocorded by Whoolor and liann....as pelinx Forol....Please do not consider the dotermination final as your spocimens have not boen chec'sod vith typos or with the original description." Othre specimons wore sent to Croighton, who was cognizant of Smith's dotormination. Ho wrote that in his opinton the specimons, which were the same that had beon dotercined pollux by Smith, wero minutissina Emory. He saye (in litt.): "Although I have not boon ablo to compare your spocinens tith typo material of minutissima, thoy agree so porfectly with Emery"s figuro and description of that species that there is littlo room for doubt on this point. The head of minutissima is more elongato than that of pollux and is narrowed bohind. There aro soveral other differences which distinguish the two epecios. Your specinene agree on every count with minutiseims rather than with pollwx..... . mentissing was originally described from matorial taken in Buenos Aires, Argontina. Tho spocios volid, thereforo, be mach moro likoly to ostablish itself in northern Florida than would a otrictly tropical form." In another lctter Creighton indicates that there is como doubt in his mind as to whother minutissimg should havo beon synonymized with lavicops. Ho says specimens frove the Reserve may possibly be 2aovicons, but he thinks it vory likely that thoy are minutissima. From still another aspoct, Brown, from a comparison of workar types, bolieves 
that minutissima and Smith's longicope are synonymous.

This ant seoms to prefer the mesic and hydric areas of tho Roserve, although it has boon taken in tho bottor drained stations. Nests wero occasional in turkey cak, bluojack oak, scrub, Pomello scrubby flatwoods, Plumer slesh pino flatwoods, mesic hamock, hydric harmock, and bayhead; and raro in xoric hammock and rivor swanp.

$\Lambda 11$ nests occurred in the surface stratur, mostly in the beses of living troes. The trees most proferred vere slach pine (Pinus elliotti), probably because of the high relative humidity and low rate of oraporation usually around theam. The ant was found also in longloaf pine (Pinus pelustris) in xoric hamock and bluofack oak, and once in wator oak (Quercus nigre). All of these nests vere at the base of the tree in the bark below the soil or litter surface; all were wet, and usually containod some debris. These nosts were in "Boctions" as discussed under Cremstogastor minutiesima missourieneis. Other nests were found in fallen loge and under the mat of a palmetto root.

A count of 3 nests yielded a range in the number of workere from 22 to 39, averaging 29. These numbers aro, in all likelihood, aller than is characteristic of an average nost or soction. Irmatures vere prosent in the nest in all parts of the year. What are believed to be reproductive form larvae wero found in the nest in April. No further information concerning the winged form was obtained.

The movements of this ant are even slower than those of $\mathbf{S}$. molesta. Whonever a nost was broken inte, the workers always realned motiorless for a fer seconds, perhaps long onough for the student to ovorlook them. As in the case of the Ponerine ants, which blend with their nestins sites, these ants are many timee given avay by tho presence 
of their white imatures.

\section{Solenopsis molosta (Say)}

Cortain of the specimens included under this heeding differ somewhat from the meavuremonts given by Smith (1942) and Hayes (1920). These spocimens are proportionately smaller than those described by these authors; they are also smaller than other specimens determined as polesta takon from the Reserve. Smith 2ists the worker length of polesta as $1.8 \mathrm{~mm} .3$ Hayes gives the length of the worker as $1.5 \mathrm{~mm}$. to $1.8 \mathrm{~mm}$. This last measurement is much closer to that of the range found on the Resorvo, whore workors varied from $1.45 \mathrm{~m}$. to $1.8 \mathrm{~mm}$. If these opocimons all ropresent the same opecies, it is possiblo that the difforence in length can be attributed to differonces in the technique of measurement, but it would be ovident that molesta workers have a wide rango in total length.

5. molesta finds its most preforred nesting eites in mosic or somewhat hydrie stations. It was taken abundantly in mesic harmock; comoniy in ccrub, Plumor slash pine flatwoods, and hydric hamock; occasionally to comonly in Panello serubby flatwoods, longleaf pine Ratwoods, and bayhead; occesionally in turkoy ak, bluojack ark, Loon scrubby Patwoods, Rutloge slash pine flatwoods, black pino-fetterbush flatwoodo, and xeric hamock. It is poseiblo that it vill also occur in marsh and seramp.

Nosting bites of molesta aro preponderantly in the surface stratum of the Reserve. Only one nest was found in sand. In the Gainesville rogion, however, approximately half the nests were constructed in sand, eithor in the open around grass clumps, or under some sort of 
cover. Colo (1940:41) montions only nosts in sand for molesta in the Great Smoky Mountains: "Tho indopondent nests consistod of a very for tiny chambers and galleries lying very noar the soil surface just beneath the cover of stone or rood." In seoming contradiction to the observations on the Reserve, Cole found molesta nosts only in dry grasey areas. It is likely, howorer, that the ant makes use of the nosting places available in those aress in which it finds itself. Where thoro aro no logs in the right stage of decomposition, it lives under stones or other material, and where thero are favorablo nesting sites in wood, it makes use of them.

In order of importance to the ant, the nesting sites in which molesta has been found on the Reserve aro as follons: basos of living trees, under of palmotto root, in dead stump, in fallon log, in palmotto root on ground, in and under litter. It has also boon found in the base of a grass clump, under sphagnum at base of live oak, and under sphagnum on sar palmotto root. Cases of lestobiosis have also been observed.

The majority of S. molesta nests in rood on the Reserve vere in sort, wet wood which was deceyod to fine debris. Those nests in Baw palmetto roots were usually betwoen the root and the basos of - loughod-off fronds where there wes quite a bit of dobris; as a rule, moss covered the roots. Nests in the beses of living troes were all in the bark bolow the soil surface, in a position where there was a great deal of moisture. Nests in fallon logs and stumps wore found equally in pine and broadleaved (especially oak) rood.

of the three nests counted, the number of workers ranged from 60 to 100, averaging 78. None of thaso had a queon. Nests which soewed 
to have at least 200 individuals have been soon. S. molests soom to nest in "sections" as discussed under Crematogacter minutissima missouriensis. It offors omowhat the same problem as Missouriensis, since it is small In size, and on many occasions can be found in the bases of living trees, ospocially pino. Soctions of a nost in the bark at the base of a troo may range almost the whole distance around the circumference. Hayes (1920:

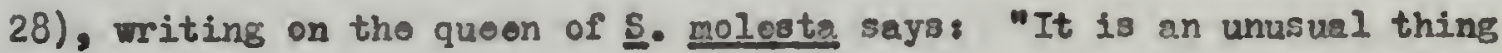
to find a queen in out-door nests, and the number of queens in a colony, when found, vary from one to many. In a aingle instance 26 fertile, or at loast wingless quoens were taken in a colony containing a large number of workors and imature forms." In an attempt to explain tho absence of quoens from nests in the field, Hayes states further that "Tho lifo of a queen under artificial conditions is very short. None vere able to live for an entire sumer, or even be carried over the rinter.... [but] Queens were found early in lay in outdoor nests, indicating that they will live over an ontire winter at loast." Hayes makes no mention of the point that his nests be on?y sections of complete colonies, and consequontly have no quoen. It is certain, hovevor, that quoons of S. molesta are not as asily obtainable as queons of oertain other species.

The workers of this ant are small and move slowly, and, whth thoir palo color, are difficult to seo against light beckgrounds. Wingod forms hare beon observed in the nests in July and Auguat, and inmatures aro present in every month.

Following is a list of the ants with which S. molesta has boen found nesting: 
Paratreching aconivaga, with Solonopsis pergandej Crematogaster alhmeadi

Aphrenogaster Pulve

Pheidole dentigula

On February 22, 1947, In the Gainesville rogion, a nest taken from around a grass clump in turkey oak, in which the ants were perhaps attending aphids, contrined a nymph of the family Viridae (det. R. I. Seilor, U. S. N. Y.) (Hemiptera).

\section{Solonopeis pergandei Forel}

S. pergander is the least common of the ants of the subgenus Diplorhoptrum on the Reserve. It taken occasionally in turkey oak and xeric hanmock, and rerely in Leon scrubby flatwoods and mesic hamock. This distribution indicates a preference for the botter drained areas of the Res erve.

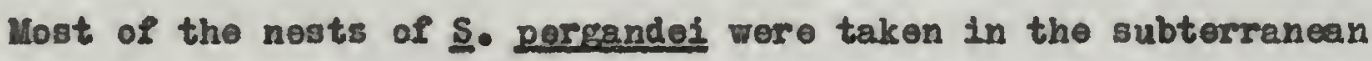
stratum, but the ant was also found in the surface stratum. It was found most often in nests of other ants. Other nests were taken under Iftter, under reindeer moss, and under the bark and in the wood of wet, fairly Boft laurel oak logs. Nests of thie ant in the Gainesville region vere more numerous than in Wolaka, and were built around small plants, clumps of grass, and ono was found around the base of a mushroom. These rudimentary noste a.ll containod four or fivo openings.

S. pergandei, as mentionod abovo, has boen notod to exhibit lestobiosis in nests of Paratreching arenivaga and Pheidole morrisf. Groups of the Solenopsis were found about a foot below the soil surface in the dirt of these nests. In several instances, $\mathbf{S}$. molests was taken along with perrandei in Paratreching nests. 
S. pergandoi is slow moving, and palo in color. These attributes make it difficult to detect, since it lives on palo colored sand in most cases. What are thought to be females of this specios have been taken in Auguat.

\section{Solenopsis picta Emery}

Tho distribution of S. picts in tho Welaka Recervo is poculiar in that it occurs in 14 of the 15 stations rorkod, but in nono does it occur with a high degroo of relative ebundence. It tas found ocsasionally to conenonly in bayhoad; occarionally in all other stations axcopt black pine-fotterbush flatwoods, roric hanock, river swam, and reh. It was absent in rsh, and occurrod rarely in the other throo stations. Its distribution is more closely allied with the arboreal stratun than with any station or group of stations.

Tho greatert number of colloctions wero in tho arboreal etratur, but several wore also mado in the surfacc stratum. The wost comon nesting sitos, in order of preference, are as follows: small branches, twigs, galls, and fallen logs. The ants vere sleo found under the mat of a palretto root and in the base of a living tree, and what may have been a nest was recordod from under litter. Although nore colloctions were mado of nests in wood of broadleavod treos, many colloctions wore also mado in pine, and the margin is not enough to indicate a preference.

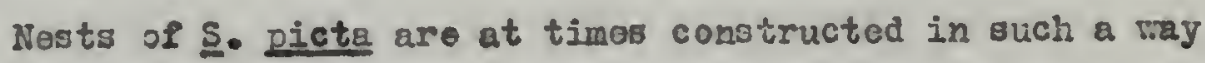
that they might be intorproted as being "sections" as discussod under Crematogaster minutissims missouriensis. Ono such nost in a small branch contained 13 workers and no qucen, while another in a gell contained 10 
workers and no queon. In the caso of the latter nest, it is possiblo that the rest of the colony was in a nearby gall which contained a queon with 48 workers. All othor nests counted contained ono queen each, In two small nests, thero wero 7 and 8 workers, rospectivoly from a grass stem and from a shrub trig. One nest from a twig in mesic havock contained 225 workers, while another from a twig in scrub contained 555 workers. Winged forms have boen taken in July.

S. picte is rather slov in its morements. It has been taken nesting very close to paratreching parmula in a sar palmetto root, perhaps giving an example of lestoblosis. The Selenopsif has also been taken with termites. Mr. J. C. Moore, working on the fox squirrels of the Reserve, has found it in the mamal nests. He records that one such fox squirrel nest in which ants ware found was $90 \%$ Spanish moss and well-soaked by frequent rains at the time of the collection. He states (in litt,) that "Cortain beotles, lepidopteras, and stratiomyid fly larvao were much more abundant than the ante in the rotting interior."

\section{Itrcrnecina americans Drery}

Only one specimen of this abt, from leaf litter in serub, was taken during the study. Further search failed to discover the nesting site.

Grogs (1944:462) has found americana rare in the Chicago region, and Buren (1943:290) libts it from Iowa. Colo (2940:40) sums up its habits in the Great Smoky Hountain in the following sentences: "It has been found only in very moist habitats, where it lives in small colonies and constructs littlo nests in wet rotted hollow twige, under dense asses of moss on loge on stones and beneath small stones. It was 
Found to bo a rathor comon representative of the moger ant fauna of the buckeyo-basswood forest. Hany of the colonies consisted of only 12 to 20 workers. The nests are of a very superficial nature and the chambers aro generally those natural crevices which may be accosaiblo. The vorkers are extremely slow of movement."

\section{Leptothorax porgandei Ploridanus Eraory}

L. pergandol floridanus occupiod eloven stations. Although it profers the higher, drier plant associations, it was taken eoveral times in Iow Platwoode and Lor hamocks. Nests were, howerer, found to be excluded from the seasonally flooded areas. It is interesting to noto that the subspecios has boen collected most comonly in the low black pino-fotterbush flatwoods. Portions of this area occesionally contain standing water for a day or so at a time during the period of the hard summer rains. The ground, hovever, soon bocomes dry, and the opon terrain afforde a habitat similar to a higher area. The other otations in which floridanus occurs cormonly are turkey oak, bluejack oak, and Leon scrubby flatwoods. Nosts wore found occasionslly to commonly in scrub, longleaf pine flatwoods, and xeric hrwnock; occusionally in Pomello scrubby flatwoods and mesic hamocks and rarely in Plumer olash pine flatwoods and hydric hamock.

Colonies wero found, for the wost part, in the surface stratum. Porhaps half as many nosts wero found in sand, but a majority of these wore associated with wood such the root system of living and dead setterbush in the P. sorotin-Desmothamnus association. One nost was taken from an Andropogon stem in the horbacoous stratum, and two colonies were collected from the arboreal stratum. 
L. pergandej floridanus was collected moct often from logs. In order of preference, othar places from which nosts heve been collected ares

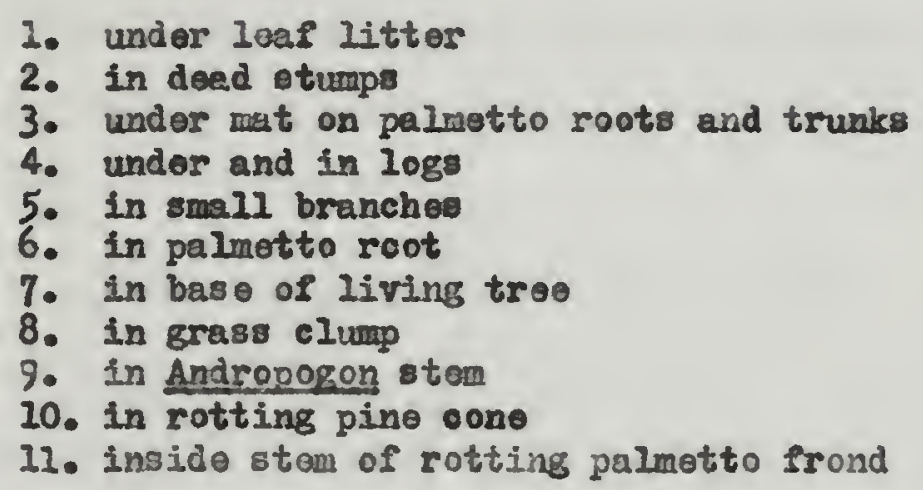

Nests in debris were comon, although somo containod a minimum of debris. or live colonios coliected from the surface stratum and counted, the number of workors varied from 21 to 58, and averagod 36. Anothor nest was taken from a small branch and contained 2 callows and 131 workers. Each of these nosts contained one queen. Still another nest was taken from a fallen log whioh contrined only 18 morkers and no queen; but perhape this pras only a section of the rhole colony. Eges, larvae, and pupse vore found in all months, although not in all nests. Winged form bogin to appoar in the nesto in lay and aro absent again by August.

Usually this ant can be seen in moderate abovo-ground activity in all months of the yoar. Its annorises and appearanoe in the Iiold are much like those of Phoidole dentato, and it is sametimes nocessary to examine closely a wandering individual before a determination can bo mado. 


\section{Leptothorex texconus darisi Thoeler}

The collection of this ant in Florida extends the known range considerably, sinee the subspecios was known previously only from New Jersey and Now Tork. Dr. M. R. Smith writes that the Florida pooimens do not differ from the pecimens collected in these northern localities.

L. texanus darisi was found occasionally in turkey oak and Loon scrubby flatwoods, and rarely in bluejack oak, black pine-fetterbush flatwoods, and xoric hamock. It thus shows a preference for the higher, drier areas.

Its nesting sites have all been in the subterranean stratum, either under litter or with litter or no crater in the open sand. One nest was discorered which had no apparent opening to the surface; the entire nest was within $1 / 4$ inch of the surface.

A nest collected in turkey oak contrined 18 workers and a queen, but no immature forms. No further information obtained concerning the lifo history of this ant.

It lo shy, and moves only moderately fast orer the sand whilo foraging. Like I. pergandel floridanus, it moves about in somewhat the same manner as the much more common ant Pheidole dentate. It has been taken foraging with Solonopsis geminate, and a lone queon of Cemponotus socius was taken with a davisi colony.

\section{Totramorium guineense (r.)}

This introduced species was found in four plant associations. However, only the aingle collection in turkey oak was taken from a atation. since the other collections were not made in tations, the relative abundance must bo besed olely on the few collecting trips made to the 
areas in question. Those throe remaining plant associations in which the ant was observed are similar to the descriptions of the respective stations given in a previous portion of this paper. They all had in comon their distribution alone the St. Johns River, a fret which soems to support the idea that the form is introduced. Irp 3 shows Burard's Roost in the southwert corner of the Reserve where the ant was taken raroly in river swamp and occasionally in hydric hamock. At hud Springs, nosr the swamp station, the ant was taken occasionally in marsh. There is a possibility that it had only recently boen introduced into turkey oak.

I. guinoenso mas represented in the surface and the herbeceous strata. Here the herbacoous strata is extendad to includo the flower ctalks of sawgrass. These vertical stalks, which bocomo hollow inside with a usual bore of $1 / 4$ to $3 / 8$ inch, cannot be considered true twigs because of the large dianeter of the bore, and because ants representative of twig-inhabiting form, such as spocies of Psoudomyrma, are not found here. One nest, taken from a flower stalk, was between two nodes of the - merass stem. Part of the segment was broken through, and thia had been replaced with black dobris, probably from rotting sawgrass blades.

In hydric hammock its nesting sites wore under the mat of a Sabel peimetto trunk, in the top of the atrophied root system, and in a sturap. In swamp, tho ant was found in a fallon log. The nost ramifiod into passageways, and occupied throe foot of the $10 \mathrm{~g}$ which had a diameter of two to two and one-half inches. A dealatod queen was taken while it was wandering in one of the buildings of the Reserve. One colony taken in marsh was found to contain 290 workers, 3 queans, eggs, 218 larvae, and 22 pupae. The arranganent of the castes 
in this colony, taken in a sawgrass flower ster, is of intoret. All of the nest wrs containad betwoen two nodos of the vcrtical atcm. An ostimated one-half of the colony urs in the upper half of the segment. Ierree, attached by their antcrior ends, were jutting out into the hollow of tho stom. At the top of tho section, clinging upside dow to the nodal mombrane, were many workers and a queen, along with many egss. Immature forms have been found in the nests fros July through November, but probably occur in all months of the ycar. Alate and doalated fomales have been taken in Auguet and September. No infermation has boen obtained for tho males.

\section{Strumizenys louisianae Roger}

S. Louigiana has boon found rarely in turkoy oak, bluejack oak, xeric hamook, mosic hamock, and river smamp. It is roro comon on the Reservo than most species of tho closely rolated Snithistrumg. As with inithistrums, tho most successful moans of collecting it has provon to be by use of a Berlese funnel. It has, however, beon taken from nosts in fallon swootgur (Liouidambar styraciflua) loge in which tho wood was fairly dry, and in a differential stato of decay. It was taken also from the moist wocd deprio inside a Nagnolio Erandifloro logo Berlese oollections were made between temperatures of $24^{\circ}-30^{\circ} \mathrm{C}$. and relative humidities of $50 \%$ to $95 \%$ As in the cese of smithistrumn on the Reserve, the relative humidity was always above $50 \%$ at the time of collection.

In the Gaineaville region all of the collections of this species were made in loge of Magnolie grandiflora well along in the process of decay. The frequent collections in magnolia ma indieate a 
preforence for the moist debris found in theso logs.

The ants of this grecies, like those of the species of Smithistruma, aro difficult to locato in the fiold. "Whoir color, which is like that of the wood in which they nest, and their habit of ranining very still in their nost after it is opened greatIy enhance the chances of overlooking a nest. Like Smithistruma also, thoy move with a slow, deIiborate gait.

\section{Smithistrume Brown}

In 1949, Brown erected the gonus Smithistruma to roceive most of the forms which had previously formed the subgenus Conhaloxses of Strumigenvs. Cophaloxys, however, has boen shown to be prooccupied, and Prichoscapa is the naxt available name for the group. Brown, horvever, recognizes that the typo spocies of Trichoscans, merbranifera, is distinct from the rest of the group. He has thereforo raised Ireichoscene to the rank of genus, and has introduced Srithistmma as a now genus. Croighton (1950), although he was undoubtedly aware of the revisionary measures undortaken for Stmonigonys, makes no noto of then. This dissertation Fill follow Grown's treatinent of the group.

Ants of the genus Smithistmene build noets only ono or two inches in diameter, sometimes deop in the wond. Careful scarching is usually nocessary in order to find thoir nests. The color of the ants, which is very much like that of the material in rhich they live, and tholr habit of remining very still when their nosts are broken open, make it necessary to look at a nest for several soconds before tho ants are seen. It will be noted that, although the temperatures varied videly at the time of collection, the reletive humidity was in all casos above 
50\%. In most cases too few collections wero mado to draw any conclusions concerning preferonce of stations.

\section{Smithistrums bunis Brown}

The ingle collection of bunkt wa mo from turkey oak. The collection was made by use of a Berlose funnel frora litter gathered on an overcast day whon the temperature $37^{\circ} \mathrm{C}$. and the humidity $66 \%$

\section{Smithistrume Irroatg (Roger)}

S. clypeats was taken occasionally in xeric haumock from Berlese samples. Two dealated femalos vere taken with workers in one aample. It is possible, therofore, that the nost was in the las litter, or on the soil under the littor. This collection was made at $18^{\circ} \mathrm{C}$. and $54 \%$ relative humidity.

\section{Smithistrums croightoni (M. R. Smith)}

S. croightonf has been found occasionally in xoric hammock and rarely in bayhead. All collections vere made by means of a Berlese funnel from litter takon at tomperaturos ranging from $21^{\circ}$ to $30^{\circ} \mathrm{C}$. and relative humidity ranging from 50\% to $80 \%$. The litter samplo from beyhoed yielded the following ants along with the Smithistrums: Solenopsic molesta, Brachrovmex dopilis, and Pheidolo dentigula.

\section{Smithistruma dietrichi (M. R. Smith)}

S. dietrichi wes taken occasionally in turkey oak and rerely in bluejack oak. In turkoy oak, ono collection mas mado of sereral individuals in a 108 of Quorcus laevis wich war in an advanced stage of wet 
rot decay. Other collections were made by moans of a Berlese funnel at temperatures betreon $30^{\circ}$ and $40^{\circ} \mathrm{C}$. and relativo humidity botweon $50 \%$ and $70 \%$

\section{Smithistruma ornate (llayr)}

Two colloctions of this ant were made, one from scrub and one from mosic hamock. The collections were mado at temperatures of $28^{\circ}$ and $33^{\circ} \mathrm{C}$, with humidity of $80 \%$ and $98 \%$. Although two collections probably do not indicate the habitat preforence of this ant, it can be noted that they were both made under more or less mesic conditions.

\section{Smithistruxa pulchello (Emery)}

This species was found rarely in both xeric hamock and river Ewamp. One collection was mado from a Berlese sample with a temperature of $14^{\circ} \mathrm{C}$. and $75 \%$ relative humidity on an overcast day. Specimens wero also taken from a mammal trap baited with oatmeal and peanut butter when the temperature was $25^{\circ} \mathrm{C}$. and the relative humidity was $87 \%$.

\section{Smithistrumg talpo (Wober)}

S. talpa was taken raroly in Pomello scrubby Platwoods, nesic hamock, hydric hammock, and bayhoad. In bayhead a nest was found in slash pine (Pinus elliotti) bark at the base of the living treo under litter and just below the soil surface. There was some debris in the nest, and the bark was moist. Other collections were mado from Berlese samples between temperatures of $19^{\circ}$ and $27^{\circ} \mathrm{C}$. and between $60 \%$ and $65 \%$ relative humidity. 


\section{Prachvavemex sevtontrionalis seminolo (Whoolor)}

This fungus-growing ant was found to profor the higher, drier aruas. It was taken comonly in turkoy oak and xeric hanasock; occasionally to commonly in bluejack oak; occasionally in scrub, foon scrubby flatwoods, and Pomello scrubby flatwoods; and rarcly in mosic hatanock.

Areas with littlo or no litter are preferred by sominole, although it has boen taken in sand bencath litter, and Colo, in tho oreat Smoky Mountains, found it bencath stonos. Characteristically the colonies build an incomplete crater around the nost oponinge. Some nests, howorer, wero found with complote crators, and others with no craters. Even in light litter the ants bililt craters, piling the sand pollets or the surrounding leaves; in heavy litter the craters became obseure.

Incomplete craters faced no coman direction. An average crater is 6 to 8 inchos in outside diameter, and about 2 inches at the highest point. Wosts Elways have only one opening. No rocords of the ant wors made other than in tho subterranean stratum.

A nest of this fort, collected in Docerber, 1949, contained 382 workors and I quoen. All of the workers, except a very few, were clustered about tho queen in a doep chamber 4 foet below tno surface. The passagemays went dorn to about 6 foet, but no immaturo forms were seen. The doeper, vertical pacsageways ( 3 to 6 feet) wero widencd at places for several inchos so that it would have boon possible to place a 2-dram vial within the gallery. Other nosts were oponod during the same wook, and in all of the nosts the majority of the individuals remined well below the surface; only a feu wore seen excevatins. The top gallories and chambers of most colonies were ampty. In the nesis which wero active, workars were bringing to the surface organic substances which might have boen usod 
fungus substratum. Some nest openings, and athor nost passageways were closed, and in three nests smell rod-shapod particles which resemblod in size the nettles of opuntio wore soen cloggine the nest oponings. Thase particles wore fragments of sodge or grass (probably Axistida stricta). Hixed with these, wore many more unidentified plant fragmonts. Only very pon svidence of fungus was visiblo.

Immature forms occur during all except the winter months. Wingod form have been collocted in April through July. At 5 Polf. on July 8, 1948, an overcast day, fomales wore soen coming from a nest in turkey oak. Both the attendant workers and the fomales were very exeited. At about 5 minute intervals tho fomales flev off from slightly raised objecte near the nest, thoy showed a epocial proforonce for a raisod twig near the nest opening. Erach foralo roso almost streight up into tho air in a rigzag fashion, until sho was out of sight abovo tho treetops.

\section{I. soptentrionsis seminolo znores only modoratoly fast whilo} foraging, but it is deliborato in its morements. It usually does not attempt to hide when disturbed, but bocomes immobilo, and depends on its rough intogument and tubercles to protect it. Foraging is almost complotely otopped during leto Decomber and January.

The ants characteristically carry leaves slung over thoir heads. Workers have also been observod taking seeds back to thoir nests. On several occasions they rere observed carrying away soeds which had been discarded from Pogonomvrmox bedius mounds; this activity alwaye took place at night when the Pogonomymex nest opening was closed. Hymonomycotos fungi growing in a lawn also attracted thom, and thoy carriod piocos of them back to their nests. 
Sulonopsis geminata which was under a log. Species of Corrodentia havo also boon picked up with collections of seminole.

\section{Subfamily Dolichodorina}

\section{Dolichoderus pustulatus Mayr}

D. pustulatus is one of the fer ants taken more than three times that occur in only one station. It was found occasionally to comenonly in marsh. Perhaps more collections around the margins of low, wet places, such as flatwoods ponds, will reveal ito existence there also. The spocies has been recorded northward to Now Jersey.

Collections were made most often in various aspocts of the herbaceous stratum, while others were made from shrubes

nest betweon septa of rotting Sasittario stcm savgrass flower stem twigs of buttonbush (Cephalanthus occidentalis)

Winged forms are present in the nest from September to Fobruery. Immature forms were found in the nests in all months.

The speed of movement of the workers is moderete to considerable and their size and behavior is somewhat like that of the subgenus Colobopsis of Camponotus, living in similar nesting sites in rah.

\section{Iridomyremex humilis Mayr}

This, the Argentine ant, has not been collected from the Reserve, but was collected from Palatka, 17 wiles to the north of the Reserve. Dr. Smith informs wo that the ant was found at Palatka obout 1932 when the Bureau of Entomology was soouting for the ant there. It has been 
reported from there at other tires since then, and was taken there by the author in July, 2948, and on February 17, 1950. It appears comnonly along the sidewalks of the town, and nests can be taken from under many stones. Probably it makes nests also under the oidewalks.

The we with which the dispersal of bumilis takes place is indicated by the numerous individuals in the following set of circumstances. A station wagon with a wooden body had been left in Palatka for several days in the same spot. When the automobile weo driven beck to the Reserve, it was noticed that many anto had piled sand between the door and the door casing, and had establiahod themselves there, as well as in other places in the station wagon. In all likelihood, the adoptiveness of this ant allows it to move in this way into ships, trains, and other moans of transportation, and thus extend its distribution.

\section{Iridomrrmex pruinosus (Roger)}

Eight stations were ocoupled by this ant. I. pruinosus occurrod comonly in turkey oak, Leon scrubby flatwoods, Longleef pine flatwoods, and black pino-fetterbush Platwoods; comonly to oceasionally in xeric harock; and occasionally in bluojack oak, scrub, and Ponello scrubby Platwoods. It secms to prefor areas where its nests are almost never in shadow, whether in the high turkey oak or low black pino-fetterbush flatwoods. The highest numbers of nests occur in stations where there are open aroes almost or entirely devoid of litter.

This ant ean be found most often in the subterranean stratum, but also in the surface stratum. Most of its nests in sand are either rudimentary or incomplete craters, but there are instances when the nests are found with no crater or with complete craters. Some of these nests 
oocur under litter, while others are built around the beses and root systens of shrubs. It occurs about equally often under the bark of fallen logs and dead stums, and io also found in litter. The nests undor bark are most often built in the debris which occurs between the bark and the rest of the wood the immature forms, as well as workers, are found in this dobris. Several nosts were constructed both in logs and in sand.

Ienature forss can be found in the neste in all months. Winged form have been taken in Way through July.

When the ants become active in the summer and fall months, or in the other seasons of the year, they form characteristic trails across the sand, extending them sometimes into the vegetation. Fach individual is energetically keoping up with the ant ahead, making a more or less straight and longthy column. Such trails are exemplified by an instance in bluejack oak. Two columns, at an angle of $180^{\circ}$ to each other, originated from the same nest. Both columns seamed to have worn a path through the litter. One columan was followed for six yards, where it eplit, sending ono branch at least twenty foet up into a bluojack oak, and the other up into anothor bluejack oak. The other column was followed into litter where it dispersed. When the ants are moving very fast under the influence of the sun, they follow a zigzag pattern, epecially on vertical surfaces.

Some of the nests in wood have been associated with termites. The eignificance of the association is unknown. 


\section{Dorymyrmex pyramicus Llaropectus Y. R. Smith}

The confusion which has resulted from recognizing color variants in Derymuremex hes boen disoussed under the section dealing with the subspecies pyramicus. Since two subspocies of the same species have boen found in the samo area and in identical nesting situations, it is probablo that this rogion is an area of intergradation. In fact, sperimens hare boen found which appear on morphological grounds to bo intergrades betwoon prramious and flavopoctus. More exact identifioation of intergrades cannot be ande until types of both pyramieus and elavopectus are seon. Although no epecimeno of this form have beon found on the Reserve, nests have boen collected in Salt Springs, Uarion County, acroes the St. Johns River from the Reservo, and in the town of Wolaka. A typical nest was taken in an orange grovo from a crater 4 inches in diameter; $1 / 4$ to $1 / 2$ inch in hoight; and with one opening $1 / 8$ to $1 / 4$ inch in diameter.

\section{Dorymurmex puremicus (Roger)}

The material listed under this heading was determined D. erramicus var. Elarus by Dr. U. R. Smith. Croighton (1950:346), however, in dealing with tho species pyremicus, has discardod oolor as a soparatory character, and has found certain structural charactoristics, such as the shape of the mesonotum, to be clear-cut and constant. Becauso color was proved to be inconstant, ho hes synonymized all color varieties.

However, all of the spocimens that have the color which is supposedly characteristic of flavus cannot bo grouped together on morphological grounds. Some of them are the lighter color phase of prramicus, while others are Smith's elaropectus. In determinations for the author, Smith, stressing color, ovidently recognized a different aggrogate of 
spocimens as his subspocies plavopectus than Creighton rocognizes as flaropectus in his 1950 peper. This disertation will follow Creighton by using structural differonces as separatory characters.

These ants prefor opon sand, and nosts havo beon taken occasionally to comonly in turkey oak and xeric homock, and rarely in bluefack ak. The great majority of neste were complote eraters in open areas. Colonie were also found in a fow rudimentery craters, ono nest under a log, and another craterlese nest with a loaf over the oponing. Complete craters of these ante vary from 2 1/2 to 4 inches in diameter; from $1 / 4$ to $3 / 4$ inch in height; and always have ono oponing to each nost. Winged forms of this group hare beon seen May through August. A flight was observed on July 28, 2949.

Ants of this group are very agile and are ablo to climb vegetation. Their foraging sometimes extende into the night. One colony was found in association with a queen of Camponotus socius, taken with the nest only 4 inches below the ground surface.

\section{Tapinoma sessile (Say)}

The distribution of $\mathrm{g}$. sessile indicates that it is influenced by man. Although in othor parts of the country it is widespread, on the Reservo it was takon in only ono plant association. This ono collection was de in marsh along the St. Johns River, where it is possible that it bocame established after boing transported by man. In this connection, I. sessile was recorded from Ploating iolands in the Gainesville region. Several males and fomales were attracted to light in the buildings on the Resorvo. Females wero taken in March and July, and Apriles in April. Colo (1940.64) gires a good account of the nesting habits of 
I. sessile in the Great Swolky Wountains: "It was confined for the most part to rather open situations, although nosts havo boon observed in dons woist woods. The ants nost in the soil beneath stones, logs, stumps and strips of bark. The nests aro shallow affairs extending no more than an inch or two beneath the soil surfaco. Lost of those in the Park wore under rather lerge flat stones loosely appressed to the soil. Boneath such a cover the orango colored brnod was confingd to pockots in the soil, or to superficial chambers made by the workers, or vory erequently scattered along one inner margin of the stone and mingled with detritus. The colonios vero yenorally populous."

\section{Subfamily Formic1nao}

\section{Brachyevrmex depilis Proory}

In its distribution in plant associations, B. depilie ohows a preference for all types of flatwoods, although its occurrence was high in othor associations. It occurs most often in longleaf pino platwoods, Plumer slash pine Platwoods, and black pine-fetterbush flatwoods, where nests vere rocorded cormonly. B. depilis was found occasionally in turkey oak, bluejack oak, scrub, Leon scrubby Platwoods, Pomello scrubby Platwoods, Rutlego slash pino flatwoode, mesic harmock, hydric hamock, and bayhead. There seems to be no reas on why it should not aleo bo found in xeric hammock and river swamp.

Lost of the nesting sites of $\underline{B}$. depilis wore in the surface stratum. Those neste in sand were associated with wood. Many nests, rocorded from logs were taken partly from sand although their major portions 
were in buried wood. Other nests associated with sand were in tho roots of shrubs or other plants. It is probable that theso ants were attonding aphids.

The most important nesting sites for B. dopilis on the Reserve are In the bases of living treos and in fallen logs. Other nesting sites in order of preference are:

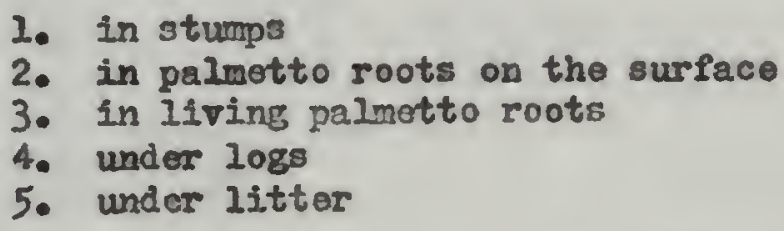

They have also boen found in sand among the roots of livins shrubs, and in sand among forn roots. Nests can be found in wood in a variety of atages of docay, but thoy occur mostly in or noar hard wood. B. depilis was taken comonly from burned or charred wood. In most casos the wood was wet or moist.

Many of the nests of B. depilis, especially thoso in the bases of living troes, are in scctions as explained under Cramatogaster minutissimg missouriensis. Thoy contain about the samo numbor of Individuals as do nests of the latter ant. Inatures of B. depilis can bo found in 211 months. Winged form havo been rocorded from Vay to JuIy.

Holasses traps attract this usually slow uoving ant. As mentionod above, it attonds aphids. It has boen found nesting in closo proximity to Ponera trigona opacior. 


\section{Camponotus castaneus (Latroille)}

This spocies has been taken in oloven stations, but never with more than occasional relative abundance. It may yet be found in one or two more plant associations, but it is unlikoly that it will occur in marsh. C. castaneus shows a proferonce for movic and hydric conditions. It has been taken occasionally in scrub, Leon scrubby Platwoods, Pomello scrubby flatwoods, Rutlego slash pine flatwoods, xeric hamock, mesic hamock, river swamp, and bayhead; and raroly in longleaf pino and Plummor slash pine flatwoods, and in hydric hamock. In xeric associations, its nests are only in the more moist eituations. Thero is reason to suppose that further collecting will show a higher relative abundance in hydris hamock.

Nests of $\mathrm{C}$. castaneus havo in all cases been in the surface stratun, in logs or dead stumps. It profers tho last, noist stages of decay, and has boen found only in $10 \mathrm{gs}$ of broadleaved trees. Nests vill probably also be found partly in tho soll, associated with a log or other cover.

The largest colony counted contained only 22 workers and a queen, along with oggs and larva. This nest was in all likolihood young; othor nests have been seon which woro estimatod to contain botweon 100 and 200 individuals. Fomales have boen obsorved in the nost in Fobruary and liarch, and males in Fobruary through May. A mating Ilight was observed on Narch 22. Females have boen caught on the ving in Fobruary also, and males have been caught at light traps in Harch through Hay. Imature forms occur in 2.11 months.

C. castanous is an energotic rorager. When the tomporature drops and the relative humidity rises, it increases its spood of movemont, 
indicating its nocturnal tondencies. It ofton forages in open areas, such as firelanos, noar the mosic or hydric site of its nost. It is one of the ants which temporarily ceases activity during vinter monthe.

Observations on five workers and a number of cocoons of both worker and reproductive castes, brought into the laboratory from a volldecayed log in bayhead, hare yielded miscellaneoue date ooncerning the habits of the ants. The ant3 were kopt in a glase and plaster of Paris nest, and for the first month no food was giren thom. When the cocoons were placed in the nest they were mixed with debris from the origimal nest in the fleld. Within a few hours, however, the cocoone had boen moved from the debris into the opon at one side of the nest, indicating no desire to aroid light. On the second day the cocoons were more dissominated; some were placed by the workers near the sponge; ome wore under debria; but most were still in the original pile.

On the third day callows bogan to amerge. In the cases of the sevoral watched, an attendant worker broke opon each cocoon, pulling little by little at the cocoon, at the sane time dragging the pupa over debris and around the nest. In several cases there were more than one worker attending a cocoon at one time. In the process of removing the insect from the cocoon, the cuticle fitting tightly to the pupe was eaten away by the nurse. The procodure took an hour or more. When the callows first emged, they wore very uncoordinated, and remined bunched together in one portion of the nest.

what were evidently acts of regurgitation were carried on between the nerly arrived callow and the workers. In this operation the heads were sot at an angle so that one mandiblo of each ant could be placod on the elypeus of the other, while the other mandible was placed under 
the bead of the other ent. Ono antonna of osch ant intormittently atrokod the elypeus of her partner, and the other stroked the under side of the hoad. Pairs of ants remaned in this pose for extended timos. Four days after their emergonce, the callows assumed the coloration of the other workors.

One reek after the ants had been brought into the nest, several. callows, partially emerged, had been eaten. All of tho discardod cocoons, as woll as tho partially osten callows vore pilod near the spongo.

Whon food was introduced a month after the workers and inmatures were inst put into the nest, the workers undertool to foed a winged femalo callow. This fercalo was much less violent in recelving her food than was a queen of Camponotus sbdominalis Sloridnnus. The femalo used her antenna only slowly and inconsistently, and while she did make use of hor forelegs, they were more for support on the worker. In distinction, the ferale of C. abdominalis ploridanus otroked the worker partner hurriedly, especially with hor forelegs. The heads of the castanous female and worker were in much the same position as that described abore for vorker and callow. The female would, howover, at times invert her head under tho had of the worker.

\section{Camponotus gocLus Roger}

In 1932 Whooler describod Camponotus sociue var. osceole from Florida. He soparatod it from socius by reas on of throe yellow otripes on the gaster as couparod with two in socius. During the presont vork, It has been found that individuals from tho sane nest appear with the third yellow bend eithor almost or quite indistinguishable or olso otrongly evident. Creighton (1950) is therefore followed in synonyraizing 
G. socius var. oscoola with c. sociug.

This ant prefers the high, dry areas to the exclusion of the wetter environments. It was taken comonly in turkey oak and xeric hamock; and occasionally in Loon scrubby flatwoods and bluejack aak. Like Aphronozaster ashmeadi, socius can be found almost always in situations where the litter is relatively light.

All noots of socius woro taken in the subterranean stratum. A majority of them were in the open where there wes no litter. None of the colonies maintained a recognizable crater, although around some nest openings there were rings of sand pollets in what were the beginnings of craters. Nest openings are often found at the bases of turkey oak (Quercus 2aeris); these noste go down into the root oystems of the oaks where the rootlets may offer support to the nest chambers and honeyder from associgted aphids.

In turkoy oak and xoric harmock, socius is, on hot sumer days, the most conspicuous ant on account of its constant and excited aboveground ectivity. Itg large size and quick movement, along with its habit of moring on top of the litter, make it much more conspicuous than a rolatively reclusive ant such as Odontomachus hatoda insularis. During the winter monthe, oren though both day and night remined warm, and often became very hot, the abore-ground activity of the ant ceased almost entirely.

The feeding activitios of the ant are varied. Spocimens were taken in November, 1946, by Ur. J. C. Moore from a fox squirrel nest, 26 feet above the ground in a turkey oak tree, where the ants were probably feoding on other arthropods. The species is always attracted to molasses traps in farorable plant associations.

A queen of $\mathrm{G}$. sociug was taken into the laboratory and placed 
in on artificial nest on October 19, 1949. She was given nothing but water. During the time she spont in the nest she repeatedly laid eggs, but none of them developed beyond small Larvae. On February 2, 1950, two Camponotus abdominalis floridianus larvae rere placed in the nest, and were accepted by the queon. On the next day, a pupa and larva of Aphrenogaster acrospina were put in the nest, and although the queen did not accept these, she did not appen to reject them. However, on the following day, the introduced pupa was destroyed or exten. The larvae wero cared for until March 15, whon they also disappeared. On June 30, after $81 / 2$ months without lood other than the sustenance the larva and pupa may have provided, the queen died.

Leptothorex teranus davisi was found associated with this spocios on October 19, 1949, in turkey oak. A nest of the Leptothorex, including a queen, wes taken along with a lone queen of Camponotus. No crater or nest opening to the sand nest was visible. C. socius has elso been reported as a casurl in the burrows of the Florida pocket gopher (Geomre floridanus) (Hubboll and Gorf, 1939).

\section{Camponotur nearcticus Bnery}

It is not entirely cleer from the work of the present study whether or not Whooler's G. carroo rasilis pavidus ought to be sgnonymized with nearcticus. The two variants have beon quite distinguishable on the basis of their color, and have occurred in entirely different stations, tho black variant nesting in open situations, the lighter variant, paridus, nesting in the shaded mesic or hydric situations.

The probloin as to what the relation of the two variants is, would then present itself. It would perhaps bo possible for peridus and 
negrcticus to bo ocological subspocies, or along the same line, it would be possible for the two variants to havo undergono ocological isolation and already be species. However, ecological subspectes and speciation are not well foundod in formicid systemtics.

In addition, Croighton (1950:388) brings out the point that thero exist soveral namod varioties of carvae [fallex] which aro basod on slight color differencos. "Foch is admittodly trensitional in this respect. In oach the definitive color characterigtic was known to vary in the type series." If this bo true, there soem littlo reason for rocognizing paridus and negrcticus as separato form on tho basis of color distinctions. In this dissortation paridns is synonymized with nearcticus.

C. nearcticus was taken occasionally in turkey oak, bluojack oak, Pomello scrubby flatwoods, longleaf pino flatwoods, mesic hamock, and river swamp; and rarely in scrub and bayhead. It malso be found in other stations where the trees provide branches as arboreal nosting sites.

Nests in the arboreal otratum are characteristic, but on one occasion a nest was taken in an oak $\log$ which had boon caught in an aak branch and was supported by the ground at an $80^{\circ}$ angle. The black varlants of nearcticus prefer small branches of pine in open areas, although some wero taken in twigs; tho wood was usually in the first stages of decay. The lighter variant, on the other hand, was found nesting in small branches of hardwood troes, generally in shadod mesic and hydric areas. It is possible that in the more intense light of open areas the ants take on a darker appearance than in the more shaded hamock areas.

The number of workers in 4 nests of nearcticus raried from 28 to 91, averaging about 69 workers per nost. Another, probably incipiont 
nest, contained 12 workers. In only this last was the quoon taken. Imature forms have boen observod in the nests in both sumer and winter. Winged forms have been found in the nests and on the wing from lerch through July.

G. nearcticus is not a conspicuous forager, but it can at times be seen climbing hurriedly on the trunke of pines or oaks. Morkers were discovered by Lr. J. C. Hoore in a fox squirral nest 45 feet above the ground in turkey oak stand. Mr. Moore statos (in litt.), "Cortain beetles, lopidopters, and stratiomyid fly larva were much more abundant than the ants in the wet, rotting interior, $90 \%$ of which was Spanish moss." The workers in this case wore probably foraging for food in the squirrol nest.

The ant has a tendeney to bocome active on cloudy days. Foraging continues into the night, and workers have beon attracted to light traps. The spider, Furopsis funebria Hentz (det. W. J. Gertsch), of the family Theridiidee, was taken in a nest of noarcticus.

\section{Camponotus, oubgenus Colobopsis Layr}

llost of the Colobopsis on the Reservo seem to be more closely allied to oither pylartes Wheeler or to impressus Roger than to any others of the known species from the United States. As Whoeler (1904:149) admits, pylartes is very close morphologically to impressus Roger. Whoeler distinguishes the two forms of Colobopsis on the basis of the shape of the thorax in the soldier and worker, and in the coloration of the gaster which is banded besally with yollow in prlartes. Comparisons of soldiors and workers from the same nest with the descriptions of impressus and pylartes given by Wheoler (1904:144 and 147) ohow that individuals from 
the same nest seam to vary between the two species in regard to the conformations of the thorax and the coloration of the gaster. The intranest variation is such that the Colobopeis found on the Reserve could not bo umaistakingly identified; they are treated under one hoading.

A third form which shows variation in a difforent manner was found on the Reserve, but because only a fer specimens vere taken, it is not included here. Although this third form has a resemblance to the other Colobopsis, the for worker or soldier measures only 3.1 m. In totel body length, in comparison to $4.3-4.6$. for impresens and 4.5 5.0 m. for prlartes (Wheoler, 10c. cit.).

Ants of the abgonus Colobopsig on the Reserve prefer mesic and hydric situations in which thore are vines or other ouitable broadleaved twig vegetation. Ants closely resembling priartes occur comonly to abundantly in marsh occasionally to oomonly in mesic hamocks occasionally in acrub, Pomello sorubby Ilatwoods, xeric hamock, hydric bamock, river swamp, and bayhoad; and rarely in Plumer slash pine flatwoods and Rutlego slash pine flatwoods. Nesto were arboreal in a great jority of cases, but two nests were found in samgrass flower stalks, and several were in planted bamboo stalks. Nests wore found in greatest abundance in twigs, much less often in galls, and only once in a mall branch. Nesting sites of all Colobopsis on the Resorve are similar.

These ants, as well as ome Crematogaster and Solenopsis, subgonus Diplorhoptrum, nest in "gections", defined under C. minutissimg missouriensis. A good axample of this typo of nesting was observed in a planted patch of bamboo. Although the several nodes in the middle of the stalk had been permeeted by the ants, many of the other nodes which the nest included were intact, and the nest was thus split into oeotions. 
A count of 10 nests revealo a range in number of workers from 15 to 269 ; in soldiers from 1 to 72 ; in totels of workers plus soldiers from 16 to 341. The average of the total numbers of workers and soldiers was about 103. Queons wore abeent from all but one of the nosts counted. Fomalo pupa were obsorvod in the nests in April through June, and adult females were taken over the same period. Halos were found in the nests in April and liay, and again in Noverabor. Immatures occur in all months, except during cold spells. All forms of Colobopsis on the Reserve seem to follow this general outline of life history.

Whon this agile ant akes a nest of a bamboo stalk, as explained above, it cuts a circular nest oponing through the internodes of the stalk B onewhere near the conter. The planted bamboo thickets are a favorite haunt of the downy woodpecker (Dendrocopus pubescens). In sooking ants these birds made a characteristic hole in tho bamboo stalk. Each holo was about $1 / 4$ inch in vertical length and $1 / 8$ inch in wiath. Wost of the woodpecker holes wore near the nodes, in contradistinction to the position of the ant-ade holes. Two theories for the position of these holos were advanced by Mr. W. M. MeLano who observed the actions of a bird eating the ants from a stalks 1) the bird y find more support in gripping the node; and 2) the stalk nearer the node will bo more resistant to bending and will be more easily broken through. If the last is the sole reason for the position of the holes, it would show a great deal of keonness on the part of tho bird in selecting a spot to peck. An interesting record was of an ant which more closely resembled impressus than prlartes. All pupa observed in prlartes nests wore naked. But pupeo taken from the former neste were in cocoons. One cocoon contained fire individuals. 


\section{Camponotus abdominalis floridanus (Buckley)}

c. obdominalis Lloridanus profers the better drained areas of the Reserve, especially turkey oak and xeric hamock, as well a black pine-fotterbush llatwoods, but it is one of the three ants which have been found in all plant associations studiod. Nests occur comonly in all atations excopt Pomello scrubby flatwoods, Rutlege olash pine Platwoods, river stramp, bayhead, and marsh in which thoy appear occusionally. This eren distribution in tations is matchod by its occurrence in all strata and in a large number of nesting sites.

Within the strata the ant shows a definite preforence for the surface stratum, although it has boen found over a third as many times in sand, in a jority of cases under some sort of cover. Ralatively fow records wore made of nosts in grass, treos, and shrubs.

The most strongly preforred nesting sites are in logs and stumps. Well preferred also are situations under logs, and under litter. Nests are found often:

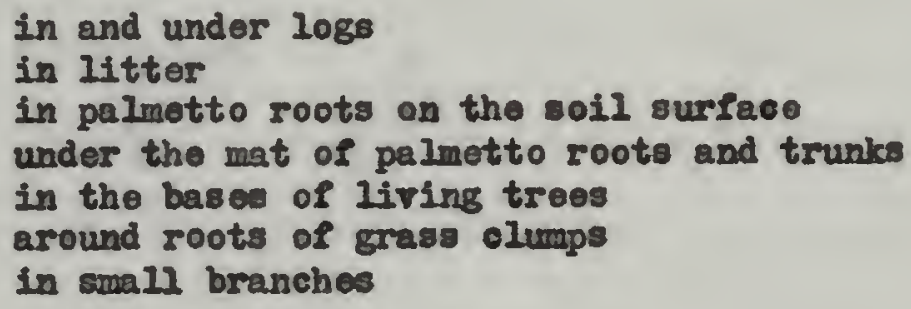

Other nests have been recordeds

from open sand with rudimentary or no crater from between sawgrass blades from sawgress flower stalk in the wall of a building bohind comont under a dead frond resting against a cabbege palm throe foot above the ground surface in the stub of a live oak limb ten foot above the ground

The typos of wood in which C. abdominalis Ploridanus nosts vary considerably. Records have been made from logs and stumps of pine and 
broadleared trees, with or without bark, and either charred or unburned. The wood ranges, moreover, fros the first stage of decay to the later stages, although the latter seas to be preferred. In way cases the wood is moist, but nests occur in dry as well as vot wood. Uost colonies permeate a wholo section of $\log$ or stump and occupy both the area under the bark as woll as most of the wood itself, but nosts have been found solely in one position or the other. Records show that the ant is characteristically taken from ohambers in the wood, especially in stump, where a part of the nest will occupy the root system, and another part, chambers in the sand; many colonies extend to higher lovols in the wood. Likovise, nests recorded from sand are usually taken from chambers in the sand, a majority of which, howerer, are associated with roots or rood sunken into the soil, and most do not soem to have boen built by the ant. Ur. J. C. Yoore took spocimens of this ant on several occasions from fox squirrol (Seiurug niger niger) noste in turkey oak. Ho indicates that in at least ono nest, 21 leot high in a turkoy oak, the ants wero evidently pormanently occupying the chamber of a squirrel nest made of twigs and leaves. As he broke open the nost, the ants wero seon to piek up their imatures and carry them to safety.

A typical nest of this ent, countod in Fobruary, contained 726 vorkers, as woll as inenatures. Inenares secm to be present in all months, although an absence of 8 ome forms socms to relloct cold wathor. Flights of males have been observed in June through August, and in larch. Flights of feanlos wero recordod for Juno through August, and in llay. Reproductive caste pupae vore observed in the nests in Oetober. Nesto with a lono queon have boon found as early as Fobruary. A group of females vero observed in the process of making 
a flight at 7:40 P.15., during dusk, on JuIy 13, 1948. No males were obeerved. The sky was orercast, the temperature was $27^{\circ} \mathrm{C}$. and the rolative humfity was $88 \%$. When observed there wero perhaps fifty forales to be seen, but the flight had probably been going on for some time. They chose the highest possible places to start their independent Plights, crawling onto a tin can on the steps of the building in which the nest was locatod. Erach fomale mado a very short preliminary spreading of wings before the flight. A fev attenpted flight, but fell over backwards, only to make a second successful attempt. Within a space of ten minutice or so, most of the fenalee had left the stope in flight. They took to the air at a rate of from throe a minute to ten or twelve a minute. Each ant ascended at approximately a forty-five degreo ansle to the ground. Kost flights proooeded in the direction in which the ent was headed at the taking-off point, but some averrod in one direction or enother, perhaps being caught in a wind current; they alvays, however, mintainod somewhat the same angle to the ground. When the last of the queen had left it was dark. During the whole ceremony, many axcited workers wero In attendance.

On June 29, 2948, an aggregation of les abore ground was first noticed because of the excitement of workers traveling in filo some distance from the nest. These worker wero followed to the nest in a stump in turkey oak whore the males vere wandering about the nest site with workers in constant, excitod attendanoe. The rees soemed to wander farther from the nest than tho workers would pormit, for tho latter were constantly carrying winged fors back toward the nest oponing. Most workers carried the los by grasping then by the hoad, with their body straight out in front of the worker. Although the nest was watched until 
It became impossible to 800 the ants, no flight was observed. The temperature at the time of observation $25^{\circ} \mathrm{C}$, and the relatire humidity was $40 \%$.

On July 3 a dealated femalo of G. abdominalis Ploridanus was brought into the laboratory in the trig in which sho was found. When placed in a container, the twig was open at both onds, but the queen soon shut off the ands with fragments of wood. During her confinement only water was given her.

On the 12th the twig was remored from the container, and the queen was separated from a clutch of oggs first noted that day. During oeveral frantic searchinge of the container, she explored under the remaining slivers of wood with hor antennee. Sovoral times she paused a fer seconde in her search, and bent her abdomen under hor loge so that it was facing forward, and oxaminod it with her antonnae and mouthparts. Botween her sorties, she remined at the top of the jar in the shador of the 1id.

The morning of the 13th found the queon characteristically posed over the ten or twolve egge which appoared in an unsymetrical sphere. The queen stood with her head slightly in front of the clutch which rested on the nest Ploor, 8 oumingly with her palpi on thew. From time to time she rould rub her antennae over the ogge and then along her forelogs. She was very excitable when disturbed.

On the 14th the remaining fragments of pood had boen placed on the songe. The egge had increased in number. When disturbed, the queen picked them up in her mandibles and posed with them, or carriod them to some other portion of the jar. The oggs wero always kept in a cleared portion of the jar. After moving the eggs, the queen repeated her actions 
of moving her antennas over the eggs and then under her forelegs. She consistently aroided the sponge.

It was difficult to tell exactly the length of time immatures required to develop from one stage to the next. There was eridence that at least some larvae and pupae had died or been killed, and new egge were boing laid constantly. Approximate times, under the conditions imposod for the dovelopment, were as follows: egg to larva, 21 days; larva to pupa, 20 days; and pupa to vorker adult, 8 days. It became apparant after observing another ant queen under conditions of low temperature that the length of the devolopmental period for any of the immature forms is lengthened by adverse conditions. It can be noted here that pupee of another queen, placed under identical onvironmental circumstances except for the abeence of adult forms, did not hatch.

The first offepring of the former queen were all very omall workers. These messured only 5.5 m. in total body length. No insects this mall were observed in large, thriving colonies in the field.

The fooding habits of the quoon of $\mathrm{c}$. abdominalis sloridanus are compared with those of $\bar{C}$. castanous winged fomalo under the latter ant. The amall workers montioned above took water from the sponge and went to the queen. Whon she oncouraged a worker with her antennae, the two ants would assume positions in which the axes of their heads were at right anglis, ono mandible of each above, and one below the partner's head. The queen stroked violently with her antennae during the regurgitation, and made frequent use of her forelege. The worker roturned the antennal strokes much more olowly, and made no use of the forelogs.

On several occasions, best exemplified in roots of saw palmetto, the immature forme of $\mathrm{C}$. abdominalis ploridanue have been found at different 
lovels in the neste. In all cases the pupae wore at the top, with the eggs and larvae together below, or the larvae pleced between the pupae and the eggs.

Most of the yoar this is a fast moving, excitable ant which finds no difficulty in negotiating the trunks of troes and the stems of herbs. Howevor, in November, espocially in 1948, there was a noticoablo coseation in its above-ground activity. During most of the year, it is active both in the day and at night, except during rain, when it and most of the other ants seok cover.

The foeding habite of G. abdominalis ploridanus aro rather diversified. It is attracted to liver well as molasses. On sereral occasions it has been recorded taking insects to its nest. Workers have boen observed actively dissecting insects before carrying them to their nest. Termites, colonizing in manstances the same type of wood as C. abdominglis Ploridonus, perhaps supply food for the ant. Whan a log which contains both termites and this carpenter ant is broken open, the excited worker ants pick up termites between their mandibles and carry thece as if they were thoir orn inmetures. This habit has boen noted in other ant forms.

G. abdominglis Ploridanus has boen found associated with the Pollowing animals:

Odontomachus hagnatoda insularis

Paratrochine parrula Urmecoph17a ? (Orthoptera)

termites (Is optere)

sereral beotlew and beetle larvee (Coleoptera) chilopods

Hiscoespis ? (Acarina)

In this connection it right also be montionod that on sereral occesions, dead workers of this ant were found tightly clinging to vertical grass 
stems, or to strands of hanging Spanish moss. The hoad of oxch vorker was upward, and from the head or the anterior portion of the thorax a fungus, tentatirely determined as Gordrceps sp., was protruding. The worker, being attacked by the fungus, and olimbing to die above the ground suggests an excellont medium for the diepersal of the spores of the fungus.

Whon logs which containod this pugnacious Camponotus and Odontomachus hrematods insularis wero broken opon, the workers of both spocies usually becane excited and attacked onch other. In the fleld, the Camponotus ware much suporfor in battlo, killing the odontomechus ach time an observed combat took place. In the laboratory, ants of this Gamponotus introducod into a common container with odontomachus lost as many battles as they won. The sting of the odontomgchus soenod to be fatal, but they were 1083 pugnacious than the carpenter ant, using thoir wandiblos to spring away from their adversaries. The Camponotus, quicker in the attack, were adept at sovoring logs and gasters from tho bodies of their opponents.

\section{Paratrechine 1onpicornis (Latr.)}

The nosting place of P. Longicornis are very closely associated with the etructures mado by man, especially in places where trade through seaports is conducted. Its distribution shows that it is a cosmopolitan speciee.

It was taken in Gainesville, and in Crescent C1ty, 11 miles to the southeast of the Velaka Reservo. In both of these places nests were found in crevices in the coment of walls of buildings, or beneath the coment in the soil at the base of the buildings. Unlike the imported Iridomsrmex humilis, nests wore always found in buildings, rather than, 
as in the case of I. humilis, outside the buildings in the ruderal sections. Although it nos not found in wolaka, it probably securs there In some soctions.

The long, spidery logs of this ant, and the fast, seozingly aimless moverants, are the besis for its boing terred tho "crazy ant" in some regions. It has beon observed to carry spidors to its nest, and to be attracted to candy, and sweets of other kinds.

\section{Paratreching arenivasa (Whoolor)}

Croighton (1950,408) lists aronivaga as a subspecies of melanderi. All the malo spocimens in his collection teisen in the typo locality of arenivaga have had gonitalia moro like Whoelor's Pigure of molandori than Iike his IIgure of arenivaga (2905). Moroover, he states that "I believe that I have fairly conclusive ovidence, from apocimons taken in southern Alabema, to show that melandori and arenivasa intergrado in that area." On this besis he has ardo arenivags a subspocies of molanderz.

Specinons collocted during tho present study, howevor, have had genitalia which agroo with cotype material of arenivage from the lus oum of Comparative Zoology. The gonitalia of those are very similar to the genitalia of arenivaga as plctured by Whooler. Thorefore, until it can be certain that Croighton collected arenivaga, and not another form, in the type locality of arenivega, and until the intergradation botwoen melanderi and arenivaga can bo ostablishod without doubt, it seoms best to use arenivaga as a distinct spocios.

Although Paratreohing parvula becomes vory light in color in the higher and more open areas of the Resorvo, it can almost always be distinguished from the deep yollow $\mathrm{P}$. aronivega. P. arenivaga is slightly 
larger than partula in most measurements of the workers, and is definitely larger in the vingod forms. Two of the best charecters for the separation of these two specios are the renation of the wings in both the male and Pemale, and the shape of the male genitalia. In the females the renational difforence is most striking. Here tho crossvein m-cu in parvulg is less than half the length of the same vein in arenirege. The crossrein m-cu In parvila is one-half the length of Rsfl, wile in arenivage both the crossvein and the lomgitudinal vein are approximately the same length. In ereniraga the processes of the median gonital valve are both long and - lender, whereas in parrula only the inner process of this velve is lengthoned, and the outer process is curved.

Ivon though erenivege io abundant hore, it was not listed by those who havo made state 2istr. Whecler (1905) remarks that it occurs in Now Jors oy and near Austir, Texas. Buren (1943) noter that the ant has been taken from the Missouri River bluff, but from no other part of Iowe. Tuis spotty distribution and its occurrence near ports and rivers man indicate that the distribution of the species is affocted by comerce. In all instances it builds craters similar to those on the Reserve. On the Reserve 2. arentrage was found in 7 plant associations. It nested abundantly in the high and open arees of turkey oak and xaric hamnock, where it sable to find suitable areas for its crater nests. Nest wero found occasionally in Leon scrubby flatwoods, and rarely in bluejack aak, Pomello scrubby flatroods, longleal pine flatwoods, and Plumer slash pine rlatwoods. Colonies were also found often in firelanes and on lawns.

Without excoption it was found in the subterranean stratum whero it built complete craters. These craters ranged from 1 to 3 inches in diameter and from $1 / 8$ to $2 / 2$ inch in height of the crater. All nests had 
one central opening. Wost of the nosts woro built in light colorod sand which matohed the light color of the ant.

Tho Imature Lorms probably occur in the nosts all year. Wingod Sorras appear in January and remain until February or March when the mating Plights take place. Activity that semed to be preparatory to one such flight was observed on Fobruary 12, 1950, at 4. P.ll., Just after a rain when the temporature was $21^{\circ} \mathrm{C}$. and the reletive huridity was $100 \%$ Although thore were many les in the uppor chambers of the nests, none were noted taking off from eight neste observed. There was an indication that the nests are sex specific, or noerly so, since all or a large majority of the winged forms in a nest were of one sex. Many of the workers were in a roplote Etate.

This is a modoratoly fast moving ant, but on warm, overcast deys it tends to increase its speed of movenont. It is active during both the day and night. During the rinter months its above-ground activity becomes limited.

Uany animals hare beon found in association with this ant. In the neste montioned above from which the winged forns were onerging, a black cricket with red markings on its hoad was obeerved, but not taken. P. arenivage has been found on quite a fow oocasions with the following:

Solenopsis molesta Solenopsie pergandei Roticulitermes spp. (Isoptera)

The termites were always in smell pieces of wood buried in the sand, and the arenivega nests passed through or olose by the wood. The Solenopsin occupied chambers of the Paratreching nest about ono-half to one foot below the surface. On occasion both Solenops is were found in the same nest. One worker of Pheidole morrisi was found in a nest of this Paratreching 
and several vorkers of arenivage were found in a nest of Pheidole morrisi. Since these ants usually live independently, it is likely that the workers had merely wandered into the foreign nests.

\section{Paratrochina parvula (Nayr)}

2. parrula and Pheidole dentata are perhaps the mast common ants on the Reservo. However, the ants listod under $P$. parrula in this paper ahow variation in the worker caste. Some aro of very palo coloration and amaller size, while others are darker and of larger 6ice. A majority of vorker are small in size and of lighter coloration; but some small, dark workers, and large, light workers were found. Moreover, the color of workerg within the same colony ye either pale straw with light brown bands on each segment of the gaster and with a dark hoad, or the gaeter and head may bo dark brom with tho thorex and logs only slightly lighter. Some of the variation in color is due to the ohange from the callow condition to the full color condition. Some of the dark vorkers, as well as 30 mo callow, have a distended gaster. Under both of these circumatances the workers have a lighter appearance than they would in their mare, undistended condition.

The me genitalia of the lighter colored form are insignificantly different from the darker form (the former are olightly emaller, but have the same configuration). Wesson and Wesson (1940,200) have found similar variation in parvula in southcentral Ohio. "Our material shows considerablo variation which we have been unable to refer to any but this epecies on comparien with material in the wheoler collection at the luseum of Comparative Z0ology, Hervard University. Specimens from wooded places are usually dark brown or black and hare $\mathrm{fer}$ or no halrs on the antennal 
scapos. They agreo with the typical perrula. Specimens from dry or exposed situations, on the other hand, are usually paler and have a variable number of hairs on the antennal scapes.....we have occasionally found colonies in which some of the workers bore a variable number of hairs on the entennal scapes while others bore none, ouggesting that this charecter may not ontirely reliable." specimens from the Reserve agree with those from Ohio in that the number of hairs on the anteanel scape is variablo. If all of the forms represent one spocios, it is possiblo, as the abore quotation suggests, that the drior nesting oites will contain lighter forms. But both light and dark form have boen taken from alnost erery atation on the Reserve, elthough the lighter forms are more prevalent in the higher, drier areas. Conversely, the larger sized vorkere are found in the wot areas.

In general $P$. parvula seems to prefer the wetter area, although nests have boon found in all of tho stations. It was taken abundantly in black pine-fetterbush flatwoods, mesic hamock, and marsh; commonly to abundantly in Plumer slash pino Platwoods; commonly in turkey oak, Loon scrubby Platwoode, longleaf pine flatwoods, Rutloge slash pino flatroods, xeric hamook, hydric hamock, and bayhoed; occasionally to comonly in scrub, Pomollo scrubby Platwoods, and river swamp; and occasionally in bluejack oak.

Throo-fourths of the rocords of parrula were made from the surface stratum. Approximately oqual numbers of collections vore made from under cover in sand and from nosts in the grass stratum. A for nests were taken arboreally.

Nosting sites of perrula, in order of preference, ares 


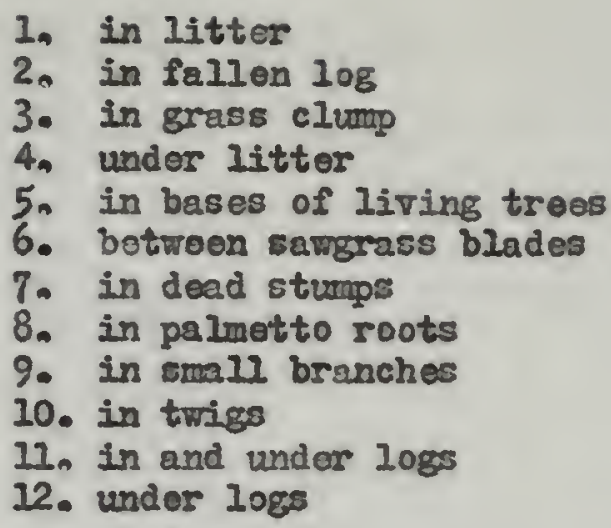

Nosts have been in wood varying from wet to dry, and from the first stages to the last atages of decay. They have been found under bark, in both broadloared and pine wood.

Most of the nests in sawgrass are between the growing, appresed blades, although some are in the dark sturups of savgrass which are wet or soturated. In the living samgrass, tho ants are able to Ifre at or neer the water surface. Several nests were found sightly below the water surface, within the plant parts which excluded the water. No nests were found very far from the wher lovel, since the blados diverge leaving no place to nest at a hoight of a fow inches; these higher portions of the plants aro also exposed to much greater eraporation than the partially shaded areas nesr the water. In January, the sangrass is for the most part dead, except for the inside blades, and the outer blades fall olightly apart. During this period, oven though the temperature is clenent, the ants are relatively scaree in marsh.

A similar shifting is notod for nosto in grass cluaps. Beginning in October the grass clumps in which the ants have lived during the sumer become dry and completely dead above the soll surface. With the dryings out of the grass above the surface, the donsity of the population in this nesting site decreases. Those ants that rouin inhabit the root systems 
of the grass; the others find litter or logs with suitable moisture. It is possible that during the rainy sumear the ants move their nests inte the above-ground, higher portions of the grass to avoid supersaturation, and that vith the onset of winter and dry weather, with the consequent drying of the gress, the ants move down into the moist lower sters and roots.

The number of individuals in tho nests of perrulg ranged, in the 4 nests counted, from 25 to 72 , areraging 45 . Fenales have been taken in nests as early as late July, and as late as the latter part of January. Males were found in Septomber through the last part of robruary. Winged form are most abundant in the neste in October, November, and December. The presence of winged forms during most months is noteworthy. This moderately fast moving ant is attracted to liver and molasses. Workers of parrula forage actively at night. It has beon found assooiated with the following insectsa

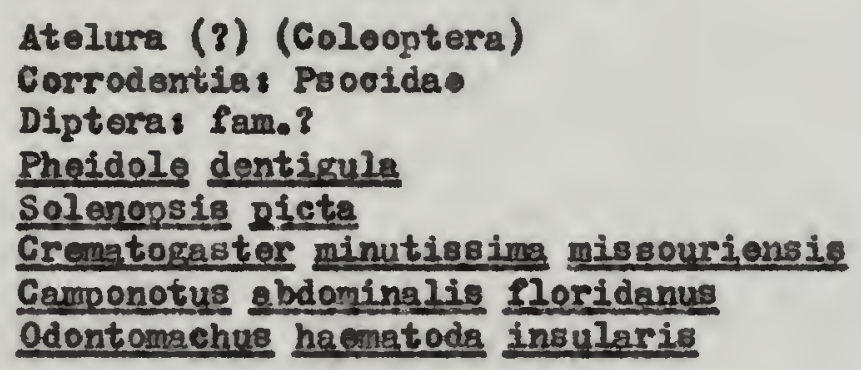

\section{Prenolenis imparis (Say)}

P. imparis has been taken in only two plant associations. These are turkey oak, in which it found rarely, and sorub, in which it was found occasionally. Occasional nests can be found on lawns in ruderal areas, and suggest that this yo an important nesting siturtion for the ant. In the Gainesvillo region, P. imparis was found occalonally 
in mesio hanock and ruderal areas, and was also taken in turkey oak and Slatwoods.

All of the nests on the Reserve were under litter, oven those in the ruderal areas. Those in Gainesville, however, nearly all formed complete craters in open areas. Both Grogg $(1944,470)$ and Colo $(1940,67)$ note that the ant builds craters and that it liver in clay. Cole otates that "The ante nest in shaded, molet, compact soil, particularly clay, occasionally boneath wood or stones; but more often construct obsoure crater mounds consisting of pellets of soil seattered around the singlo nest entrance." This last type of nest is found undor light litter on the Reserve. A neot was observod in which all of the ants ware duming sand peilats at least a foot from the nest oponing, in the process of excavation.

P. imparis moves with only moderate degreo of speod. It bocomes most active during cloudy or overcast days. Yolasses and corn bait for manal traps will attract it. Talbot (1943a and 1943b) and woeler (1930) have made extensive studies on R. inmaris, in regard to population and roeponse to environment.

\section{Eormice archboldj L. R. Smith}

I. archboldi was found in six plant associations. It was taken occasionally to comonly in turkey ark and black pine fetterbush flatwoods; occasionally in longleaf and Plumer slash pine flatwoods, and rarely in Rutlege slash pine flatwoods and xoric hamock. This distribution indicates that I. archboldi is attracted to areas of pine growth, more, it would seen, bocause of the lack of hoary leal litter than because of the pines. It has been found to be the most comon Formics on the Reserve. 
It has always boen found in the subtorranean stratum, and eithor in the sand under a log or under littor. Of tho 2 nosts counted, ono uncer a $\mathrm{log}$ in black pino-fetterbush flatwoods containod 63 workers, and 4 callows, in addition to oggs, 21 larvao, 18 pupao, and 20 pupal coooons. The other nost in turkey oak, taken under litter, contrined 222 workers, with eggs, 25 Iarvae, 6 worker pupae, and 21 pupal cocoons. This last nest also had 7 fomalo pupae, 3 ferale callow, and 20 femleo. Each nest had a quoen.

The first nest was within one loot of the surfaco, just above the water table. It containod many heads of odontomachus hacenatoda insularis, indicating that the Rermica uny take over Odontomachus nests, cr that the Odontomachus is used as food. The socond nost was 8 to 12 inches bolow the surface of the soil with a $1 / 4$ inch passageway loading to the ohambers. The castes and immaturo form socmed to bo erranged in order from top to bottom of the nest in the following ordury winged femelos; larvae and oggs; pupae; cocoons of workers; and cocoons of winged forms. It should bo noted that pupae are both nude and oovered with coooons.

I. archboldi usually moves with considerable spesd in most of the months of the year, but colloctions indicate that there is a period of ingetivity in the wintor months. Specimens have been taken with a spocies of soll mite (Hepoaspis 3 ) on the gaster directly bohind the petiole. In one nest the cricket Lrrmeophila pergandei Bruner (det. Cantrall) was found. 
Formice pollidefulve Letreillo

F. palifidefulve was found on the Reserve in only three plant 2ssociations. It was taken occasionaly in turkey oak and xoric hammook, and rarely in Pomello scrubby Platwoods. Theso situations have in comon their openness, and abeonce of thiek litter.

All nests of this epoeies wero found in the subterranoan otratum, all under cover of litter. It has also boen collected in Gainesville in this same sort of nesting sito.

One nest of $\mathbf{E}$. paliidefulve in turkoy oak had two openings, ono of which lod for only a short distence. The min opening lod laterally, at a depth of about $1 / 2$ inoh, for about 3 inches where there a chamber, then straight down to whore tho passageway stopped at 3 foot. Blind passageways, and chambers wero spaced along the downward passage. At 3 foot workers of Camponotus socius woro oncountored, and were seen carrying cocoons. No oggs, larvae, or pupte, other than thoso carriod by the Camponotus were observed.

Like the other Eormica of the Reserve, this ant could usually bo soen moving with considerable spoed in ite foraging activities.

\section{Formica schaufussi Hayr}

On the Reserve E. sohaufusei was found rerely in turisey wak and longleat pine flatwoods. In Gainesville it was pound in xeric haumook and an open rudoral area.

Nosts on the Reserve vere all in the subterranean stratum and under litter. About this ant, Cole (1940:79) writoss mibe ants 11 ve in the ground, as a rule benesth stones in opon, warm, rather dry grassy arcas. A few obseure crater mounds were found, and a number of colonies 
which nested beneath stonos had adjoining earthen craters. Tho stones were loosely banked along their margins with soil particles. Underneath was a number of large, irregular superficial chombers, but the main part of the nest was at a depth of $11 / 2$ to 2 lest underground. The colonies aro as a rule, populous, and the workers aro agilo and timid when disturbed." These remarks agreo with, and add to, the observations mende on the Wolaka Reserve. 


\section{Addends}

Leptogenys elongatö manni thooler

On July 26, 1950 , a specimen of this Ponerine ant was collected in river swamp. The swamp at the time of collection was extremely dry, and the ant was crawling over litter that oontained vory littlo moisture. In the Gainesville rogion it was taken in mesic hamock from rotting stums.

The occurrence of this Leptogenre on the Reserve will affect

Figures 3 and 5, but these ligures will be altered to only a slight extent. 


\section{SURAARY}

The present study dealo with ocologicel relationships of the ants of the University of Florida Conservation Reserve, a 2180 acre tract in northeastern peninsular Florida. Field work was carried on from October, 1947, until June, 1950. Serenteen collocting trips vere made to each of fifteen areas or stations (plant association-soil type combinations) chosen to represent the major regetational and ooil variations of the Reserve.

Seventy-one species and subspecies of ants were taken on the Reserve, and four others were collected in nearby towns. Fourteon ant forms were recorded for the first time from the state.

Quantitative relationships were doterminod for the ant forms within the stations, by using the colony, and not the individual ant, as the biological unit. Assemblages of ants which were characteristic and distinctive qualitatively and/or quantitatively were found to oxist in the stations, and in four strata and sixteon nesting sites within the stations. The environments of each of these assemblages were therefore designated ant habitats.

For the Reserve, Pheidole dentate showed the greatest abundance; the next four forms in order are:

\section{Paratrechina pervula}

Camponotus abdominalis flóridanus

Odontomachus haomatoda insularis

Solonopsis molosta

In both variety of ant forms and number of nests, the turkey oak and xeric hamock stations rank well above all others, whereas the slash pine flatwoods, river swarm, and marsh stations rank at the bottom. This indicates that the higher, drier stations aro more suitable for 
ants than the lower, wotter areas.

There were 14 forms none of which were collected from more than one station, while each of 3 forms were found in all 15 stations. Figure 5 shows the relationship between the number of ant forms and the numbers of stations. When the ants wich were collected only once aro omitted, then there vere only 5 forms none of which were collected from more than one station. From this and other evidence it seems probable that ants do not show as much dependence on plant aseociation-roil type combinations as do other animals.

Diatribution in strata and nesting sites showed that ants proferred the subterranean and surface strata, and within these strata, nests in sand, fallon $10 \mathrm{~g} 8$, or stumps. Only nineteon forms nested in the herbecoous and arborcal atrata.

A correlation is shown between the number of nesting sites a form occupies and the number of stations it occuples. In general, howerer, the number of stations occupied increases faster than the number of nesting sites occupied. From this it vould seem that many ants are more restricted by nosting sites than by plant associationoil typo combinations.

Data concerning the ife histories, activity, food, and habits in general have boen brought togother under the appropriate ant form in the Annotated List. Indications of variations in seasonal occurrence hare been apparent for only a fer forms, and in all cases have boen due to the seasonal variability in abundance of the suitable nesting sites. The ant forms on the Reserve vary greatly in the time and physical conditions under which thoy forage. Soveral forms havo a wide range in this respect. 
It was also observod that the individuals of cortain ant forms appear darker in color when they nest in the open areas of tho Reserve, whereas other ante are darker in the ohadod areas; and that the individuals of cortain forms are larger in the wetter areas than in the higher, drier areas. 


\section{Acknoricledgments}

Thanks are due Dr. M. R. Smith of the U. S. Nationel Musoum for hie interest and determinations throughout tho study. Mr. W. L. Brown, Jr. of the Harvard Biological Laboratories, for his aid with the identification of spocimens of Smithistruma, and Dr. N. S. Creighton of the City College of New York, for his help with certain problems arising in connection with the subgenus Diplorhoptrum of the genus Solenopsis, deserve many thanks. Acknowlodgment is due Dr. Lowis Berner and Dr. H. K. Wallace, both of the Blology Dopartment of the University of Florida, for their eriticism and help with the manuscript. Many thanks are also due Rusty Van PeIt for typing the final manuscript. 


\section{LITERATURE GITED}

Brown, W. L., Jr.

1948. A Preliminary Generic Revision of the Higher Dacetini. Trans. Amer. Ent. Soc. 74 : 101-129.

1949. A New American Amblyopone, with Notes on the Genus. Psyche 56 (2): 81-88.

Buren, Wm. 5 .

2944. A List of Iowa Ants. Iow Stato Colloge Jour. Sci. 18. $277-312$.

Cantrall, I. J.

1943. The Ecology of the Orthoptera and Dermaptera of the George Reserve, Kichigan. Hisc. Pub, Mus, Z001. Univ. Kichigan, no. 54.

Colo, A. C., Jr.

1932. The Relation of the Ant, Pogonomyrmex occidentalio Cr., to its Habitat. Ohio Jour. Sci. 32 (2), 133-146.

1940. A Guide to the Ants of the Great Smoky Hountain National Park, Tonnesser. Amer. Hid. Nat. 248 1-88.

Cooke, C. Wythe

1945. Geology of Florida. State of Florida Dept. of Cons., Gool. Bull. 29.

Creighton, Wm. s.

1938. On Formicid Nomenclature. Jour. N. Y. Ent. Soc. 46: 1-9.

1950. The Ants of North America. Bull. Mus. Comp. 8001. 104: $1-585$. 
Dennis, C. A.

1938. The Distribution of Ant Species in Tennesseo, with Reference to Ecologicel Factors. Ann. Dat. Soc. Amer. 31, 267-308.

Enery, $C$.

1895. Beitrage zur Kentnio der nordamerikanischon Ameisenfauna. Zool. Jahrb. Syst. 8: 257-360.

Gregs, R. I.

1944. The Antr of the Chicago Rogion. Ann. Fnt. Soc. Amer. 37: $447-480$

Haskins, C. P.

1928. Notes on the Behavior and Habite of Stimatomes pelipes Ha1d. Jour. N. Y. Ent. Soc. $36: 179-184$.

Hayes, Win. P.

1920. Solonopsis polorta Say: A Blological Study. Kansas Tooh. Bull. 7: 7-55.

Hubbell, T. H. and C. C. Gorf

1939. Florlds Pooket-Gophor Burrows and thoir Arthropod

Inhabitants. Pros. Fla. Acad. Se1. 4, 127-166.

Leessle, A. $\mathbf{H}$.

1942. The Plant Comunities of the Wolaka Area. Univ. of Fla. Pub., Biol. Sci. Ser. 4 (1): 1-143.

Mitehe21, A. J. and U. R. Ensign

1928. The Climate of Florida. Unir. of Fla. Agr. Expt. Sta. Bu11. 200: 1-300.

Swith, U. R.

1930a. Another Imported Ant. Fla. Ent. 14: 23-24.

1930b. A thist of Florida Ants. Fla. Ent. 14 1-6. 
1933. Additional Speoies of Floride Ants, with Remarks. Fla. Ent. 17, 21-27.

1934. Ponerine Ants of the Genus Buponere in the U. S. Ann. Ent. Soc. $278557-564$.

1936. Ants of the Genus Penera in Americs North of Mexico. Ann. Fnt. Soc. Amer. 29 s 420-430.

1942. A Now North American Solenopsis (Diplorhoptrum). Proc. Ent. Soc. Wash. 448 209-212.

1944a. Additional Ants Recorded from Florida, with Descriptions of Two New Subspocies. Fle. Ent. 27: 14-17.

1944b. Ants of the Genus Cardiocondris Mnory in the U. S. Proc. Ent. Soc. Wash. 46:30-41.

Talbot, Hary

1934. Distribution of Ant Spocies in the Chicago Area, with Refecence to Ecological Factors and Physiological Tolerance. ICology $15,416-439$.

1943a. Reeponse of the Ant Prenolepis imparis Say to Temperature and Humidity Changes. Ecology 24s 345-352.

2943b. Population Studies of tho Ant Prenolepis imparis Say. Ecology 24; 31-45.

Treat, Nary

1878. The Harresting Ant of Florida. Harper's Nev Monthly Kagazine. New York.

Van Polt, A. $r$.

1948. A Proliminary Koy to tho Korker Ants of Alachus County, Florida. Fla, Int. $30,57-67$. 
Fosson, L. G., Jr. and R. G. Wesson

1940. A Collection of Ants from Southcontral Ohio. Amer. Hid. Mat. 24, 89-103.

Wost, Erdmon and LAllian Arnold

1946. The Rative Trees of Florida. Univ. of Fla. Press, Gainesville, 212 pp.

Wheeler, Vh. น.

1904. The Amorican Ants of the Subgenus Colobopis. Bull. Amor. Hus. Nat. Hist. 20, 139-158.

1905. An Annotated List of the Ants of New Jersey. Bull. Amer. Mus, Nat. Hist. 21: 371-403.

1910. Ants, their Structure, Dovelopment and Behavior. Columbia Univorsity Pross, 663 pp.

1930. The Ant Prenolopis imoaris Say. Ann. Int. Soc. Aner. 238 $1-26$.

1932. A List of the Ants of Floride with Descriptions of Ner Forws. N. Y. Ent, Soc. Jour. $40,1-17$.

Wray, D. L.

1938. Notes on the Southern Harvester Ant (Pogonomormex bedius Latr.) in North Carolina. Ann. Ente. Soc. Amer. 31: 196-200. 


\section{BIOSRAPHICAL ITEIS}

Arnold Francis Van Pelt, Jr. born Septuber 24, 1924, in Orange, New Jersey. He carried cut his undergraduate studios at Swarthmore Colloge, where he obteinod the degreo of Bachelor of Arts in October, 2945. In 1947, he recoived a dogreo of llaster of Science from the Univergity of Florida, where he hold a graduate asaiotantship from the fall of 1946 to the spring of 1948. From the fall of 2948 until the fall of 1950 , he rocoived a graduate followship from the Univeraity. He is a member of Phi S1gma honorary biologicel society. 
This dissertation was prepared under the direction of the Chairman of the candidato's Supervisory Comaitteo and has been approved by alI members of the Committeo. It was submitted to the Graduate Council and was approved as partial fulfilment of the requirements for the degree of Doctor of Philosophy.

September 2, 1950

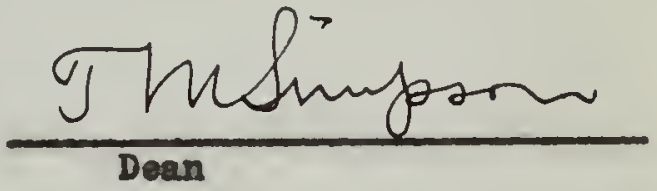

SUPERVISORY COLAITISEE:
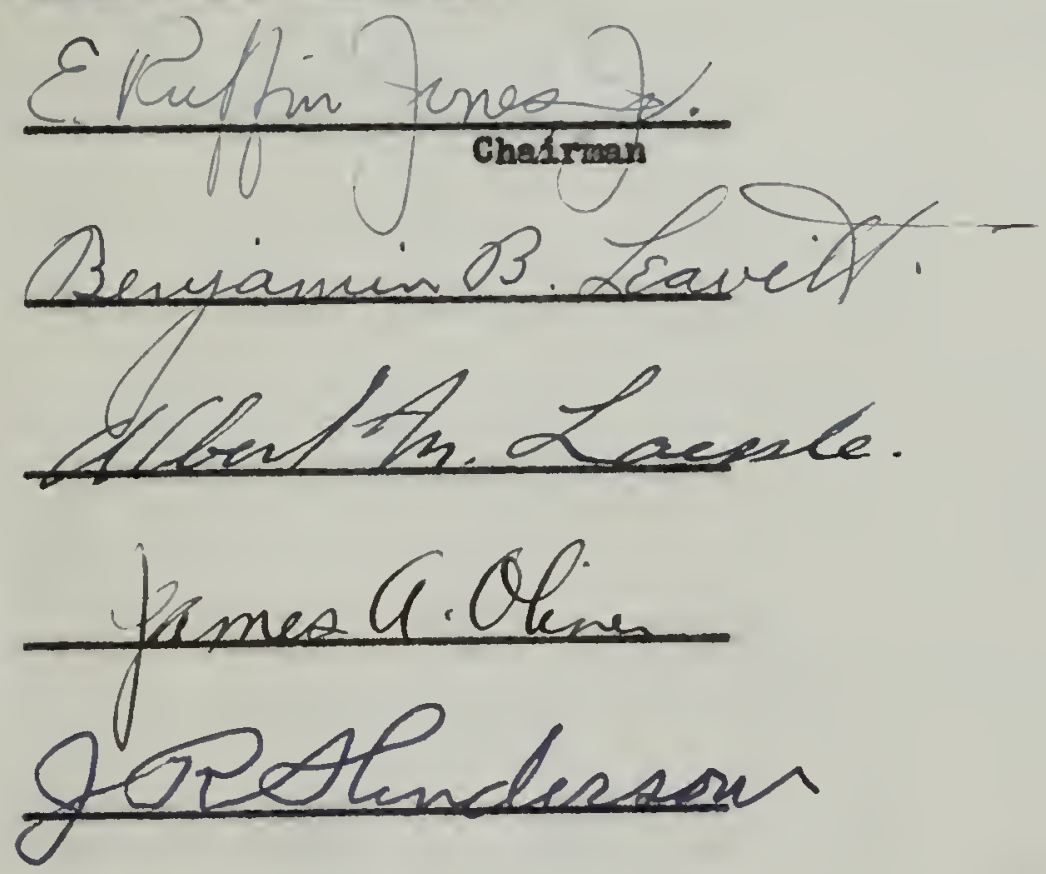
,,$\cdots$, 
